UNIVERSIDADE DE SÃO PAULO

ESCOLA DE COMUNICAÇÕES E ARTES

IANA COSSOY PARO

\title{
Escrever o som: busca pelo espaço do sonoro em roteiros audiovisuais
}

SÃO PAULO

2016 
IANA COSSOY PARO

Escrever o som: busca pelo espaço do sonoro em roteiros audiovisuais

Dissertação apresentada ao Programa de Pós-Graduação em Meios e Processos Audiovisuais, na Linha de Pesquisa: Poéticas e Técnicas, como requisito parcial para obtenção do título de Mestre em Meios e Processos Audiovisuais.

Orientador: Prof. Dr. Eduardo Simões dos Santos Mendes

SÃO PAULO

2016 
Paro, Iana Cossoy

Escrever o som: busca pelo espaço do sonoro em roteiros audiovisuais. 2016: 116 p.

Dissertação (Mestrado em Meios e Processos Audiovisuais)

Universidade de São Paulo,

Programa de Pós-Graduação em Meios e Processos Audiovisuais

Escola de Comunicações e Artes, São Paulo, 2016.

Orientador: Prof. Dr. Eduardo Simões dos Santos Mendes.

1. roteiro cinematográfico 2. som 3. narrativa audiovisual 4. processos criativos. 
Nome: PARO, Iana Cossoy

Título: Escrever o som: busca pelo espaço do sonoro em roteiros audiovisuais

Dissertação apresentada ao Programa de Pós-Graduação em Meios e Processos Audiovisuais, na Linha de Pesquisa: Poéticas e Técnicas, como requisito parcial para obtenção do título de Mestre em Meios e Processos Audiovisuais.

Aprovado em:

Banca Examinadora

Prof. Dr.

Instituição:

Julgamento:

Assinatura:

Prof. Dr. Instituição:

Julgamento:

Assinatura:

Prof. Dr. Instituição:

Julgamento: Assinatura: 


\section{AGRADECIMENTOS}

Este trabalho é em grande parte fruto da minha experiência como aluna da Escuela Internacional de Cine y Televisión de San Antonio de los Baños - EICTV, formada por seus fundadores, trabalhadores, alunos e professores. Agradeço especialmente a meus maestros Eliseo Altunaga Barreras e Jeronimo Labrada Hernandez, os primeiros que me estimularam a pensar sobre o som dentro do processo de escrita de roteiros audiovisuais.

Agradeço também ao Programa de Pós Graduação em Meios e Processos Audiovisuais da Escola de Comunicações e Artes da Universidade de São Paulo, especialmente à dedicação do meu orientador Eduardo Simões dos Santos Mendes.

E por toda a força e incentivo aos meus pais, Thais Cossoy Paro e Vitor Henrique Paro. 
Acredito que cada um de nós inventa algo que nos permita duvidar da realidade, tão contundente, na qual nos educaram. Que nos permita encontrar as brechas. E em geral nos afirmamos sobre um dos sentidos. Acho que a visão nos engana, porque dirigimos ao olhar ao futuro e as costas para o passado. A flecha do tempo sai dos olhos. Então o presente é o corpo, este é o único atrativo dessa teoria, mas não é só isso. Para mim, minha muleta, minha cadeira de rodas, é o som. Ele te obriga a um esquema de tempo onde a flecha deixa de ter um sentido. $\mathrm{O}$ objeto que emite som o faz em todas as direções e o sujeito o recebe com todo seu corpo, não só com os ouvidos. Obriga a pensar em um sujeito mais atento que aquele que se impõe sobre os objetos com o seu olhar. Em um esquema que mostra uma pessoa olhando, a flecha vai do sujeito ao objeto; por outro lado, quando o esquema tenta representar a escuta, a flecha vai do objeto ao sujeito. Gosto desse sujeito mais submisso, em um tempo mais ajustado a sua memória, a seus desejos de futuro, mas sem a ordem maligna da linha, do sentido unívoco.

Lucrecia Martel (VALDES, 2016, tradução minha) 


\section{Resumo}

\section{Escrever o som: busca pelo espaço do sonoro em roteiros audiovisuais}

Esta dissertação busca investigar processos de escrita audiovisual em que a trilha sonora é um elemento narrativo e dramático construído a partir do roteiro. A pesquisa teórica baseia-se na análise de manuais de roteiro e em guias sobre som no audiovisual. O objetivo desta análise é encontrar as circunstâncias em que a trilha sonora é considerada elemento integrante do processo de escrita de obras audiovisuais. Nossa principal questão é se existem regras e padrões para uma produção de textos que estabeleçam a função do som desde o processo criativo inicial da composição de uma obra audiovisual, considerando a dialética som-imagem. A pesquisa empírica tem como base a leitura analítica de roteiros de filmagem de diferentes autores, visando entender como se descreve ou enuncia a banda sonora em cada um deles. Considerando que roteiros não são a obra final, os escritos analisados são comparados com os filmes já prontos. Nosso objetivo é, por meio desta pesquisa, colaborar para o instrumental teórico e prático a que um roteirista pode recorrer no momento de desenvolvimento de um relato cinematográfico ou audiovisual.

Palavras chave: 1. roteiro cinematográfico 2. som 3. narrativa audiovisual 4. processos criativos. 


\section{Abstract \\ Writting sound: search for sound's space inside movie scripts}

The aim of this research is to investigate screenwriting processes in which the soundtrack is a narrative and dramatic element built from the script. The theoretical research is based on an analysis of script manuals and guides about sound in the audiovisual media. The objective of this analysis is to find the circumstances in which the soundtrack is considered an integral element of the writing process of audiovisual works. Our main question is whether there are rules and standards for the production of texts that establish the function of the sound from the initial creative process of composition of an audiovisual work, considering the dialectics sound-image. Empirical research is based on the analytical reading of scripts by different authors, in order to understand how each of them describes or announces the soundtrack. Whereas scripts are not the final work, scripts are compared with the films. Our goal is, through this research, to contribute to the theoretical and practical resources that a writer can refer to when developing a cinematographic or audiovisual story.

Keywords: 1. Movie scripts 2. Sound 3. Audiovisual narrative 4. Creative process 


\section{SUMÁRIO}

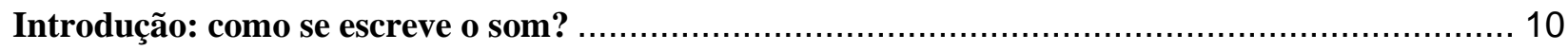

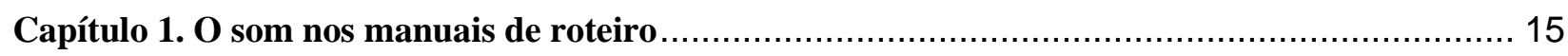

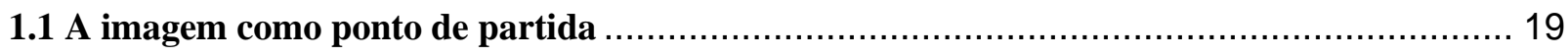

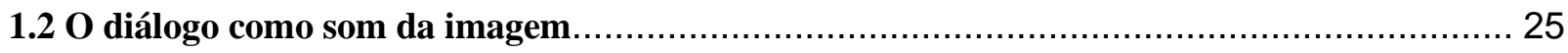

1.30 resto do som: presença de componentes da trilha sonora nos manuais ......................... 27

1.4 A música como metáfora para estruturar a escrita .......................................... 33

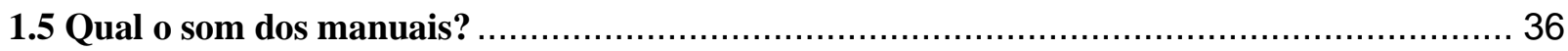

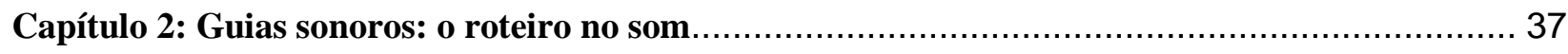

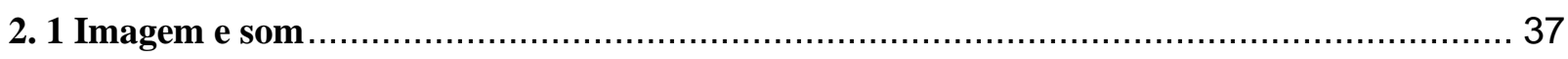

2.2 O roteiro como ferramenta de trabalho: quando e onde o filme começa a soar? ............... 42

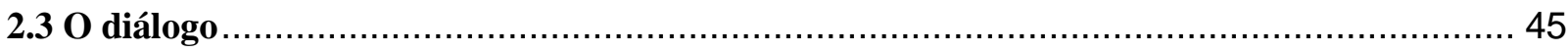

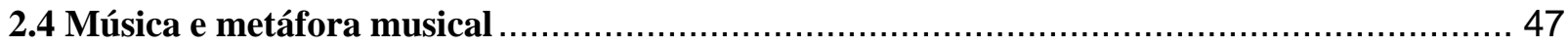

2.5 Qual a função do objeto roteiro? Como se escrevem as indicações sonoras? ..................... 49

Capítulo 3: Análises da possibilidade de escrita do som em sequências de roteiros................... 54

3.1 Escrita invisível e o som no roteiro "padrão" ................................................... 58

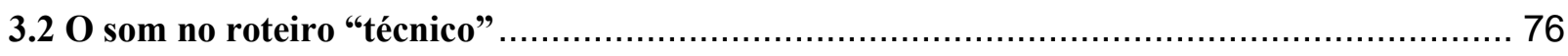

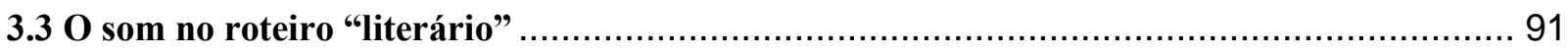

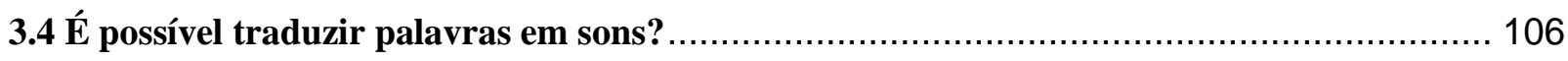

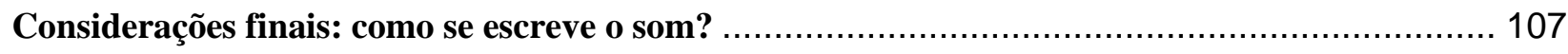

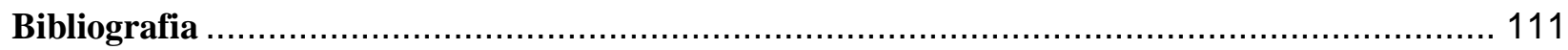




\section{Introdução: como se escreve o som?}

Em 2009, escutei Lucrecia Martel, em conferência na Casa de América (Madri), falar sobre a abordagem do som em seus filmes. A realizadora argentina lembrou como estamos imersos em sons, mas somos educados para guiar-nos pelos olhos, pela imagem, e que o cinema, como outros relatos que escutamos desde a infância, pode ser construído a partir do som.

Em meu trabalho como roteirista, a questão da tradução de imagens e principalmente sons em palavras já me intrigava havia bastante tempo. Tomando como base a reflexão sugerida por Martel, passei a analisar como se articulam sons, imagens e ações para criar a trilha sonora de um filme desde o roteiro, além de abrir possibilidades para que esses sons se desenvolvam e se ampliem ao longo das etapas de filmagem e pós produção. Considerei, ao longo desta dissertação, a definição de que "a trilha sonora de um filme é composta de vozes, ruídos, ambientes e músicas" (FLÔRES, 2013, p. 30) .

O objeto de estudo desta dissertação é o roteiro audiovisual, analisado a partir de suas características sonoras. Entendo roteiro audiovisual como objeto mais próximo do som e da imagem que da literatura: é um relato que funciona como instrumento de transição entre a história e o filme. Compartilho da concepção do escritor e roteirista cubano Eliseo Altunaga Barreras, segundo o qual "os filmes não se escrevem” (BARRERAS, 2013, p. 1) e os roteiros servem para

construir, com palavras que indicam espaços, tempos, ações, imagens e sons, aquilo que é consubstancial ao relato. As referências ao som no roteiro, por outro lado, muitas vezes fazem parte de sua "escrita invisível” (CARRIERE; BONITZER, 1998, p. 42), ou seja, tentam ocultar indicações técnicas.

A principal pergunta com relação a este objeto é: como é possível escrever uma trilha sonora narrativa e dramaticamente significativa a partir do desenvolvimento do roteiro audiovisual, das palavras escritas no papel? Vale ressaltar que o importante aqui é a análise do processo de escrita do roteiro e suas consequências no produto final, ou seja, o filme finalizado. Até que ponto a criação de uma trilha sonora expressiva passa por técnicas e recursos de escrita do roteiro? Existe um tipo de escrita que favoreça o som? O esforço para "pensar em como soa a 
nossa história, sobre o que escutam os personagens e em como o som influi em suas ações e emoções, como na vida" (LABRADA, 2009; p. 52, tradução minha) tem início necessariamente no roteiro?

Esta dissertação tem como principal intenção investigar como é possível escrever roteiros em que o som é um elemento narrativo e dramático, e não apenas um complemento ou agente corroborador ou homogeneizador da imagem que ajuda a "estabelecer a 'relação intersubjetiva' entre o filme e o espectador" (DOANE, 1991, p. 467).

Ao estudar o universo sonoro a partir das primeiras etapas da elaboração de um filme de ficção narrativo (o roteiro e suas partes; cena e sequência, descrições, diálogos, rubricas), pretendemos expor o papel dos recursos sonoros possíveis na dramaturgia escrita para transformar-se em obra audiovisual. Como recursos sonoros entendemos vozes, ruídos, efeitos e músicas (diegéticos ou extradiegéticos) que afetam, segundo David Bordwell e Kristin Thompson (1985, p. 181-199), volume, ritmo, tempo (de projeção e do relato) e espaço fílmicos.

Se já existe certa carência em estudos sobre o som cinematográfico em relação aos estudos sobre a imagem, quando se trata de estudos sobre o som relacionado ao roteiro a carência é ainda maior. Grande parte da bibliografia teórica e dos manuais aborda o roteiro principalmente a partir da imagem. O presente trabalho se localiza na intersecção entre duas áreas do estudo acadêmico cinematográfico: som e roteiro. Por isso, buscamos na teoria sobre roteiro e na teoria sobre o som recursos que possam contribuir para a elaboração de uma escrita sonora.

O som é uma ferramenta essencial na construção de climas, tensões, emoções. Trata-se de um recurso narrativo assim como as ações dos personagens, por exemplo. No entanto, é raro que o som-narrativo esteja indicado no roteiro. São poucos os roteiristas que escrevem o som. Na América Latina, temos o exemplo já citado de Lucrecia Martel, cujas obras são objeto de análise de alguns trabalhos acadêmicos. Meu intuito é entender como o som é escrito e se existe uma relação entre a ruptura (ou releitura) da forma convencional da escrita dos roteiros e a presença de roteiros mais sonoros.

Se o cinema nasceu "mudo", ou silencioso, ele sempre supôs a existência do som e o buscou, seja por meio da montagem, das cartelas de diálogos ou da música e ruídos usados para 
acompanhar a apresentação dos filmes, ou por meio da própria imagem. Se é verdade que muitas vezes se usa vocabulário relacionado à imagem para descrever sons - sons claros, velados, brilhantes ou transparentes - é igualmente certo que o cinema, ao apropriar-se de recursos de diferentes áreas e artes como literatura, pintura e fotografia apropria-se também de recursos da música e do som para constituir suas formas. Além disso, há termos usados em audiovisual que não pertencem nem à esfera do som, nem à da imagem, mas remetem a ambas ou a nenhuma, como é o caso de ritmo: "Ritmo, por exemplo é um elemento do vocabulário cinematográfico que não é nem uma coisa nem outra: nem especificamente audível, nem visual", afirma Michel Chion (1990, p. 135).

A intenção deste estudo não é isolar a presença sonora no roteiro, uma vez que imagem e som estão dialeticamente relacionados, nem adotar uma definição essencialmente visual do cinema, na qual o universo sonoro é um suplemento. Ao abordar a poética sonora dos filmes, discordamos da "concepção preconceituosa de uma suposta natureza visual do cinema" (MACHADO, 1997, p. 153). A ideia desta dissertação, no entanto, não é questionar se o cinema é uma arte predominantemente imagética, mas ir ao roteiro para tentar entender como o som pode ser um agente tão importante quanto a imagem, atuando junto a ela, chegando à "dicotomia que não reside na oposição, mas na identidade som-imagem" (BURCH, 1992, p. 117).

Nesta dissertação, sigo o percurso de análise dos manuais de roteiro aos "manuais" de som e aos roteiros em si, para entender se a forma como os roteiros são escritos interfere em seu conteúdo sonoro e se os casos de roteiros mais "sonoros" estão ligados a certo "desrespeito" às regras de escrita. Este estudo identifica e analisa métodos de escrita da trilha sonora no audiovisual, com o intuito de organizar e ampliar o instrumental a que o roteirista pode recorrer no momento de desenvolvimento de um relato cinematográfico. A partir dos dados coletados e analisados, o objetivo é responder a quatro perguntas principais: a) Como tecnicamente se escreve o som? b) Existe um padrão para a escrita da trilha sonora em roteiros audiovisuais? c) Qual o papel narrativo e expressivo do som no cinema de ficção narrativo contemporâneo? d) Até que ponto um som indispensável na compreensão de uma narrativa pode ou precisa ser pensado desde o roteiro?

O Capítulo 1 faz uma análise das técnicas de escritura audiovisual, sistematizadas em 14 manuais de roteiro, e suas consequências para a escrita do som. Até que ponto, nos manuais e 
guias para a elaboração de roteiros, o som é previsto como elemento narrativo interdependente da imagem? Ao longo do capítulo, identificaremos como os manuais muitas vezes propõem soluções em que o som é apenas um efeito técnico, e a imagem na maioria das vezes é o único ponto de partida. Analisamos a forma do roteiro e as instâncias em que a música aparece como metáfora para explicar estrutura, ritmo, etc. Além disso, veremos como na maioria das manuais o "par" da imagem é o diálogo, não o som em geral, e até que ponto os efeitos e sons em off são levados em conta por esses textos. Para terminar o capítulo, avaliaremos como o conceito de trilha sonora é abordado nesses manuais.

No Capítulo 2, a intenção é fazer o caminho "contrário" ao do Capítulo 1, procurando avaliar como autores que pesquisam o papel do som no cinema abordam o roteiro. A escrita do roteiro é levada em conta por aqueles que pensam na composição e criação dos elementos sonoros das obras audiovisuais? Feita esta primeira análise, o capítulo tem como segundo objetivo definir o que é um som narrativo, argumental ou dramático.

No Capítulo 3, serão feitas análises de sequências escritas em roteiros. Partimos do conceito de roteiro como estrutura transitória, elaborado por Pier Paolo Pasolini, e da ideia de "escrita invisível" estabelecida por Jean Claude Carrière e Pascal Bonitzer, segundo a qual as indicações técnicas de enquadramento, som, etc. estão "escondidas" ou implícitas no texto do roteiro literário. Tais conceitos nos ajudarão a situar o roteiro como objeto transitório entre ideia/argumento e o filme em si. Aqui tentamos entender se o rompimento das regras da escrita convencional, ou a busca de formas dentro da forma padrão geram uma escrita de roteiros mais sonora.

Em seguida, é apresentada uma variedade de sequências de roteiros que usam o som como elemento narrativo, em uma tentativa de identificar na forma escrita elementos que definem ou abrem espaço para o sonoro. Serão analisados alguns exemplos internacionais: Amor (2012, escrito e dirigido por Michael Haneke), Barton Fink (1991, escrito e dirigido por Ethan Coen e Joel Coen), O Pântano (2001, escrito e dirigido por Lucrecia Martel) e filmes brasileiros São Paulo Sociedade Anônima (1965, escrito e dirigido por Luís Sérgio Person), O céu de Suely (2006, escrito por Felipe Bragança, Maurício Zacharias e Karim Ainouz, que dirigiu o filme). $O$ bandido da luz vermelha (1968, escrito e dirigido por Rogério Sganzerla) e Girimunho (2011, escrito por Felipe Bragança e dirigido por Clarissa Campolina e Helvécio Marins). A pergunta 
que norteará esta etapa é: até que ponto as soluções sonoras com peso narrativo ou dramático são fruto do tipo de escrita audiovisual?

Nas considerações finais procurarei, levando em conta as análises teóricas e de sequências de filmes, estabelecer quais as possibilidades e ferramentas que um roteirista tem para construir, com o seu trabalho, ideias que contribuam criativamente para a trilha sonora da obra audiovisual para a qual seu texto será traduzido. 


\title{
Capítulo 1. O som nos manuais de roteiro
}

\begin{abstract}
Quando comecei a fazer cinema, pensava que fosse uma linguagem de arte [...] e, portanto, me recolocaria, novamente, na minha experiência literária. À medida que fui trabalhando com o cinema, me dei conta de que não se tratava de uma técnica literária, mas de uma verdadeira língua [...] e aqui já se explica o motivo pelo qual continuei a fazer cinema e abandonei a literatura. (PASOLINI, 1982, p. 145 , tradução minha)
\end{abstract}

O primeiro passo para responder à pergunta “como se escreve o som?” é uma análise das técnicas de escrita audiovisual, sistematizadas em manuais de roteiro (aqui entendidos como os manuais em si, ou seja, os que se intitulam assim, e outros livros que se propõem a estabelecer regras, conselhos e diretrizes para a escritura de obra audiovisual).

Os manuais e livros de roteiro não são as únicas fontes à qual os roteiristas recorrem para escrever, mas de certa forma, ainda que generalizada, tais publicações sistematizam as práticas de escritura audiovisual. Existe, no cinema contemporâneo, uma tendência a certa "ênfase no roteiro", gerada pelos sistemas de distribuição de fundos, que costumam escolher os filmes a partir do relato escrito, ou seja, exigindo a apresentação de roteiros, como percebe Lucia Nagib. Segundo a autora,

Os novos cinemas recentes são sustentados por uma combinação de recursos nacionais e internacionais, derivados de patrocinadores públicos e privados, em casa, e agências de fundos, festivais e canais de TV, no exterior. Na maioria dos casos os fundos são concedidos após o roteiro do filme ser analisado e aprovado por comissões de especialistas. (NAGIB, 2007, p. 95, tradução minha)

Nagib identifica esse "boom de roteiros" também no chamado "cinema da retomada" no Brasil, que gerou uma proliferação de cursos de roteiro a partir de meados dos anos 1990. "Syd Field, 'o guru de todos os roteiristas', como a CNN uma vez o chamou, esteve no Brasil várias vezes, oferecendo palestras e oficinas, e seus livros foram publicados em português e tornaram-se moda." (NAGIB, 2007, p. 95-96)

Os manuais norte-americanos, principalmente os de Syd Field e Robert McKee, têm bastante influência no Brasil: o Manual do Roteiro, de Field, por exemplo, teve 14 edições no país. Ambos os autores ministraram palestras no país ao longo dos anos 1990 e começo dos 2000 
(McKee veio em 2010 e em 2014, e segundo sua página oficial mais de 55 mil pessoas em todo o mundo assistiram a seus seminários). Mais recentemente, o franco-argentino Miguel Machalski tem participado de palestras e laboratórios de roteiro no Brasil, onde também atua como consultor de roteiros. As obras escolhidas como material de estudo deste capítulo são manuais de roteiro que tiveram ou ainda têm grande circulação e são fonte bibliográfica de cursos de roteiro e de estudos sobre o tema.

Manual do Roteiro (1979), de Syd Field; Story (1986), de Robert McKee; Como aprimorar um bom roteiro (1987), de Linda Seger; Save the cat! The last book on screenwriting you'll ever need, de Blake Snider (2005); Script columns (1997), de Terry Rossio; Como se escreve um roteiro, de Michel Chion (1986), Técnicas de guión para cine y televisión; de Eugene Vale (1982); Práctica del guión cinematográfico (1998), de Pascal Bonitzer e Jean-Claude Carrière; Guiones modelo y modelos de guión (1991), de Francis Vanoye; e El guión cinematográfico: un viaje azaroso (2006), de Miguel Machalski.

Além dos manuais estrangeiros internacionalmente conhecidos, analisamos, neste capítulo, três manuais brasileiros: Roteiro (1983), de Doc Comparato, Manual de Roteiro (2004), de Nilton Cannito e Leandro Saraiva e Roteiro de Cinema e Televisão: a arte e a técnica de imaginar, perceber e narrar uma estória (2007), de Flavio de Campos.

Há, nos manuais de roteiro, consenso com relação ao fato de que um roteiro não é uma obra literária. Machalski afirma que é fundamental distinguir o roteirista do escritor de obras literárias, pois "se narra com a caneta de forma muito diferente que com a câmera, e cai sobre o roteirista a tarefa especializada de criar a ponte entre a caneta e a câmera, entre o papel e a tela" (MACHALSKI, 2006, p. 19). Em sua definição do que é um roteiro, o teórico francês Francis Vanoye também o situa entre a literatura e o cinema.

Não é o lugar da elaboração da escrita como podem ser o romance ou o teatro: as descrições e retratos só existem para a informação indispensável, devem ser eliminadas as considerações reflexivas, e o estilo narrativo está em seu grau zero. [...] Mas o roteiro também não é o filme: não implica verdadeiras imagens, nem efeitos de montagem perceptíveis, e isso sem falar dos sons e das vozes... (VANOYE,1996, p. 19, tradução minha) 
Assim, a definição de Vanoye relaciona o que é escrito no roteiro às etapas posteriores de produção de um filme, inclusive a captação, edição e mixagem de som. Para ele "o roteiro constitui um conjunto de propostas para a elaboração de um relato cinematográfico, propostas que interagem com as operações de filmagem, montagem, mixagem, etc." (VANOYE, 1996, p. 20). Essa visão se aproxima da função que estamos buscando para o instrumento roteiro nesta dissertação: a de um objeto de transição entre o argumento e o filme, que contém, além do relato, elementos diretos ou indiretos de composição de fotografia, trilha sonora, mise-en-scène e edição. O autor também chama atenção para a especificidade formal do texto do roteiro:

O roteiro é tudo o que se escreve antes, durante ou com vistas à elaboração de um filme. Mas o roteiro pode ser também, tanto no imaginário do público e dos profissionais como na prática, um tipo de texto que responde a regras precisas, a prescrições normativas [...]. (VANOYE 1996, p. 13-14, tradução minha)

Vanoye relaciona a atual forma do roteiro audiovisual à chegada do cinema sonoro, que "modifica a apresentação do script, no qual temos que integrar os diálogos, a menção aos ruídos e a música. Fica então comum o script cena a cena (e já não plano a plano).” (VANOYE, 1996, p. 16, tradução minha) Assim como Vanoye, o teórico e historiador norte-americano David Bordwell chama a atenção para a técnica sonora como elemento que interferiu nos padrões atuais de escrita do roteiro cinematográfico, enfatizando, no entanto, que "estas eram utilizadas principalmente de maneira que repetiam ou ampliavam as qualidades básicas e procedimentos da narrativa clássica” (BORDWELL, 1985, p. 186).

Os autores de manuais enfatizam a necessidade de objetividade na forma do roteiro audiovisual como um todo. Observa-se, no entanto, que, ao tratarem da forma como um roteiro deve ser escrito, as descrições de imagens, ações, personagens e diálogos são o foco dos conselhos e sugestões de como escrever. Machalski, por exemplo, enfatiza a necessidade de descrever imagens.

Resulta chamativo o esmero que se põe muitas vezes na forma estilística das descrições e das ações - ou seja, uma massa de palavras que não se veem na tela e passam ao esquecimento uma vez realizado o filme - em detrimento das imagens ou ideias visuais que estão veiculando, que são realmente material cinematográfico. (MACHALSKI, 2006, p. 19, tradução minha) 
Ao descrever os elementos que constituem formalmente o relato escrito, além de enfatizarem o imagético, o visual, os autores de manuais destacam os fatores estruturais do roteiro.

O roteiro, enquanto "sistema", é feito de finais, inícios, pontos de virada, planos e efeitos, cenas e sequências. Juntos, unificados pelo impulso dramático de ação e personagem, os elementos da história são "arranjados" de uma forma particular e depois revelados visualmente para criar a totalidade conhecida como "o roteiro". Uma história contada em imagens. (FIELD, 2001, p. 86)

Ao definir a unidade estrutural básica do relato audiovisual (a cena), Field ainda prescinde do áudio em detrimento do visual, ao afirmar que "a cena é onde tudo acontece — onde você conta sua história com imagens em movimento" (FIELD, 2001, p. 118). Em suas considerações sobre a forma do roteiro acabado, Cannito e Saraiva ressaltam que "não há indicações sobre 'clímax', 'respiração' etc., nem indicações sobre as intenções de uma sequência. Tudo o que há são diálogos e rubricas indicativas de ações." (CANNITO; SARAIVA, 2004, p. 166) Sabemos que esses autores não desconsideram a presença dos som. Parece importante enfatizar, nesta busca por uma escrita que gere filmes com uma sonoridade mais complexa e significativa, o quão pouco fazem referência a ele.

O teórico e compositor francês Michel Chion leva em conta a informação sonora ao escrever sobre como deve ser a forma de um roteiro literário para uma obra audiovisual. Chion expressa a possibilidade de um roteiro ser escrito em duas colunas, uma dedicada às informações visuais e outra às informações sonoras.

Às vezes, na continuidade dialogada, a apresentação do roteiro se faz na forma de duas colunas, uma à esquerda para todo o "visual" (ações, objetos e seres visíveis), e outra à direita para todo o "sonoro" (diálogos e efeitos sonoros particulares naturalmente, não se indicarão ruídos que se derivem da própria ação, com exceção daqueles que tenham papel dramático digno de ser sublinhado: uma cor ou um timbre específicos, etc.). Mas esta disposição em duas colunas é uma convenção de que podemos prescindir. (CHION, 1986, p. 182)

Apesar de afirmar que o roteirista pode prescindir do formato em duas colunas, ao considerar a forma do roteiro como elemento que influencia na disposição das informações sonoras e visuais no papel, Chion possibilita que nos perguntemos se a forma interfere no conteúdo no momento de descrever o sonoro no roteiro audiovisual. Voltaremos a esta questão no 
Capítulo 3, no qual comparamos o roteiro escrito a fragmentos de filmes já terminados, observando o estilo de escrita de cada um deles.

Os manuais de roteiro, de forma geral, dão pouco ou nenhum espaço ao som como elemento integrante da narrativa do relato. Podemos afirmar que estabelecem uma ideia muito mais visual do que auditiva da narrativa audiovisual. O espaço dedicado ao sonoro, nos manuais, restringe-se, basicamente, ao diálogo e à música. Ao longo deste capítulo analisaremos manuais com o objetivo de encontrar as ocasiões em que fazem referência, direta ou indireta, ao som. Para isso, começaremos por investigar a presença dos aspectos imagéticos e sonoros nas narrativas dos manuais. Em seguida, daremos atenção a elementos específicos relacionados ao som identificados nos manuais: o diálogo (e não o som) como par complementar da imagem; o som como elemento formal do modelo de escrita de roteiros audiovisuais e a ideia de som como fator técnico a ser tratado em pós-produção; o som fora de campo ou em off.; o som e a música como metáforas para descrever a estrutura e o ritmo do relato.

\subsection{A imagem como ponto de partida}

Syd Field afirma repetidas vezes que o roteiro "é uma história contada com imagens" (FIELD, 2001, p. 31). Tal definição de roteiro é compartilhada, com algumas variações, por diversos autores. A imagem é o ponto de partida e o ponto de chegada; a partir dela se definem e se desenvolvem os demais elementos narrativos. Esta abordagem não é equivocada, pois grande parte do ofício do roteirista é realmente descrever imagens com palavras. Além disso, os manuais têm a função didática de evitar que roteiristas sigam a tendência de resolver tudo por meio do diálogo. Compreendemos, também, que a terminologia usada para descrever técnicas e recursos cinematográficos estão, historicamente, mais associadas ao campo visual, mesmo que não se limitem a este. Apenas gostaríamos de chamar a atenção para o fato de que o som é um recurso narrativo e expressivo, e, uma vez que está presente nas obras audiovisuais, pode ser potencializado.

A autora de manuais e consultora norte-americana Linda Seger enfatiza a importância do fator imagético desde a cena inicial do relato, afirmando que "na maioria dos bons filmes, a abordagem começa com uma imagem. Vemos algo que nos proporciona uma ideia adequada do 
lugar, ambiente ou época em que se desenvolve a história, e em algumas ocasiões até do tema." (SEGER,1991, p. 33, tradução minha) Blake Snider, considerado um dos mais populares mentores na área de roteiro audiovisual, coincide com Seiger ao tomar a imagem como ponto de partida do roteiro. Segundo ele "a primeiríssima impressão do que um filme é - seu tom, seu humor, o tipo e o escopo do filme - pode ser toda encontrada na imagem de abertura" (SNIDER, 2005, p. 72, tradução minha). Robert McKee, por sua vez, destaca a importância imagética em outro momento da estrutura narrativa, o clímax, que “deve ser 'escrito para os olhos', e não para os ouvidos" (McKEE, 2002, p. 295). Isso não significa que tais imagens não estejam acompanhadas de um som - diegético ou não - que as reforce, complemente ou resignifique. Mas chamamos a atenção para o fato de os elementos referentes ao universo sonoro estarem subentendidos ou camuflados nas recomendações dos manuais.

A ênfase à imagem pode ser atribuída ao caráter visual do relato cinematográfico, a natureza do filme como imagem em movimento, que remonta às origens do cinema e a sua fase silenciosa. $\mathrm{O}$ escritor e roteirista norte-americano Eugène Vale ajuda a entender essa primazia do imagético sobre o sonoro ao explicar a relação entre obra audiovisual e espectador. Segundo Vale, "deve-se compreender que o realismo fotográfico da câmera afeta o relato e portanto a escolha de seus materiais. A lente reduz o reino da fantasia e da imaginação do espectador de maneira considerável: a câmera visualiza os fatos por ele." (VALE, 1982, p. 8) Ou seja, a atenção do roteirista deve estar em mediar aquilo que o espectador verá na obra audiovisual. O que o espectador ouvirá fica, via de regra, em segundo plano.

O roteirista e dramaturgo brasileiro Doc Comparato justifica por meio de uma comparação com a poesia o caráter fotográfico do relato audiovisual. Comparato faz referência às considerações do poeta Stephen Spender sobre as qualidades básicas na construção de um poema:

Em seu livro Fazendo um Poema (The Making of a Poem) Spender divide o trabalho criativo em cinco qualidades básicas. Primeiro, ele destaca o fato de que o pensar poético se dá em imagens. Isto é importante para quem faz um roteiro: se prestamos atenção, veremos que não pensamos em palavras, mas em imagens. É como se tivéssemos uma câmera colocada atrás do olho (quer dizer, na imaginação). Lembrando que uma câmera tem mais acuidade visual que o olho humano e, portanto, está mais próxima da imaginação. (COMPARATO, 1983, p. 20) 
O fato de enfatizar a relação entre espectador e imagem leva os autores de manuais a pensar o roteiro a partir da informação visual e concentrar-se nela, poucas vezes dando espaço ao que diz respeito à informação sonora. Algumas de suas definiçõos do conceito de ponto de vista ajudam a entender como tais autores atrelam o processo criativo e de imaginação mais a imagens que a sons. Field ressalta que "o filme é um meio visual. Você deve encontrar maneiras de revelar os conflitos do seu personagem visualmente.” (FIELD, 2001, p. 28) Ao definir personagem, Field afirma que "personagem é um ponto de vista", ou seja, “é a maneira de olharmos o mundo. E um contexto.” (FIELD, 2001, p. 36) McKee também recorre ao olhar, à visualização, no momento de estabelecer a partir de que ponto se escreve um relato. Segundo o autor, "cada estória é ambientada em um tempo e lugar específicos, ainda assim cena a cena, enquanto imaginamos os eventos, onde nós nos localizamos no espaço para visualizar a ação? Esse é o ponto de vista." (McKEE, 2002, p. 340, grifo no original)

Ao substituir a noção de "ponto de vista" por "ponto de foco" em seu manual, o roteirista brasileiro Flavio de Campos dá espaço a outros elementos além da imagem na construção do relato audiovisual. De acordo com Campos,

ponto de foco é tudo o que atrai o foco do narrador ou de um personagem. Pode ser um objeto, um personagem, uma ação, o fio de estória que uma ação traça, um som, uma fala, um gesto, um lugar, um fenômeno da natureza, uma emoção, sentimento, percepção ou conceito; pode ser até o que está em torno da estória - como a forma de narrar ou o espectador -, e tudo o mais que eu não tenha lembrado. (CAMPOS, 2007, p. 33)

Mesmo valendo-se de uma metáfora visual, fotográfica (a ideia de foco), Campos amplia as possibilidades do que pode ser visto, sentido ou ouvido pelo narrador que conduz o relato. $\mathrm{O}$ autor, no entanto, limita-se a citar o som como possibilidade narrativa, sem desenvolver neste momento como o sonoro pode narrar ou ajudar a contar uma história ou expressar uma informação ou sensação audiovisual. No Capítulo 2 exploraremos a ideia de ponto de audição (que combina som e imagem), desenvolvida por autores como Chion e Rick Altman.

Os roteiristas Newton Cannito e Leandro Saraiva, ao sugerirem que se deixe "de lado a ideia de que roteiro é basicamente diálogo", reforçam a ideia do roteiro audiovisual como instrumento em que se deve valorizar a imagem. Eles propõem uma 
visão mais especificamente cinematográfica do roteiro, que o encare como estímulo à visualização da narrativa, envolvendo o diálogo - e as vozes off - no conjunto do fluxo audiovisual com elipses, montagens paralelas, manipulações temporais, música, etc. (CANNITO; SARAIVA, 2004, p. 18, grifo meu).

Ao definirem o roteiro como instrumento de comunicação, os autores complementam que ele “deve ser escrito de modo a facilitar ao seu leitor a visualização da história". (CANNITO; SARAIVA, 2004, p. 18, grifos meus). Os mesmos autores descrevem, em seu manual, a necessidade da existência, na escrita de roteiros, de uma "dramaturgia plástica", na qual se apresentam e desenvolvem os elementos visuais da cena (CANNITO; SARAIVA, 2004, p. 204). Tal definição nos faz pensar se não seria o caso de buscar também uma dramaturgia sonora, na qual estariam desenvolvidos os elementos sonoros na cena. Essa noção, inclusive, ajudaria na missão didática dos manuais de roteiro audiovisual de afastarem essa escrita das escritas para teatro ou televisão, via de regra focadas no diálogo.

Não podemos deixar de mencionar caminhos que apontam para exceções dentro dos manuais: em alguns momentos se leva o som em consideração, mesmo que superficialmente. $\mathrm{O}$ roteirista de Hollywood Terry Rossio, ao enumerar uma série de regras de escrita, resume a ordem de importância de elementos na narrativa: "Visual, Auditivo, Verbal - nessa ordem. A expressão de alguém que acaba de levar um tiro é melhor; o som da bala o atingindo é o segundo melhor; a pessoa dizendo: 'Eu levei um tiro' é apenas o terceiro melhor." (ROSSIO, 1997, p. 8, tradução minha) No exemplo dado, parece fazer sentido a ordem proposta pelo autor. Mas apenas em uma primeira leitura: seria necessário entender em que contexto a sequência estaria inserida. Esse tipo de regra ou generalização pode distanciar o roteirista das especificidades e intenções sobre o que escreve. Ou seja, se ele parte da regra dificilmente conseguirá avaliar qual a melhor forma de narrar determinado conteúdo (visual, auditiva ou verbal).

Os manuais variam no que diz respeito à ordem de auditivo e verbal - muitas vezes ignorando a possibilidade do auditivo - mas a ideia de filmes feitos para os olhos perpassa, ainda que de forma sutil, todos os manuais de roteiro. Rossio cita a definição de Lawrence Kasdan (outro roteirista de Hollywood), segundo ele o resumo mais eloquente, prático e simples do que é escrever um roteiro: "Você escreve o que vê." (ROSSIO, 1997, p. 57, tradução minha) É interessante observar como Rossio prescinde do sonoro e reforça a ideia de filme feito para os olhos ao explicar a definição de Kasdan: "ele quer dizer escreva o que você vê como se o filme 
terminado estivesse passando na sua frente. Momento a momento transcreva esses acontecimentos, e você não errará muito, estilisticamente, em fazer o filme 'acontecer' no olho da mente do leitor." (ROSSIO, 1997, p. 57, tradução minha)

A prioridade que dá ao visual fica clara em outras passagens do manual de Rossio, em que ele afirma diretamente que o som é um acessório dispensável para a compreensão da mensagem que a obra audiovisual pretende passar. "Em sua melhor forma, a resolução da tarefa, como uma ação física, torna-se uma imagem fílmica poderosa para o filme. Você poderia literalmente desligar o som e ver graficamente a história acontecer até a sua conclusão." (ROSSIO, 1997, p. 91, tradução minha) Tal concepção não é equivocada (realmente a compreensão do relato não é afetada), mas demonstra uma ideia limitada sobre como os recursos sonoros podem contribuir com a significação da narrativa.

Snider segue a mesma linha ao tratar dos filmes do gênero que ele intitula "monstros na casa".

Este gênero tem uma origem distante e foi provavelmente o primeiro conto que o homem contou. Tem duas partes funcionais: Um monstro. Uma casa. E quando você coloca pessoas nessa casa, desesperadas para matar o monstro, você tem um tipo de filme tão primário que se traduz a todos, em qualquer lugar. É o tipo de filme sobre o qual gosto de dizer, "Você pode explicá-lo a um homem das cavernas". Não se trata de ser burro, mas de ser primário. E todos entendem o simples mandamento primário: Não... seja... comido! Por isso este gênero é responsável por tantos sucessos e franquias mundiais. Você provavelmente pode passar a maioria desses filmes sem a trilha sonora e ainda assim entendê-los. (SNIDER, 2005, p. 26, tradução minha)

As afirmações de Rossio e Snider sobre a possibilidade de entender uma cena ou um filme completo sem o uso do som reforçam a ideia de que fazer um filme é contar uma história ou expressar-se por meio de imagens.

Apesar de enfatizar a imagem, McKee dá um pouco mais de espaço ao som ao definir os componentes da obra audiovisual, como quando, por exemplo, define a ideia de "sistema de imagens". Segundo o autor, tal sistema

é uma estratégia de motivos ornamentais, uma categoria de imagem embebida no filme que se repete, em imagem e som, do começo ao fim com grande variação, 
mas com igual sutileza, como uma combinação subliminar que aumenta a profundidade e a complexidade da emoção estética. (McKEE, 2002, p. 374)

Jean-Claude Carrière e Pascal Bonitzer, por sua vez, afirmam que "é a imagem que conta a história” (CARRIERE; BONITZER, 1998, p. 108, tradução minha).

Não se trata, pois, somente de saber contar, mas de saber contar em função da imagem, "sob o ditado da imagem", para parafrasear uma fórmula de Kossowski. Um roteirista cinematográfico não deve gostar só de narrar, gostar de histórias, deve gostar também da imagem, amar as imagens. (CARRIERE; BONITZER, 1998, p. 106, tradução minha)

Os autores, no entanto, aconselham o roteirista a

imaginar imagens compactas, belas e ricas, imagens emblemáticas, que cada uma pareça conter o filme inteiro. Buscar para cada cena a imagem central e construir a cena ao redor dela. Deixar o diálogo intervir apenas em segundo lugar, ao menos que o centro da cena seja uma palavra ou um efeito sonoro. (CARRIERE; BONITZER, 1998, p. 46-47, tradução minha)

Apesar de também terem a imagem como ponto de partida, tais autores são uma exceção nos manuais de roteiro ao aconselhar "não esquecer nunca o som, não considerá-lo nunca como acessório. Se constrói a trilha sonora de um filme desde o roteiro. É bom, quando o roteiro é dado como terminado, fazer uma leitura minuciosa concentrando-se só no som, tentando ouvir o filme.”(CARRIERE; BONITZER, 1998, p. 108, tradução minha)

Carrière e Bonitzer afirmam que é possível - e necessário - construir e escrever a narrativa audiovisual pensando conjuntamente no som e na imagem. E, diferente de outros manuais, fazem referência não apenas à música e ao diálogo, mas à trilha sonora como um todo, ou seja, recursos sonoros que incluem vozes, ruídos e músicas (diegéticos ou extradiegéticos) que afetam, segundo Bordwell e Thompson (BELTON; WEIS, 1985, p. 181-199), volume, ritmo, tempo (de projeção e do relato) e espaço fílmicos.

É a partir da noção de que a trilha sonora se escreve desde o roteiro que buscaremos analisar as sequências de roteiros e filmes no Capítulo 3 desta dissertação. 


\subsection{O diálogo como som da imagem}

Há uma recorrência significativa de oposição entre "cenas de imagem" e "cenas de diálogo" nos manuais de roteiro. Assim, o par da imagem nos manuais, por vezes, não é o som, mas o diálogo, e ambos formam os pilares fundamentais da construção de um roteiro:

Geralmente, há dois tipos de cenas: um, em que algo acontece visualmente, como uma cena de ação - a perseguição que abre Star Wars (Guerra nas Estrelas), ou as cenas de luta em Rocky (Rocky, um Lutador). O outro é a cena de diálogo entre uma (monólogo) ou mais pessoas. A maioria das cenas combina os dois tipos. Numa cena de diálogo, geralmente há alguma ação acontecendo, e numa cena de ação há geralmente algum diálogo transcorrendo. (FIELD, 2001, p. 118)

Segundo McKee, "na maioria dos casos, quanto melhor for a qualidade da estória (storytelling), mais vivas são as imagens, mais afiado é o diálogo" (McKEE, 2002, p. 31). O autor faz esta afirmação após dizer que "a arte da estória está em decadência [...] A música e os efeitos sonoros vêm se tornando cada vez mais tumultuosos.” (McKEE, 2002, p. 26)

Vanoye refere-se ao que chama de "princípio da alternância" para caracterizar os tipos de função de uma cena, e um dos pares alternos é justamente a dupla visual x dialogado:

O principio da alternância conduz a caracterizar a cena de maneira contrastada (visual/dialogada, íntima/coletiva, de ação/de descanso, de tensão/de distensão, para não falar de toda a gama das emoções que servem para precisar os contrastes: atemorizar, fazer chorar, fazer rir ou sorrir). (VANOYE, 1996, p. 118, tradução minha)

Seger também trata o diálogo como oposto à imagem para explicar que costuma ser mais fácil para o espectador começar a absorver as informações do filme a partir dos olhos e não dos ouvidos.

Os filmes que começam com diálogo, no lugar de fazê-lo com uma imagem visual, resultam mais difíceis de seguir. Isso porque o olho capta os detalhes com muito mais rapidez que o ouvido. Se proporcionamos pela palavra informação chave, antes que o público tenha entrado na historia, ou tenha uma ideia do estilo, ou do modo de falar de um personagem. será difícil que se lembre dessa informação e provavelmente não a incorporará. Ao escrever procure, portanto, começar com uma imagem, uma sensação, uma informação sobre onde estamos, do ritmo , do estilo do filme. Diga tudo o que puder com essa imagem. Coloque-nos no ambiente da história e, se for possível, crie uma metáfora que nos diga algo sobre o tema através das imagens. (SEGER, 1991, p. 33-34, tradução minha) 
Observe-se, porém, que em nenhum momento Seger faz referências a outros sons que não o diálogo. Um pouco mais adiante em seu texto, ao analisar um fragmento do filme Witness (Testemunha - 1985) fica claro que quando se refere à informação sonora não está contemplando o som como um todo, apenas o som emitido pelos atores em forma de falas: "Observamos também que não há diálogo. A imagem diz tudo, detalhe a detalhe, até que adquirimos consciência do lugar, ritmo, ambiente e textura do relato.” (SEGER, 1991, p. 35, tradução minha) Esta "imagem que diz tudo", no entanto, em toda a sequência inicial do filme, está acompanhada por música, que ajuda a introduzir o ritmo e o tom emocional do filme conforme são apresentados espaço (campo, milharal) e personagens (comunidade amish). Apesar de a música ser o som mais evidente, há toda uma articulação de ruídos e efeitos sonoros, por exemplo o dos cavalos e carruagens que se movimentam pela estrada. A função dessa composição sonora é apresentar o espectador ao universo sonoro e ao ponto de vista do filme.

A autora incentiva ainda a expressão do conflito por meio de imagens e ação junto com o diálogo: "Como se expressa o conflito? Utilizo as imagens e a ação, ao mesmo tempo em que o diálogo, para mostrá-lo?” (SEGER, 1991, p. 198, tradução minha) Seria interessante se essa ideia de composição extrapolasse a dupla diálogo-imagem e considerassem a dupla imagem-trilha sonora, criando um conjunto audiovisual complexo.

Saraiva e Cannito também enfatizam a ideia de que as cenas são compostas por imagens e/ou diálogo, lembrando que "a capacidade do cinema de narrar por imagens, muitas vezes supera a necessidade do diálogo - e isso deve ser indicado já no roteiro" (CANNITO; SARAIVA, 2004, p. 64).

Comparato tende ao mesmo tipo de hierarquização entre visual e verbal, considerando também imagem e diálogo como a dupla principal da composição de um roteiro para obra audiovisual: “o visual, no cinema e na televisão, é mais importante que o verbal. Se o autor puder enviar uma informação visual no lugar de uma verbal, é melhor. Desta forma, uma expressão ou reação silenciosa de um personagem pode ser mais significativa que uma interferência verbal." (COMPARATO, 1983, p. 96) O autor chama a atenção para o peso da imagem e o peso da palavra no cinema, concluindo que "a palavra perde consideravelmente sua importância, substituída pelo maior peso da imagem" (COMPARATO, 1983, p. 14). 
Essa diferença de peso ou importância da imagem e da palavra na construção do drama audiovisual também é destacada por Seger:

As cenas que unicamente revelam ao personagem sem ação não conseguem sequer dar-lhe o impulso motivacional necessário. E como o drama está mais orientado à imagem que à palavra, qualquer coisa que se diga em vez de mostrar diminui a força dramática da cena. (SEGER, 1991, p. 169, tradução minha)

Chion, por sua vez, observa ainda que, em um tipo de cinema mais "visual", o diálogo costuma ter uma função importante. Até mesmo antes do advento do filme sonoro, o diálogo já ocupava um papel de destaque na narrativa, composta pela dupla imagem e diálogo. O autor afirma que "estes diálogos não se ouviam, mas seu sentido nos era comunicado mediante a mímica dos atores e 'intertítulos' (letreiros). Os personagens do cinema mudo não eram nada mudos.” (CHION, 1986, p. 73, tradução minha)

Assim, os manuais de roteiro apontam para a predominância da voz como elemento sonoro de destaque na construção de obras audiovisuais. Bordwell chama a atenção para esse aspecto ao analisar o papel do diálogo nos filmes, afirmando que "na maioria dos filmes, a fala parece ocupar o primeiro plano, e o ruído, o fundo.” (BORDWELL, 1985, p. 119) Esta colocação pode ser completada pela definição de Altunaga sobre o que considera uma "ditadura semântica":

"O diálogo sobre a imagem é uma ditadura semântica. Você não tem a oportunidade de compreender por você mesmo, mas pelo que o personagem está te dizendo. Então o personagem não é mais que a extrapolação do conteúdo, do sentido que o diretor e o autor querem dar ao acontecimento do que está ocorrendo." (ROJAS, 2016, p. 93, tradução minha)

\section{$1.3 \mathrm{O}$ resto do som: presença de componentes da trilha sonora nos manuais}

Seguindo com as regras técnicas sobre a forma como se deve escrever um roteiro, Field aconselha o roteirista a assinalar, com moderação, os pontos do relato em que pode haver efeitos sonoros:

Efeitos sonoros e de música são sempre grafados em maiúsculas. Não exagere nos efeitos. O último passo no processo de produção de filmes é colocar a música e os efeitos sonoros. O filme está "fechado", isto é, a pista de imagens não pode ser mudada ou alterada. Os editores correm todo o roteiro procurando deixas de músicas e de efeitos sonoros, e você pode ajudá-los colocando as referências a música e efeitos sonoros em maiúsculas. (FIELD, 2001, p. 161) 
Rossio segue a mesma linha de Field ao sugerir que se destaquem efeitos sonoros ao longo das frases escritas no roteiro: "Efeitos sonoros e efeitos especiais podem ser escritos em maiúsculas, que têm o efeito adicional de fazer o roteiro parecer mais ativo. 'Ele gira, DISPARA e mergulha para fora enquanto o caminhão desgovernado EXPLODE' pelo menos passa a ideia, para um executivo ocupado, de que há ação.” (ROSSIO, 1997, p. 70, tradução minha) Acreditamos que esta forma de destacar os efeitos sonoros pode levar a duas falhas de interpretação. A primeira seria a de ignorar o som das partes do texto em que ele não é destacado, pois esta forma de escrita pode fazer parecer que só o que está em destaque soa no filme. A segunda (devido a convenção da linguagem escrita contemporânea de o que está em caixa alta é um som alto, ou gritado) seria a de pressupor que todo o som destacado é necessariamente alto.

Field afirma que "o cinema lida com dois sistemas — o filme, que nós vemos, e o som, que ouvimos. A parte de filme é completada antes de ir para a finalização de som, e depois as duas partes são colocadas juntas em sincronismo. É um processo longo e complicado.” (FIELD, 2001, p. 61) Em seu manual, Comparato recomenda a indicação de marcações ou temas musicais no roteiro, assim como a descrição de efeitos ou ruídos. Acrescenta, contudo, que "uma vez dada a indicação o técnico de som saberá o que fazer” (COMPARATO, 1983, p. 77). Essa delegação do som ao processo de pós-produção diminui as possibilidades de ele ser levado em conta como agente narrativo e expressivo no momento de criação do relato.

McKee também sugere que as indicações a músicas e a efeitos sejam limitadas ao longo do texto escrito no formato de roteiro. O autor, no entanto, dedica parte de seu manual a criticar o que considera um uso "espetacularizado" do som nos filmes, tanto aqueles considerados "de arte" como os hollywoodianos, em que "a narrativa é forçada a virar uma superfície ofuscante de espetáculo e som para distrair o público do vazio e da falsidade da estória” (McKEE, 2002, p. 70). McKee associa o desenvolvimento técnico a uma aproximação de um hiper-realismo que por sua vez levaria à espetacularização em detrimento da história.

A cada década, inovações técnicas desovam uma multidão de filmes mal contados, com o único propósito de explorar o espetáculo. A invenção do filme em si, uma espantosa simulação da realidade, causou grande excitação no público, seguida por anos de histórias insípidas. Com o tempo, porém, o filme mudo evoluiu para uma magnífica forma de arte, para ser destruído pelo advento do som, uma simulação ainda mais realista da realidade. Filmes do começo dos anos 30 deram um passo para trás, quando o público sofria propositalmente com estórias fracas pelo prazer 
de ouvir os atores conversando. O filme falado então cresceu em poder e beleza, para ser nocauteado apenas pela invenção da cor, do filme 3-D, da widescreen, e agora da computação gráfica, ou CGI. (McKEE, 2002, p. 36)

Observa-se, assim, que o espaço concedido ao som no texto do roteiro literário, ou seja, sua participação na forma como o roteiro é escrito, é levado em conta em alguns dos manuais analisados. Em parte dos materiais, o som aparece como uma faceta técnica a ser tratada em uma etapa posterior, na pós-produção, portanto não deve ser escrita e não tem relação com o trabalho do roteirista.

Outro dos aspectos de destaque da voz como elemento sonoro principal nos manuais é a atenção dada à voz off ou over $^{1}$ como principal elemento sonoro fora de plano. Vanoye destaca a composição de imagens com vozes em off, mais uma vez considerando o diálogo como par complementar da imagem:

Os roteiros com narrador (es) e voz em off desenvolveram um modelo contrapontístico de narração especificamente cinematográfico, uma vez que têm como base a utilização conjunta da imagem e do som, modelo rico em implicações reflexivas [...], emocionais ou musicais [...], vozes em off flutuantes e imateriais, por não estar "associadas aos corpos" [...]. (VANOYE, 1996, p. 81, tradução minha)

McKee também recomenda o uso da voz off como complemento, afirmando que "se a narração pode ser removida e a estória continua em pé, então você provavelmente usou a narração para seu único bom propósito - como contraponto” (McKEE, 2001, p. 323).

Machalski, por sua vez, vê no recurso da voz fora de campo uma forma de amenizar diálogos explícitos ou informativos, tornando-os mais sutis.

Mostrar a um interlocutor (em vez do falante) e suas reações faciais ou uma cena sugestiva enquanto se ouve a voz em off do falante pode criar a distância e o espaço necessários para que o explícito não o pareça tanto e para criar uma abertura à imaginação. Se são mostrados no campo visual os que falam, o perigo do explícito se torna mais patente, e às vezes se necessita trabalhar cuidadosamente no diálogo em subtextos e conteúdos implícitos. A maneira de sugerir modifica o tom da narração e exige determinados recursos roteirísticos. A tela pode funcionar para enquadrar ou para encobrir o que se narra verbalmente. (MACHALSKI, 2006, p. 36 , tradução minha)

\footnotetext{
${ }^{1}$ Por voz off entendemos a voz que está fora de quadro, mas é diegética. A voz over, por outro lado, é a voz que vem de outro tempo e/ou espaço, portanto não diegética.
} 
Bordwell amplia a atenção para outros sons além do diálogo provenientes de fora de campo, diegéticos ou não diegéticos, ao tecer observações sobre o espaço em off da narração:

O som tem um potencial especificamente intenso para dar indicações a respeito do espaço em off. Os filmes atuais incluem com frequência sons ambientes para sugerir um mundo em off vago mas coerente. A localização do som pode jogar sutilmente entre o mundo da história e um lugar indefinido que podemos chamar som over, do qual provém a música não diegética e os comentários. (BORDWELL, 1985, p. 120, tradução minha)

Comparato também leva em consideração o universo criado fora de campo, e chama a voz do narrador em off de "presença sonora", citando como exemplo os filmes de Woody Allen ou os desenhos animados de Walt Disney (COMPARATO, 1983, p. 66). A denominação utilizada pelo autor nos faz pensar que muitas vezes os manuais só consideram "presença sonora" aquela que está fora de campo, em off, deixando um pouco de lado as presenças sonoras dentro de campo, ou mesmo itinerantes.

Apesar de não serem o foco dos manuais de roteiro, o som e a trilha sonora para além do diálogo e da voz recebem diferentes tipos de considerações ao longo dos guias analisados.

Segundo Bordwell, "todos os materiais cinematográficos funcionam de forma narrativa, não só a câmera, mas também a fala, os gestos, a linguagem escrita, a música, a cor, os processos óticos, a iluminação, o figurino, inclusive o espaço e o som em off” (BORDWELL, 1985, p. 20, tradução minha). Comparato chama a atenção para todos os elementos que compõem a cena, e afirma que "toda cena tem seu momento principal, sua razão de existir. Esse momento pode estar colocado no diálogo, na imagem, no som, no figurino, no tempo da cena, etc., enfim, em qualquer momento da cena." (COMPARATO, 1983, p. 101) O autor, porém, concentra seus conselhos e sugestões nas partes imagéticas e dialogadas da cena.

Campos dedica um pouco mais de espaço em seu manual para tratar do som, definido pelo autor como "toda emissão sonora":

São elementos de estória os sons que você ou o seu narrador podem colher da massa de uma estória; são recursos de narrativa os sons que você ou o seu narrador podem agregar à massa de uma estória. Assim, são elementos de estória, por exemplo, o som do carro que chega, da urina que bate no solo, dos tiros, das buzinadas, dos berros, dos estalidos com a boca ou da música que um personagem toca. São recursos de narrativa, por exemplo, os efeitos sonoros, as músicas 
incidentais, as risadas gravadas e a voz over. (Fala é som que, de tão importante, merece seção exclusiva, em seguida desta.) Um som pode ser lírico, épico ou dramático. (CAMPOS, 2007, p. 147)

Segundo Campos, os sons épicos passam informações sobre os personagens e suas ações. Já os líricos são expressões de sentimentos dos personagens, enquanto os dramáticos têm como objetivo motivar a ação de outros personagens. Tais sons, segundo o autor, pertencem ao mundo do roteiro se cumprem uma função no relato:

Um som pertence ao roteiro se passa informação importante sobre um elemento da estória, expressa uma subjetividade ou motiva a reação de um personagem. Se não possui nenhuma dessas funções, o som não pertence ao roteiro e deve ser ignorado. Se descreve um percurso dentro da narrativa, o som traça uma trilha. (CAMPOS, 2007, p. 149)

Seger menciona o som quando explica o recurso da repetição aplicado à escrita de roteiros em seu manual: “A repetição pode ser realizada por meio de imagens, do diálogo, do tratamento dos personagens, do som ou do uso combinado de todos esses elementos para manter a atenção do espectador concentrada em uma ideia.” (SEGER, 1991, p. 115, tradução minha) A autora continua mencionando o som quando trata de motivos recorrentes que possam ser aproveitados ao longo da trama:

Busque motivos que possam ser aproveitados. Para isso, pode ser útil revisar objetos físicos aos quais fazer referência no roteiro. Você pode aproveitar algum deles para criar um motivo recorrente de imagem? Porque pode ser que haja algum som que seja parte integrante da tua história e esteja pedindo a gritos o papel de motivo recorrente. Em uma história de mistério pode ser o barulho da borracha de uns sapatos, que pode servir tanto de motivo como de antecedente e cumprimento. Em uma história do espaço pode ser um ritmo ou uma melodia especial, como o som utilizado em Contatos imediatos de terceiro grau para comunicar-se com os extraterrestres. (SEGER,1991, p. 119, tradução minha)

Seger segue seu discurso tratando das possibilidades de repetições e antecipações na construção das tramas dramáticas da história. Após mencionar brevemente a possibilidade de os recursos sonoros entrarem nessa construção, a autora se dedica a dar exemplos mais relacionados à imagem, sugerindo ao final que o roteirista se pergunte: "como posso construir dramaticamente ideias através das imagens?” (SEGER, 1991, p. 120, tradução minha) 
Em alguns casos, apenas a música (e não todos os elementos sonoros como explicamos anteriormente) é considerada como trilha sonora. Saraiva e Cannito, por exemplo, falam da música como recurso de comentário planejado: "uma trilha sonora pode servir para isso - como a trilha de antigas bandas de rock de um só sucesso, como em Houve uma vez dois verões" (CANNITO; SARAIVA, 2004, p. 7.). Os mesmos autores, mesmo sem chamar a atenção para o som, demonstram que os elementos sonoros podem fazer parte de formas de expressões audiovisuais mais líricas, como “o uso de fluxos de imagens que revelam o que se passa no íntimo do personagem. Esses momentos líricos são compostos por pura expressão visual, como no início de Apocalipse Now (Francis Ford Coppola, 1979).” (CANNITO; SARAIVA, 2004, p. 73) Apesar de os autores usarem o termo "pura expressão visual” e só mencionarem os aspectos visuais da sequência, ignorando a trilha sonora que não é música, trata-se de um fragmento fílmico em que imagem e som estão bastante unidos e articulados, gerando uma expressão lírica audiovisual. Esta sequência já foi analisada por diversos autores ${ }^{2}$.

Chion, por sua vez, cita um exemplo do engenheiro de som Lewis Herman para falar sobre sons que "coroam" ou enfatizam determinadas ações:

De to cap (coroar), o capper é, diz Lewis Herman, um efeito de relevo, de acentuação de uma frase, uma expressão ou uma ação criadas por um ruído, uma nota musical, um gesto, um efeito simultâneo. O exemplo dado por Herman é o do som de um relógio cuco que pontua uma observação ácida; lembra que se deve preparar o capper para que ele produza esse efeito. Neste sentido, o exemplo canônico de capper é o som do trovão que, nos melodramas ou nos filmes de terror, sublinha as terríveis revelações e os juramentos fatais, em cenas sensatamente situadas durante uma tempestade. (CHION, 1990, p. 160, tradução minha)

O exemplo acima mostra o som como complemento que enfatiza ou potencializa o significado ou a intenção de determinada imagem.

Voltamos a Bordwell para retomar o papel do som na construção do relato cinematográfico desde o roteiro. $\mathrm{O}$ autor considera as obras audiovisuais em termos de espaços cenográficos, ou seja, “o espaço imaginário da ficção, o 'mundo' em que a narração sugere que sucedem os acontecimentos do argumento. Baseando-nos em indícios visuais e audíveis, atuamos para construir um espaço de figuras, objetos e campos, um espaço de maior ou menor profundidade,

\footnotetext{
${ }^{2}$ Mencionaremos uma dessas análises no Capítulo 2
} 
alcance, coerência e solidez." (BORDWELL, 1985, p. 113, tradução minha) Esse espaço cenográfico a que Bordwell se refere determina que um filme se constitua a partir de três tipos de indícios: "espaço dos planos, espaço da montagem e espaço do som. Cada um destes grupos implica também a representação do espaço na tela ou fora da tela.” (BORDWELL, 1985, p. 113, tradução minha)

Não seria o caso, então, de pensar nesses espaços desde a construção escrita do roteiro? Ou seja, a partir do universo das palavras buscar não só o mundo das imagens, mas também o do som?

\subsection{A música como metáfora para estruturar a escrita}

Alguns dos autores de manuais recorrem ao universo sonoro, mais especificamente o da música, para estabelecer metáforas entre conceitos como composição, partitura, estrutura, beat e elementos da escrita do roteiro. Tais comparações, apesar de não chegarem a abordar o som como elemento narrativo em si, podem indicar que existe uma natureza para além da visual na composição da estrutura e do conteúdo do roteiro cinematográfico, como observaremos em seguida.

Cannito e Saraiva afirmam que, na leitura do roteiro, “é preciso 'ouvir' o arranjo que vai formando a escaleta, sentindo quando uma cena está 'uma oitava' acima, ou quando a passagem de um tom a outro está abrupta demais" (CANNITO; SARAIVA, 2004, p. 126). Machalski, por sua vez, afirma que o roteiro é "um pouco como uma melodia à que temos que acrescentar a harmonia, a instrumentação, o ritmo, a atmosfera [...] A fluidez de um roteiro se determina também com base em algo como um ‘ouvido' roteirístico: o roteiro pode estar bem 'afinado’ ou 'desafinado'.” (MACHALSKI, 2006, p. 24-25, tradução minha) Essas afirmações nos encaminham a uma percepção mais subjetiva e menos técnica da escrita do roteiro, e ao mesmo tempo nos aproxima de uma questão importante para o ofício da escrita audiovisual: as palavras não são imagens nem sons, assim como as notas musicais escritas em uma partitura não são a música. O filme só será filme quando as "notas" propostas pelo roteiros forem lidas, interpretadas e executadas. 
É McKee quem dedica mais páginas de seu manual na aproximação entre a escrita do roteiro e a música, partindo do princípio de que se deixarmos de lado o conteúdo de filmes de grandes roteiristas, e estudarmos apenas a padronização pura dos acontecimentos,

veremos que, como uma melodia sem a letra, ou uma silhueta sem a matriz, seus formatos de estória são fortemente carregados de significado. A seleção e arranjo (ordem?) do contador de estória para os acontecimentos é sua metáfora mestra para a interconectividade de todos os elementos da realidade. (McKEE, 2002, p. 22)

O conceito de conceber uma história, para McKee, é como o conceito da composição da música: "Nós ouvimos canções a vida inteira. Nós sabemos dançar e cantar junto. Nós achamos que entendemos de música até tentar compor. O que sai do piano assusta o gato.” (McKEE, 2002, p. 31) Assim sendo, tal qual o estudante de música, o roteirista precisa passar por uma etapa anterior à escrita, na qual estuda as ferramentas das quais dispõe para compor o relato.

Uma estória bem contada é uma unidade sinfônica na qual estrutura, ambiente, personagem, gênero e ideia se fundem. Para descobrir sua harmonia, o roteirista deve estudar os elementos da estória como instrumentos de uma orquestra primeiro, separadamente, depois, em concerto. (McKEE, 2002, p. 41)

Após esta etapa, a escrita em si é considerada como análoga à composição, que "significa ordenar e ligar as cenas. Como um compositor escolhe notas e acordes, nós moldamos as progressões selecionando o que incluir, excluir e colocar antes e depois do que." (McKEE, 2002, p. 275)

Apesar de priorizar ações e imagens (além do diálogo) ao estabelecer seu método para a escrita de roteiros, McKee busca distanciar o relato audiovisual da mídia espacial (pintura, escultura, arquitetura ou fotografia), e aproximá-lo das formas temporais (música, dança, poesia e canção). Assim, ao mesmo tempo em que afirma que o clímax deve ser escrito para os olhos, e não para os ouvidos (como vimos anteriormente), diz que

o primeiro mandamento de toda arte temporal é: guardai o melhor para o final. $\mathrm{O}$ movimento final de um balé, a coda de uma sinfonia, a parelha de versos de um soneto, o último ato e seu Clímax da Estória - esses momentos culminantes devem ser a experiência mais gratificante e significativa de todas. (McKEE, 2002, p. 112)

McKee segue suas comparações afirmando que o conflito está para a história assim como o som está para a música, uma vez que tem a função de manter a atenção do espectador ao longo 
do que chama de arte temporal. O autor chega a explicar sua comparação demonstrando como o som é importante para a expressão musical.

Na música, o efeito é alcançado através do som. Instrumentos ou vozes nos capturam e nos carregam, fazendo o tempo desaparecer. Imagine que estamos ouvindo uma sinfonia, e a orquestra subitamente para. Qual seria o efeito? Primeiro, confusão, enquanto nós imaginamos por que eles pararam, e então muito rapidamente nós ouvimos na nossa imaginação o tique-taque do relógio. Tornamonos totalmente conscientes da passagem do tempo, e como o tempo é muito subjetivo, se a orquestra ficasse três minutos em silêncio, a impressão seria de trinta. (McKEE, 2002, p. 202)

A metáfora musical, portanto, funciona aqui como um apoio para explicar estruturalmente como funciona o roteiro, não para caracterizar o som como elemento narrativo e expressivo do cinema. McKee se vale de outros conceitos estruturais da música e sua terminologia para explicar os componentes do roteiro, como por exemplo a ideia de beat (batida), segundo ele "o nível de atividade dentro de uma cena, através de diálogo, ação ou uma combinação" (McKEE, 2002, p. 279). Seger, por sua vez, considera o beat um incidente ou acontecimento dramático, e também utiliza a metáfora da composição musical para explicá-lo.

Em música, uma sucessão de beats forma um compasso. Ao incorporar mais beats, se forma uma frase musical, logo uma melodia, e por fim a canção completa . Um drama funciona de modo similar. Momentos dramáticos individuais, um depois do outro, criam uma cena. Os de várias cenas, um depois do outro, criam um ato, e os de cada ato, um depois do outro, criam a história. (SEGER, 1991, p. 44, tradução minha)

Seger busca na música a ideia de coerência, coesão, sequenciamento e unidade que supostamente deve ter um roteiro.

Os usos musicais, logicamente, recorrem a motivos musicais ou a ritmos. Determinado instrumento pode, por exemplo, ser o que desenvolve tema principal ao longo de uma sinfonia. Ou talvez os trombones, trompetes ou tambores repitam várias vezes uma melodia ou ritmo. A música adquire seu sentido de coesão porque advertimos um principio, um meio e final, e conta com as repetições como recurso para fortalecer a unidade da peça. (SEGER, 1991 p. 102, tradução minha)

Em seu manual, Vanoye, como outros autores, usa exemplos de filmes já prontos para definir regras ou sugestões de escrita de roteiros. Em sua aproximação entre estrutura musical e estrutura do relato audiovisual ele cita a experiência do cineasta francês Eric Rohmer: "Concebi meus Contos Morais na forma de seis variações sinfônicas. Como ele (o músico), vario o motivo 
inicial, o faço mais lento ou o acelero, o alongo ou o diminuo, lhe dou corpo ou o depuro." (VANOYE, 1996, p. 115, tradução minha)

Todas essas metáforas nos levam a acreditar que, apesar de raras vezes os manuais pensarem o sonoro como elemento narrativo, há uma necessidade de evocar o sonoro ou o musical quando se quer expressar ritmo, lógica estrutural e velocidade do relato.

\subsection{Qual o som dos manuais?}

A análise dos manuais de roteiro nos permite afirmar que o som não é um elemento narrativo muito explorado por aqueles que se dedicam a dar conselhos e sugestões sobre como escrever um roteiro. Nossas observações sobre os diferentes aspectos do som como elemento narrativo nos levam a perguntar até que ponto o som pode ou deve ser escrito.

\section{Segundo Bordwell,}

a maioria das teorias fílmicas recentes se baseiam em pressupostos sobre a narração que apresentam deficiências cruciais: muitas teorias se baseiam em débeis analogias com as representações pictóricas ou verbais, enfatizam certas técnicas fílmicas, concentram ou isolam os mecanismos narrativos à custa da totalidade do filme, e imputam uma passividade fundamental ao espectador (BORDWELL 1985, p. XIV$\mathrm{XV}$, tradução minha).

Esta afirmação nos faz indagar se os manuais de roteiro seriam fruto dessa base teórica. A suposta passividade do espectador e a ênfase no pictórico e no verbal estariam relacionados à forma de escrever ou não escrever o som para os filmes?

Para nos aprofundarmos na questão e para estabelecer um diálogo que complemente ou até mesmo contradiga o que é estabelecido pelos manuais de roteiro, veremos, no Capítulo 2, como o roteiro é levado em conta pelos que pensam o som para a construção do relato audiovisual. 


\section{Capítulo 2: Guias sonoros: o roteiro no som}

Para tentar entender o papel do roteiro a partir da perspectiva sonora, e para complementar as informações sistematizadas pelos manuais de escrita de obras audiovisuais, buscamos textos que se referem ao som como elemento narrativo, expressivo e construtivo de filmes de ficção. Esta análise tem dois objetivos principais: o primeiro deles é entender até que ponto aqueles que pensam o som consideram a etapa de escrita do roteiro como parte do processo de construção sonora do relato; o segundo é buscar nos estudos do som elementos que possam ajudar a pensar uma escrita de roteiros "mais sonora", ou que contribua para a factura de filmes em que o som não seja apenas um acompanhamento da imagem. A quais ferramentas um roteirista pode recorrer para pensar o som ao longo do processo de escrita de um roteiro?

Partimos da ideia de que os filmes são um todo audiovisual e de que imagem e som são indissociáveis em termos de geração de sentido. Para efeitos de análise, no entanto, iremos separar os elementos sonoros, lembrando sempre que, como afirma o compositor e professor argentino Carmelo Saitta, "muitos aspectos da temporalização e da espacialização dependem do som, e este é um fator de unificação da cadeia audiovisual, um fator de pontuação, assim como um fator narrativo e expressivo" (SAITTA, 2002, p. 29, tradução minha) .

Algumas das principais bases para o estudo do som no audiovisual são as obras de Michel Chion, Pierre Schaeffer, Rick Altman e Mary Ann Doane. Para efeitos desta dissertação procuramos autores que transcorrem sobre essas bases desenvolvendo um pensamento mais direcionado aos temas que nos interessam, ou seja, a participação do som na geração dos relatos.

\section{1 Imagem e som}

Assim como nos manuais de roteiro, nos textos sobre o som como elemento narrativo a imagem é, via de regra, o ponto de partida. Por isso, começaremos tratando de como tais textos estabelecem relações entre imagem e som. Ressalto que a ideia não é opor som e imagem, nem considerá-los contrários, nem entender que na escrita do roteiro precise haver uma competição entre os elementos auditivos e visuais. Mas como o vocabulário do roteiro, da crítica, da teoria sobre cinema está impregnado por termos relacionados à imagem, é importante ir às origens 
dessas formas de nomear para entender se elas se relacionam com o fato de que o som como elemento expressivo e narrativo ainda é pouco explorado no cinema narrativo de ficção.

Michel Chion afirma que "a função mais difundida do som no cinema é aquela que consiste em unificar o fluxo das imagens, em enlaçá-las, por um lado, no nível do tempo [...] e por outro lado no nível do espaço" (CHION, 1990, p. 44, tradução minha). O cineasta e compositor francês Michel Fano segue uma linha parecida, ao falar do som como "certificado de presença da imagem; ou seja, vemos algo e há um som que acompanha, mas é uma forma de relacionar o som passivamente não com a história, e essa foi a forma a que o cinema norteamericano nos acostumou" (LABRADA, [201-], p. 104, tradução minha). A partir destas considerações podemos concluir que o cinema narrativo encontra no som uma ferramenta que potencializa seu caráter realista.

Traçar um breve e resumido histórico da introdução técnica do som no cinema nos ajuda a entender como se estabelecem as primeiras relações entre som e imagem no cinema sonoro. É importante observar que essas relações já existiam no cinema silencioso, que supunha o som em suas sequências. Concordamos com a afirmação de que "o cinema é audiovisual, nunca foi mudo [...]. Sempre houve uma perspectiva entre os grandes [cineastas] para incorporar o som ao universo significante do filme.” (ROJAS, 2016, p. 95, tradução minha)

"O advento do som introduziu no espaço cinematográfico inúmeras possibilidades de jogos com a imagem. Ordinariamente considerado como detalhe na representação fílmica, o som, assim como a imagem, participa da figuração diegética, tanto quanto o enredo do filme." (FLÔRES, 2013, p. 24) Além dessa ampliação de possibilidades, das quais trataremos mais adiante, a introdução do som encontrou dificuldades relacionadas a fatores tecnológicos que foram acompanhados de imprecisões terminológicas, ou falta de vocabulário adequado para referências à expressão sonora. "O desenvolvimento mais acelerado das tecnologias de imagem em relação ao som pode ter sido uma das causas, como aponta Rick Altman, para um discurso que tenta situar este como subordinado àquela." (CASTANHEIRA, 2012, p. 93) Interessa-nos, em primeiro lugar, entender esse caráter de subordinação do som à imagem para então encontrar as possibilidades de transcendê-lo e ampliar as funções dos efeitos sonoros e ruídos, diálogos e músicas em obras audiovisuais. 
$\mathrm{O}$ audiovisual em geral, e o roteiro em específico, tomam emprestados termos de outras artes e áreas do conhecimento para compor seu vocabulário e suas teorias. O conceito de personagem, por exemplo, remete à literatura e ao teatro; a ideia de cena vem também do teatro, enquanto a de sequência provém da fotografia. Os gêneros cinematográficos têm suas raízes na literatura, na poesia e no teatro; a linguagem usada para nomear planos, enquadramentos, etc. se origina nas artes plásticas e na fotografia still. Para escrever um roteiro, seu autor conta apenas com a palavra para descrever imagens e sons, buscando por meio dela uma aproximação ao universo audiovisual, pois é impossível escrever imagens e sons.

No caso do som, alguns autores defendem a ideia de que um dos fatores que influenciaram na subordinação do som à imagem ao longo da história do cinema é um desenvolvimento tecnológico posterior e o emprego de termos dos meios visuais e fotográficos para nomear e descrever as ferramentas sonoras. Outros, como Doane, encontram explicações na própria lógica de produção de filmes, que invisibiliza som e montagem:

Doane desenvolve uma hipótese interessante para a compreensão da supremacia do visível sobre o sonoro no cinema e nas análises teóricas: segundo ela, as práticas estéticas dominantes de invisibilidade da edição e da mixagem procuram anular o trabalho (ideologia burguesa) e tornam a trilha sonora algo tão natural que quem assiste ao filme pensa que "emana" da imagem, afastando assim a compreensão da heterogeneidade material do cinema. "O som é algo que é acrescentado à imagem, entretanto, é a ela subordinado - ele atua, paradoxalmente, como um suporte 'silêncioso'." (FLÔRES, 2013, p. 92)

Altman, por sua vez, defende a origem terminológica como um dos fatores que fazem com que o som esteja quase sempre subordinado à imagem nos filmes:

Para Altman, a própria condição precária das tecnologias de captação e registro de som para o filme em suas primeiras décadas levou ao desenvolvimento mais sofisticado de procedimentos e, consequentemente, de terminologias ligadas ao campo visual. Assim, conceitos e termos como plano, corte, ponto de vista, foco etc. são ligados a tecnologias do cinema como câmeras, lentes, moviolas etc., mas dificilmente se originaram ou se aplicam perfeitamente ao campo sonoro. (CASTANHEIRA, 2012, p. 93)

Segundo Flôres, Altman atribui a perpetração indireta do "ceticismo dos primeiros cineastas em relação ao som" ao fato de "a crítica e a teoria cinematográficas ainda permanecerem estreitamente ligadas à imagem; ele também acredita que 'a fonte do domínio 
atual da imagem relaciona-se estreitamente ao vocabulário desenvolvido por críticos cinematográficos durante três quartos de século', estando toda a terminologia orientada para a câmera" (FLÔRES, 2013, p. 40).

Em entrevista ao crítico Víctor Fowler Calzada e ao jornalista Dean Luis Reyes, o projetista de som cubano Jerónimo Labrada trata da bibliografia sobre cinema em geral, afirmando que podemos encontrar em bibliotecas

grandes tratados sobre a historia do cinema, sobre a direção, a fotografia - há algumas analogias entre a fotografia e a pintura que facilitam um pouco a análise -, e, em geral, em todos os outros campos relacionados à literatura, à narração, à foto, à pintura: em todos esses campos há um desenvolvimento teórico grande, que permite avançar teorias, especulações teóricas... No caso do som isso é mais complexo; buscamos nas bibliotecas e, quando chega o capítulo do som, há quatro páginas nas quais são feitas descrições técnicas [...] mas realmente ninguém faz um aprofundamento teórico dessas funções expressivas do som. (LABRADA, [201-], p. 113, tradução minha)

É interessante notar como essa questão da nomenclatura se transporta para a escrita de roteiros: também os roteiristas contam com um vocabulário mais amplo relacionado à imagem do que o vocabulário para descrever o som. "Mesmo que pareça óbvio, é imprescindível partir da ideia de que o cinema é um meio audiovisual, ou seja, que envolve tanto a imagem como o som e também é necessário considerar que os diferentes 'tipos' de cinema se valem mais ou menos do som." (SAITTA, 2002, p. 13, tradução minha) O roteirista precisa estar consciente dessas duas coisas: o caráter audiovisual do cinema e o tipo de filme que se propõe a escrever, para que o uso mais ou menos complexo do som seja algo presente desde a escrita do roteiro.

Além desse "empréstimo" de terminologia, que segundo Castanheira revela uma "tensão mal resolvida" entre som e imagem (CASTANHEIRA, 2012, p. 94), há um segundo fator que gera conflito, ou pelo menos contraste, entre o mundo sonoro e o mundo das imagens no campo audiovisual. Trata-se da busca de equivalentes terminológicos e consequentemente instrumentais para a descrição dos elementos que compõem as narrativas. Assim, ao tentar um equivalente a ponto de vista, cunha-se o termo ponto de audição. Essa separação pode gerar um distanciamento entre som e imagem, quando o mais interessante seria encontrar algo como um ponto de percepção, ou de "audiovisão", que englobasse ambos os aspectos, que finalmente são recebidos simultaneamente pelo espectador. Castanheira afirma que "devemos compreender as diferenças 
entre a apreensão do mundo através do som e aquela através da visão. São experiências distintas, muito embora não devam ser colocadas em polos opostos como vem sendo feito ao longo dos anos." (CASTANHEIRA, 2012, p. 98)

Falar de um ponto de audição como que para fazer um paralelo ao ponto de vista, pura e simplesmente, não resolve a questão de melhor definir um deslocamento da percepção acústica em determinados movimentos do filme. O próprio Altman e Michel Chion admitem que se trata de uma adaptação não satisfatória. Este último, inclusive, chega a sugerir outra nomenclatura: "não é frequentemente possível falarse de um ponto de audição no sentido de uma posição precisa no espaço, mas, em vez disso, de um lugar de audição, ou mesmo zona de audição". (CASTANHEIRA, 2012, p. 94)

A pesquisadora Virgínia Flôres se propõe a entender a participação do som no relato buscando as ocasiões em que ele transcende o papel de certificado de presença da imagem. Segundo a autora, "o estudo de pequenos desarranjos ocasionados pelo sonoro nos filmes [...] induz a sondar com mais detalhe os procedimentos de articulação entre essas duas matérias [som e imagem], supondo que podem ir além de uma simples relação de ancoragem, ou seja, de sincronismo" (FLÔRES, 2013, p. 28). A autora acrescenta que "um som torna-se adequado quando ultrapassa a questão de realidade sonora, de uma suposta fidelidade a alguma coisa - no caso, ao que se vê - e passa a figurar a questão de transmissão de sentimentos, de ideias" (FLÔRES, 2013, p. 32).

Voltando ao processo de trabalho anunciado por Doane, e ainda na busca por um caminho de paridade entre imagem e som, é interessante levar em conta o pensamento desenvolvido por Saitta. Segundo o autor, "Supõe-se que uma sequência será sonorizada porque necessita o aporte narrativo-expressivo do som, e não o contrário. Não é a trilha sonora a que deve ser sustentada pela imagem, mas o contrário, é o som o determinante das conotações da imagem audiovisual." (SAITTA, 2002, p. 51, tradução minha) Portanto, o que propomos não é uma inversão de papéis, ou uma troca, da imagem pelo som na composição audiovisual, mas formas de interação em que o som ganhe mais importância. Acreditamos que o caminho para isso está na inclusão de abordagens dos elementos da trilha sonora a partir da escrita do roteiro. Nesse sentido, a seguinte pergunta elaborada por Saitta sobre a separação entre bandas de imagem e bandas de som nos parece pertinente: "deveríamos continuar considerando-as duas bandas? Não seria mais oportuno propor a relação funcional entre os diferentes níveis de informação independentemente de se 
estes são decodificados pela vista ou pelo ouvido? Não seria o momento de dar ao som o espaço necessário para colocar em evidência seu poder narrativo, expressivo e estrutural nas linguagens audiovisuais?" (SAITTA, 2002, p. 51, tradução minha)

Como transpor essas propostas ao roteiro? Talvez o primeiro passo seja o estudo, por parte dos roteiristas, das possibilidades do som e de sua expressividade no filme finalizado.

\subsection{O roteiro como ferramenta de trabalho: quando e onde o filme começa a} soar?

Alguns autores defendem a ideia de que o desenho de som deve começar cedo no processo de realização de um filme, ou seja, no roteiro. "No cinema, sempre existe a imagem visual, sua montagem, e tudo o que está ligado a ela através de um roteiro, principalmente os diálogos. Estes são os pontos de partida da banda sonora, os primeiros elementos sonoros de uma trilha." (FLÔRES, 2013, p. 52) Flôres cita as obras de Jacques Tati como exemplos de filmes em que o som é pensado como ponto de partida para a criação do relato e estão não só na base dos roteiros; nesses casos, as "situações dramáticas surgem a partir de dados sonoros" (FLÔRES, 2013, p. 80). Além dos filmes de Tati, há outros exemplos clássicos de filmes que têm o som como ponto de partida para gerar situações dramáticas. Em M., o Vampiro de Dusseldorf (1931), há um elemento argumental relacionado ao som a partir do qual a trama é desenvolvida. O personagem do assassino tem o hábito de assobiar uma musiquinha (um trecho da música Peer Gynt de Edvard Grieg), e é através do som de seu assobio que ele é descoberto. Esta ideia só pode ter surgido na etapa de roteiro, uma vez que é consubstancial ao relato e sem ela o mesmo não faz sentido.

Apesar de ser uma informação pouco difundida nos manuais de roteiro e em estudos sobre o som como papel expressivo, é importante ressaltar que,

assim como a fotografia, a direção de arte, a montagem, o elenco, a decupagem se ocupam de construir a imagem a partir do roteiro, também os sons devem ser planejados. Eles podem ser usados com fins narrativos, naturalistas ou realistas, expressivos e em contraponto, impressionistas, hiper-realistas, autorais, como se desejar. O importante é ter clara uma direção, um partido estético que conduzirá uma série de escolhas que serão feitas por várias pessoas que participam na construção de um filme e de uma trilha sonora. (FLÔRES, 2013, p. 101) 
Ao analisar os fatores construtivos do som, e sua relação com fala, música, natureza ou artefatos, Saitta observa que é importante considerar o que chama de "problemas de 'roteiro': o que se pode contar e o que não se pode contar com o som" (SAITTA, 2002, p. 34, tradução minha). É interessante observar que esta é uma pergunta que pode ser feita pelos roteiristas no momento da escrita, da criação, da estruturação do relato. Já existe uma ideia bastante disseminada e difundida pelos manuais de roteiro, que estimulam a contar com imagens, ao invés de explicar com diálogos ou narrações em off. E se o mesmo esforço fosse feito com relação ao som além das palavras?

Saitta fala em termos de valor do som: "pretende-se que os sons tenham sempre um maior valor narrativo e/ou expressivo, um valor agregado, imprescindível quando se pretende dar à sequência sonora um valor construtivo" (SAITTA, 2002, p. 35, tradução minha). Ora, se estamos falando de valor construtivo, estamos falando de valor argumental. O som como valor argumental só pode originar-se na etapa de criação do relato, ou seja, durante a escrita do argumento e do roteiro. É nesta etapa que o roteirista desenvolve os elementos dos quais lançará mão para contar uma história, e é a partir dele que deveria começar a pensar a trilha sonora do filme. Recursos sonoros pensados como elementos construtivos e argumentais tornam-se pilares para o relato: se forem mudados, o relato também se transforma; seu sentido muda.

Como vimos, o roteiro, no cinema clássico narrativo, é um ponto de partida para o trabalho de toda a equipe. É nele que se estrutura o relato. Sobre esse texto recai a responsabilidade de contar uma história a partir de palavras que serão transformadas em imagens e sons. Para que esse texto seja o ponto de partida para sons expressivos, é preciso levar em conta que não só as palavras (diálogos) ou as imagens são portadoras de informação; ações, gestos e sons também.

Em sua conferência "Escrita de roteiros para o som", o projetista de som norte-americano Randy Thom faz uma provocação:

É uma teoria bastante radical no mundo do cinema; a de que o projeto de som não é realmente algo que deveria acontecer apenas na pós produção de um filme ou vídeo, mas a de que o projeto de som precisa acontecer muito antes, começando pelo roteiro. E se não começar pelo roteiro, que seja nas reescritas do roteiro, ou pelo menos cedo no processo de produção, onde ainda há tempo para que as ideias sobre som se infiltrem e tenham um efeito criativo em todos os outros elementos. (THOM, 2011, p. 3, tradução minha) 
Seria o caso, então, de trazer o projetista de som para a criação do roteiro, ou para os momentos de leitura do mesmo? Ou bastaria uma sensibilização do roteirista para incluir a perspectiva sonora em seu processo criativo?

Saitta afirma que

o roteiro pode ser em origem somente um texto, mas logo será necessário, em algum sentido, abandoná-lo. Haverá que transformar esse roteiro em outro em que as diferentes imagens suscitadas por diferentes linguagens ocupem seu espaço, seu lugar na trama multimídia. Dito de outro modo, será necessário ver que parte, que aspecto da história se contará com imagens, com movimentos de câmera, com enquadramentos, com luzes, com sujeitos, com objetos, com gestos, com sons, com música, etc. (SAITTA, 2002, p. 38, tradução minha)

$\mathrm{O}$ autor sugere que o roteiro literário contém o que queremos dizer e o roteiro técnico incluiria o como, a forma. Mas será que só no roteiro técnico é possível uma escrita que dê indicações sobre o som? Talvez as indicações técnicas sim, mas se queremos que o som seja um elemento construtivo do relato ele precisa aparecer antes do roteiro técnico, ainda que de forma subentendida ou invisível, sugerida. Senão, não haverá elementos de base que possibilitem uma descrição técnica do som que vá além da decisão de captar o som de uma maneira ou de outra. Ou melhor, que a decisão de captar o som de uma maneira ou de outra, ou de não captá-lo, seja uma decisão embasada em argumentos narrativos, expressivos e construtivos.

O próprio Saitta corrobora esse pensamento ao afirmar que "o texto é imprescindível, mas em cada caso se deverá considerar o que é em realidade o imprescindível: o que queremos contar, o que é conveniente dizer com palavras, e o que com outro meio" (SAITTA, 2002, p. 38, tradução minha). Ou seja, tudo é uma questão de tomadas de decisões desde o nascimento do relato. E para que o roteirista possa tomar decisões sobre o som precisa estar atento às possibilidades do sonoro, e conhecê-las.

Vemos, então, que um texto não só é portador de uma ideia, de um pensamento, de um significado; é além disso, portador de relações afetivas, plásticas e sonoras. 'O texto deve 'soar', tem que ser concebido como uma 'música'; só assim poderá produzir motivações, associações, sensações, imagens de grande riqueza expressiva; só assim poderemos transformá-lo em um objeto de sedução." (SAITTA, 2002, p. 39, tradução minha)

Mas o que é um texto que "soa"? 
Uma das respostas pode ser o que Thom fala sobre o espaço onde ocorrem as ações e narrações. "Me pergunto por que poucos roteiristas e diretores pensam em escolher locações baseados nas possibilidades sonoras que elas oferecem." (THOM, 2011, p. 9, tradução minha)

$\mathrm{O}$ roteiro pode, e deve, ser o momento em que pensamos como soam as locações e o espaço em geral, os personagens (em seus gestos, movimentos, vozes), os objetos. Além disso, o roteiro é o documento onde se podem descrever sons que complementem o discurso e geram significados, sejam tais sons realistas ou não, diegéticos ou não.

\subsection{0 diálogo}

Como vimos, o diálogo é um dos elementos que compõem a trilha sonora. Chion defende a ideia de que o cinema é "verbo-centrado", conceito que ele define como:

Fórmula do cinema falado dito clássico na qual a mise-en-scène, o jogo dos atores, a concepção dos sons e das imagens são conscientemente ou inconscientemente orientados pelo objetivo geral de que se escutem os diálogos (geralmente abundantes), como a ação, fazendo dele o centro - frequentemente invisível - do jogo de cenas, de efeitos de montagem, de iluminação, etc., destinados a facilitar a escuta e a dramatizar o conflito, apagando a percepção do diálogo como tal. $\mathrm{O}$ espectador - consensual - do cinema clássico verbo-centrado não se surpreende ao ouvir um fluxo de diálogos em torno do qual tudo é organizado: é convencido a assistir uma ação complexa na qual o diálogo é apenas uma parte, que poderia ser quase insignificante. $\mathrm{O}$ cinema verbo-centrado muitas vezes usa o entrelaçamento e a alternância dito/mostrado. (CHION, 1990, p. 225-226, tradução minha)

As palavras faladas são o pilar de sustentação da maioria dos relatos, pelo menos no cinema narrativo de ficção. As funções do diálogo são variadas no que diz respeito à construção da dramaturgia do roteiro e do sentido do relato. Um diálogo pode ser informativo: pode ser informativo-histórico (quando informa sobre algo que já aconteceu); pode revelar características biográficas, sociais e culturais dos personagens; pode fazer o relato avançar quando são diálogos de ação, réplicas (ROJAS, 2016, p. 26-27). Aqui, daremos atenção ao que diz respeito ao caráter sonoro do diálogo.

Flôres afirma que "o primeiro 'som' pensado em um roteiro cinematográfico é o texto que será proferido. Esse texto poderá ser projetado em forma de comentário, narração, pensamento, discurso ou, ainda, em forma de diálogo, portanto será transformado em emissão acústica, em 
voz." Ao escrever diálogos, o roteirista não só está transmitindo informações que fazem com que a trama avance ou que revelem características históricas dos personagens. As palavras escritas em diálogo depois serão ditas em determinado ritmo, com determinada intensidade e com determinado tom de voz. Até que ponto cabe ao roteirista interferir nesses elementos? Mais uma vez, voltamos ao nível do argumental. Se é imprescindível para o sentido do relato que o personagem tenha a voz fina, ou seja gago, ou tenha um sotaque, isso deve estar escrito no roteiro. Se o diálogo deve soar naturalista, faz parte da pesquisa do roteirista construí-lo para que assim o seja.

Segundo Flôres, o diálogo é um dos instrumentos da narrativa nos filmes de ficção e também deve ser um objeto de representação. A autora relaciona o diálogo com o todo da obra audiovisual e define sua importância: "Sem o diálogo, e com ele a vivacidade narrativa, o cinema perde sua unidade; definir o lugar do verbo, medi-lo proporcionalmente em relação ao silêncio, é uma parte e um ato da mise-en-scène." (FLÔRES, 2013, p. 126)

Podemos recuperar, por meio do que diz Fano, elementos da história do cinema sonoro, para entender o que ele chama de "tirania" da palavra nas obras audiovisuais:

Qual a diferença, então, entre [o filme sonoro e] o filme mudo, onde o espectador excitava "virtualmente" os barulhos gerados pela ação? A palavra, é claro, que ganhará sozinha o poder nos primeiros anos do filme sonoro. Um poder terrivelmente forte a cuja tirania que ainda hoje estamos submissos. Se queremos ver os atores falarem em um ambiente sonoro fiel à ação, é suficiente ouvir, não há nada para escutar. (FANO, 2005, p. 2, tradução minha)

Vimos, na análise dos manuais de roteiro, que muitas vezes o "par" da imagem não é a trilha sonora como um todo, mas o diálogo. Existe uma ênfase, em parte motivada pelas origens teatrais do cinema, ou por uma intenção de distanciamento da teledramaturgia, em priorizar a imagem, o buscar a imagem para contar. É importante que um roteirista seja consciente, além disso, de que um roteiro que prioriza o diálogo dá menos espaço a outros tipos de som.

É frequente que um diretor me procure com uma cena que é praticamente de diálogo contínuo e me pede que encaixe de alguma forma algum projeto de som nela. Isso nunca funciona realmente, porque há algo a respeito da voz humana que atrai outros humanos a simplesmente terem que ouvi-la. Uma voz quase sempre terá precedência com relação a outros sons, e mesmo se você quase não consegue entender o que está sendo dito, você usará toda sua habilidade de audição para tentar ouvir a voz e perceberá pouco ou nada além, não importando o quanto esteja 
acontecendo ao redor. Constantemente converso com diretores que estão projetando cenas que esperam que sejam fortes em termos de som e sugiro que eles pelo menos mantenham o diálogo o mais esparso e eficiente possível. Esta é uma das principais técnicas para abrir as portas para o desenho projeto de som. (THOM, 2013, p. 107, tradução minha)

O relato da experiência de Thom é útil para aqueles que se dedicam à escrita de roteiros e de diálogos, pois conecta roteiro e pós-produção, deixando claro que fazem parte de um mesmo processo.

Podemos dizer que o texto - que é uma das cadeias linguísticas que compõem a trilha sonora - só terá possibilidade de ser articulado com o resto do material sonoro quando forem valorizadas as qualidades que vão além de seu significado. Só então poderemos pensá-lo como sequência sonora, como uma cadeia articulada de sons. Deverá pensar-se assim desde o momento em que se cria o roteiro, e deverá cuidarse no momento da filmagem, na dublagem e na montagem de pistas. (SAITTA, 2002, p. 39, tradução minha)

Saitta, além de articular a escrita dos diálogos ao processo de produção do som, chama a atenção para os valores sonoros do diálogo, ou seja, para o som, o ritmo das palavras que serão pronunciadas em determinados tons e timbres pelos atores. Labrada, por sua vez, convida os roteiristas e escreverem textos que tenham sentido não só literário, mas também musical, levando em conta que o texto dos diálogos é um texto que será dito em voz alta e precisa transmitir, além de informações, emoções. Segundo Labrada, o escritor cubano Alejo Carpentier falava muito sobre a dificuldade de

traduzir o texto literário ao diálogo falado. O roteirista tem que fazer esse exercício de escrever textos sabendo que serão ditos, interpretados, onde os silêncios, as pausas, as mudanças de intensidade, a voz, têm um papel muito importante; com a ideia de que é mais importante como se diz do que o conteúdo do que está sendo dito. (LABRADA, [201-], p. 111-112, tradução minha).

\subsection{Música e metáfora musical}

É possível destacar três pontos importantes referentes à música mencionados por autores que estudam o papel narrativo e expressivo do som nas obras audiovisuais. O primeiro deles, mais consensual, é o fato de que a música é um elemento integrante da trilha sonora, e deve ser pensado e considerado em conjunto com os outros sons dos filmes. O segundo é o fato de que a música deve ser levada em conta, assim como os outros sons, desde as etapas iniciais da 
construção do relato, ou seja, desde o roteiro. O terceiro é algo mais sutil, também encontrado nos manuais de roteiro: a música (produto final) e a composição musical (processo de produção) são consideradas análogas ao filme (produto) e à construção, ou composição audiovisual (processo de produção).

Durante muito tempo, desde o surgimento do cinema em 1895 e o início do cinema sonoro em 1926, a montagem de imagens e a música tiveram a função de transportar o espectador e conduzi-lo a determinadas conclusões ou interpretações sobre suas narrativas. Alguns autores destacam algumas dessas funções da música: unificar as imagens, envolver cada espectador na sua relação com o filme, embalar a assistência, ajudar a fazer o espectador sonhar, sublinhar pontos fortes da ação, identificar características dos personagens e, sobretudo, criar uma temporalidade de diegese. (FLÔRES, 2013, p. 139)

Saitta também trata das funções da música nos filmes. Em resumo, essas funções são: substitutiva (música substitui uma situação argumental ou parte dela); emolduradora (música cria uma sensação sem aludir ao visível); comutativa ou transformadora (música passa de uma situação a outra); de enlace (música preenche um silêncio ou une duas situações diferentes); de complementaridade (música cria uma situação expressiva); de independência (equilibra uma situação psíquica por seu caráter sublimador); associativa (ativa esquemas descrevendo ou ilustrando); tensional (altera a tensão de uma sequência); introdutória (causa determinada predisposição no espectador); delimitativa (determina o espaço de uma situação); de fundo (acompanha uma sequência). Segundo o autor, "estas funções, em geral, devem estar previstas desde o roteiro, o que nem sempre acontece. Em geral, a música aparece depois da montagem de pistas, momento no qual já se pode fazer muito pouco nesse sentido." (SAITTA, 2002, p. 44)

Flôres afirma que "uma trilha sonora engloba todos os sons de um filme, e, deste ponto de vista, deveria ser pensada como uma composição e uma orquestração" (FLÔRES, 2013, p. 139). Mais adiante, a autora completa esse pensamento, afirmando que "a música pode ser pensada no cinema em dois sentidos: como um elemento integrante da trilha sonora, mas também como o princípio composicional que rege a inclusão e escolha de todos os sons de um filme e até mesmo a montagem de imagens" (FLÔRES, 2013, p. 140).

Nessa mesma linha, podemos observar o conceito de continuum sonoro desenvolvido por Fano: ao tratar do filme Os amantes crucificados (1954), de Kenji Mizoguchi, o francês descreve a "extraordinária continuidade que une os eventos sonoros, idiomáticos [...] e musicais, que 
permitem à escuta explorar sem rupturas os três domínios. Assim como o olho não pode dissociar, na imagem, cenário, figurino, iluminação, etc. Ele descobriu um todo, uma coerência, uma nova conexão entre o visto, o ouvido e o significado; entre a imagem, som e sentido." (FANO, 1986, p. 2, tradução minha) Em outra ocasião, Fano assinalou que nesse filme "ruídos sincrônicos ou em off, pontuações de percussões parecem estar escondidas não só na história, mas também na língua; o todo tece com a imagem uma trama audiovisual de rara complexidade"

(FANO, 1975, p. 3, tradução minha). É interessante como, ao definir o continuum sonoro, o autor questiona a separação entre sons musicais e barulho, afirmando que "tudo é música ou nada o é. E se um critério de distinção deve ser retido, é precisamente o da diferença de espessura semântica, a partir da qual e em função da história, o continuum sonoro irá se edificar." (FANO, 1975 , p. 3, tradução minha)

Esse princípio sugerido por Flôres e desenvolvido por Fano segundo o qual todos os sons do filme compõem uma continuidade pode ser visto como mais uma razão para estabelecer as bases sonoras do relato a partir da escrita do roteiro, ou pelo menos prever, no texto, espaços nos quais o som pode se expressar.

\subsection{Qual a função do objeto roteiro? Como se escrevem as indicações sonoras?}

Como vimos no Capítulo 1, alguns autores de manuais recomendam o uso de destaque, negrito ou caixa alta para escrever as informações sonoras do roteiro. Mas indicar a presença do som significa necessariamente que esse som tem valor narrativo ou expressivo? Ou essa indicação pode ser redundante, e apenas corroborar a ideia de que o som é um certificado de presença da imagem? Por exemplo, se o roteirista escreve que "João pressiona a buzina do carro e se escuta o SOM DA BUZINA", isso quer dizer que está escrevendo um roteiro sonoro? Até que ponto escrever o som é descrever o que ouvimos a partir da imagem?

Para que um roteiro possa ser considerado sonoro, não é suficiente apenas citar os efeitos de som no roteiro, mas contemplar a ideia de som como elemento construtivo. Um dos caminhos é considerar, ao longo da escrita, a ideia de ponto de vista, ou, para ser mais preciso, de audiovisão, pensando essa ideia não só como um conceito físico, não só como o lugar físico de onde se vê e se escuta a ação, mas também considerando a subjetividade desse ponto. 
Ao analisar diferentes versões do roteiro de Apocalypse Now, Thom observa que, apesar de a versão escrita pelo roteirista John Milius apresentar indicações sobre o som (insetos, etc.), é só na versão de Coppola que o som "ressoa", pois, mais que descrever o som, o realizador incorpora a ele um "ponto de vista", ao afirmar que as palmeiras "são vistas como se estivessem em um sonho". É a partir do desenvolvimento do conceito de ponto de vista que Thom justifica o caráter sonoro do roteiro, ao estabelecer o que entende como ponto de vista: "é a ideia de que o que nós, a audiência, estamos experimentando é o que está sendo experimentado por personagens na tela" (THOM, 2011, p. 04, tradução minha).

Essa informação, segundo Thom, é o que permite elaborar toda a sequência como ela foi elaborada. O curioso é que aí o som não é indicado explicitamente; ele faz parte de certa escrita invisível. Mas é o estabelecimento desse ponto de vista que permite toda a construção sonora da sequência inicial do filme: "Coppola decidiu não seguir o filme de guerra mais ou menos direto de Milius, mas resolveu contar a história através do ponto de vista dos soldados americanos na guerra do Vietnã. Foi esta decisão que abriu portas, permitindo que Walter Murch fizesse o trabalho magnífico que ele e sua equipe fizeram." (THOM, 2011, p. 5, tradução minha)

Assim, a sugestão do som é mais do que sua descrição, passa por decisões sobre ponto de vista e por essa ideia de que o roteiro "abre portas" para que na continuidade das atividades de confecção do filme os sons possam ir entrando. Muitas vezes é mais importante a sugestão do som do que sua descrição.

A experiência e o sujeito estarão sempre juntos no ato de fruição. Nenhum filme poderá ser escutado, pelo espectador ou pelo crítico, sem ser a partir de um ponto de vista subjetivo. Os sentidos dessa linguagem serão criados pelo sujeito, com toda bagagem cultural e temporal que lhe são peculiares. (FLÔRES, 2013, p. 70)

Além desta noção sobre o ponto de vista e as intenções com relação às sensações a serem transmitidas pelo relato, é importante que o roteirista também tenha à disposição um arsenal mínimo de ferramentas relacionadas ao mundo da construção da trilha sonora para obras audiovisuais, pois "será necessário um conhecimento sério do som para uma eficaz construção do mesmo. Ninguém dispõe daquilo que ignora.” (SAITTA, 2002, p. 37)

Uma das primeiras características da composição audiovisual que os roteiristas devem levar em conta é o caráter físico da captação de som e imagem, pois é graças ao "recurso da 
separação do suporte que o som dos filmes pode ser manipulado independentemente da imagem, trazendo infinitas possibilidades criativas e perceptivas de relações entre esses dois elementos" (FLÔRES, 2013, p. 36). No cinema clássico, no entanto, os sons

se relacionam muito mais diretamente com as imagens, numa relação vertical, do que com outros sons que se ligam numa sucessão (relação horizontal). Este é o paradigma do cinema sonoro. Um cinema que se beneficia da separação entre o ato técnico do fazer e o sentido estético de união alcançado pelo produto final durante a projeção das duas bandas. (FLÔRES, 2013, p. 50)

Então, por um lado, o cinema narrativo se sustenta, em certa medida, no fato de que o som é, sim, um certificado de existência da imagem. Mas por outro lado todo o corpo do filme contém em si a possibilidade de que o som transcenda essa função, ou que tenha funções além daquela que a necessidade realista do cinema lhe atribui.

Realismo é uma palavra associada frequentemente à chegada do som sincrônico ao cinema. Contudo, aparentemente contradizendo a filosofia do som direto, essa impressão de realismo está ligada à manipulação independente de cada matéria do cinema (som e imagem), a qual oferece o meio de recompor de forma artificial, a posteriori, o som direto diegético. (FLÔRES, 2013, p. 37)

Assim sendo, as instâncias do som e do roteiro na cadeia de produção do filme podem não coincidir no que diz respeito à feitura da obra, mas devem coincidir no que diz respeito ao pensamento, à concepção do projeto de um filme. Uma das possibilidades para buscar na trilha sonora um componente expressivo da narrativa é considerar sua potencialidade de não necessariamente ser atrelada a imagens: “o campo de pesquisa e de atuação dessa trilha aumenta consideravelmente quando há invisibilidade da fonte sonora, quando o campo de atuação do sonoro se torna principalmente off (em relação à tela)" (FLÔRES, p. 52).

Para pensar que elementos sonoros um roteirista pode levar em conta na composição de um argumento ou de um roteiro é interessante recuperar a ideia de Thom sobre a possibilidade de escolher as locações de acordo com seu potencial sonoro. Isso não significa que os lugares onde transcorrem as ações precisem ter algum som especialmente particular. Muitas vezes é suficiente ouvir o que o lugar pode oferecer em termos sonoros e aproveitar esses recursos na construção do relato. É o que acontece, por exemplo, no filme Hiroshima meu amor (1959). A personagem francesa tem recordações sobre seu passado em Nevers, e um elemento que pontua o espaço sonoro do local é o sino da igreja. As badaladas são escutadas por primeira vez após o diálogo 
inicial do filme, quando o personagem japonês pergunta à personagem francesa se eles voltarão a se encontrar. Entre a pergunta do primeiro e o "Não" da segunda está o som do sino, que remete à memória da personagem. Para que este som pudesse estar ali e tivesse espaço para acontecer foi preciso pensá-lo antes. O som do sino, depois, é usado de forma diegética nos flashbacks da personagem. Depois, quando ela caminha por Hiroshima, escutamos o som do mesmo sino, agora de forma extradiegética, como se estivéssemos metidos na mente da personagem. Segundo Fano, Hiroshima mеи amor é um exemplo de filme "onde o discurso sonoro, cruzando os dados apenas do realismo, desata a narrativa auditiva da narrativa visual para reorganizá-la em novas funções realmente contrapontísticas - ligadas à estrutura poética do filme” (FANO, 1986, p. 2).

"Por Paisagem Sonora, segundo a perspectiva de [Murray] Schafer, poderíamos entender o conjunto dos diversos sons ambientes que nos envolvem cotidianamente." (CASTANHEIRA, 2012, p. 99) Esta atenção ao som dos espaços escolhidos para o desenvolvimento de determinada trama pode estender-se aos sons do cotidiano, aos sons que podem ser emitidos pelos personagens e pelos objetos de cena, aos sons que remetem ao universo tratado pelo roteiro e até mesmo a sons que completam ou contradizem esse universo.

Um som se torna adequado, bom, quando ultrapassa a questão de realidade sonora, de uma fidelidade suposta a alguma coisa, e passa a figurar mais sobre a questão de transmitir um sentimento, uma ideia, através de sua matéria. Um som restituído se torna suficientemente bom quando dá aos objetos, aos personagens, às situações representadas nas imagens uma qualidade, um peso, uma densidade que não poderiam ser encontrados sem ele ou apenas com o som direto do filme. (FLÔRES, 2013, p. 129)

Os filmes, de qualquer maneira, vão soar. E os sons terão significado. Não seria interessante, então, no momento de sua construção inicial, ou seja, no roteiro, levar em conta conscientemente que sons produzem sentido?

Labrada defende a ideia de que o som dos filmes tem uma relação estreita com a narração, e "os roteiristas precisam ter uma consciência forte disso, porque se no roteiro não estiverem esses elementos sonoros que fazem parte da história, já estamos começando mal" (LABRADA, [201-], p. 109). A partir de sua experiência como professor, projetista de som e espectador, Labrada constata que os roteiros costumam ser "mudos", e o único que soa é o diálogo. Assim, 
nesses casos, se vemos um filme legendado sem o som não perdemos nenhuma informação importante do relato, pois nada depende do som para fazer-se entender.

As pessoas se acostumam a escrever roteiros mudos, a narrar histórias que não soam, e isso é clássico no cinema norte-americano, no latino-americano, no europeu; o único som nos roteiros são os diálogos. Todos os anos me encontro aqui [na EICTV] com os alunos de roteiro e falo para eles sobre estas coisas, pois do contrário, quando se faz o roteiro técnico, como não há som, se planeja resolvê-lo visualmente, e depois o editor recebe esses planos que foram feitos com um sentido muito visual e não tem outra opção a não ser montar a história assim, de maneira que, quando chega o momento de fazer o som, temos uma sucessão de planos que não necessitam dele para que se entenda o que está acontecendo. O que acontece aqui? Buscar um ambiente que seja bonito, recriar uns passarinhos, se é de noite um grilo, uma rãzinha, um cachorro que late, elementos que estão desligados da historia, que estão criando uma atmosfera, uma sensação de dia, de noite, de trânsito, de campo, mas que não estão realmente acrescentando nada à história. Esses filmes podem ser vistos com a televisão no volume mínimo, você lê as legendas e não acontece nada, você vê o filme e não perde nada importante. Quando alguns roteiristas me dizem que "o roteiro é uma obra literária", digo que o som está na literatura. Então mostro uma longa lista de obras de poesia, contos, romances, que são obras puramente literárias nas quais o som desempenha um papel importante. (LABRADA, [201-], p. 109-110, tradução minha)

Voltamos, então, a pensar nos instrumentos com os quais o roteirista pode contar para escrever textos que venham a transformar-se em filmes nos quais o som possua um caráter informativo, expressivo, dramático, narrativo, argumental. Será que, apesar de o roteiro não ser literatura, seria interessante contar com ferramentas da narrativa literária para expressar a sonoridade no roteiro? Ou se trata apenas de pensar no som e descrevê-lo tão cuidadosamente quanto as imagens? A análise de diferentes fragmentos de roteiros, no Capítulo 3, nos ajudará a buscar essa resposta.

Lembremo-nos que é a partir de uma atração de feiras que os criadores de filmes começaram a refletir sobre uma escrita específica para o instrumento que lhes ofereciam. Hoje, como esta ferramenta tem sofrido impressionantes melhorias tecnológicas, a tendência é encontrar, fascinados, mais atrações, em vez de avançar em uma dialética genuína de imagem e som, correndo o risco de talvez preocupar, perturbar, surpreender o espectador, mas também com a vantagem do resultado de uma nova leitura de filmes, mais construtiva, mais gratificante. Um espetáculo onde o olho escuta e a orelha vê. (FANO, 2005, p. 3, tradução minha) 


\section{Capítulo 3: Análises da possibilidade de escrita do som em sequências de roteiros}

A análise dos manuais de roteiro, no Capítulo 1, nos permitiu concluir que, apesar de existir certo padrão convencionado para a forma que devem ter os roteiros audiovisuais e algumas sugestões quanto à indicação de diálogos e outros sons, não há regras fixas para a escrita do som. No Capítulo 2 foi possível entender que o conhecimento das possibilidades narrativas e expressivas do som é um instrumento que pode contribuir para que o roteirista leve em conta ruídos, músicas, etc. na composição do relato.

Feita esta primeira aproximação ao sentido sonoro do roteiro, analisaremos neste capítulo casos concretos de escrita do som. O objetivo é, por meio da comparação entre a sequência escrita e sequência fílmica, buscar exemplos e possibilidades de escrita do som. Não se trata de simplesmente comparar o roteiro com o filme terminado (mesmo porque o roteiro não é uma obra autônoma), mas de identificar, na escrita, os elementos sonoros que compõem narrativa e dramaticamente a mensagem cinematográfica. Em alguns momentos serão feitas algumas considerações sobre o som do filme, mas a base de análise é o roteiro pré-filmagem.

O conjunto de sequências analisadas é de roteiros brasileiros e estrangeiros, e o critério para a seleção dos filmes foi, além da presença expressiva de elementos sonoros, a variedade formal de suas escritas.

Partimos da definição de roteiro como estrutura transitória (Pier Paolo Pasolini) e da ideia de "escrita invisível" estabelecida por Jean Claude Carrière e Pascal Bonitzer, segundo a qual as indicações técnicas de enquadramento, som, etc. estão "escondidas" ou implícitas no texto do roteiro literário. Veremos que em alguns casos as indicações referentes ao som estão realmente sugeridas e subentendidas no roteiro, e que em outros são descritas de forma mais aberta, mais explícita. Contaremos também com a e as considerações de François Vanoye sobre os conceitos de roteiro-programa e roteiro-dispositivo (Alain Bergala). Tais conceitos nos ajudarão a situar o roteiro como objeto transitório entre ideia e argumento e o filme em si. Aqui tentamos entender também se o rompimento das regras da escrita convencional, ou a busca de formas dentro da forma padrão, geram uma escrita de roteiros mais sonora. 
Segundo Pasolini (1966, p. 77), o roteiro é uma "hipótese de trabalho" que contém em si a possibilidade de transformar-se em um filme.

Se não há no roteiro referência contínua à obra cinematográfica a ser feita, ele não é mais uma técnica e seu aspecto de roteiro torna-se um simples pretexto [...]. Portanto, se um autor decide adotar a "técnica" do roteiro como obra autônoma deve aceitar ao mesmo tempo a alusão a uma obra (cinematográfica) a ser feita, sem a qual a técnica que ele adotou é fictícia - e classifica-se, assim, diretamente entre as formas tradicionais de escrita literária. Se ele aceita, ao contrário, como um elemento fundamental, a estrutura de sua "obra em forma de roteiro" a alusão a uma obra visualizável "a ser feita" pode-se dizer, então, que a sua obra é ao mesmo tempo típica (ela possui características que realmente se assemelham a todos os roteiros verdadeiros e funcionais) e autônoma. Encontramos uma necessidade semelhante em todos os roteiros (de filmes de um determinado nível); ou seja, todos os roteiros são em algum momento "técnicas autônomas", cuja estrutura principal é a referência intrínseca à obra cinematográfica a ser feita. (PASOLINI, 1966, p. 77, tradução minha)

Esta ideia de que existe uma dupla natureza do roteiro escrito nos ajuda a tê-lo como instrumento de comunicação e de expressão que possui um sentido em si, mas para que se realize como obra audiovisual precisa ser transportado a outro estado, por meio de uma leitura capaz de interpretar suas possibilidades - entre elas a sonora.

\section{Segundo Pasolini,}

A principal característica do "signo" da técnica do roteiro é a seguinte: fazer alusão ao significado através de vozes diferentes, concomitantes e confluentes. Ou seja: o signo do roteiro faz alusão ao significado segundo a via normal de todas as línguas escritas e especificamente dos jargões literários, mas ao mesmo tempo, faz alusão a seu próprio significado, remetendo o destinatário a outro signo, aquele do filme a ser feito. A cada vez, nossa mente, diante de um roteiro, percorre ao mesmo tempo duas vias - uma rápida e normal e uma segunda, longa e especial - para alcançar um significado. (PASOLINI, 1966, p. 78, tradução minha)

Para que esta segunda via a que se refere Pasolini possa ser percorrida é necessária, além de uma escrita que leve em conta o caráter "incompleto" do roteiro, uma ação colaborativa por parte do leitor:

O autor de um roteiro requer de seu destinatário uma colaboração particular, que consiste em dotar o texto de um acabamento "visual" do qual ele é desprovido mas ao qual ele faz alusão. O leitor se torna cúmplice, imediatamente - diante das características técnicas do roteiro imediatamente apreendidas - da operação à qual 
ele é convidado, e sua imaginação representativa entra em uma fase criativa muito mais elevada e intensa, mecanicamente, que aquela de quando lê um romance. (PASOLINI, 1966, p. 78, tradução minha)

A este "acabamento visual" podemos acrescentar um "acabamento" sonoro como prerrogativa do leitor de roteiros, a partir de estímulos e informações que devem ser sugeridos pelo roteirista. Assim, é estabelecido um pacto entre escritor e leitor, no qual está subentendido que o roteiro é a base de uma obra a ser feita.

Pasolini afirma que o “cinema é fundado sobre um 'sistema de signos' diferente do sistema escrito-falado, ou seja, o cinema é uma outra língua", uma língua "hipotética e potencial" (PASOLINI, 1966, p. 81, tradução minha). Aqui não nos interessa entrar na questão sobre se o cinema é uma língua ou uma linguagem, mas buscar na definição proposta por Pasolini elementos que dizem respeito à escrita dos roteiros e suas limitações.

Quais são os substantivos, os verbos, as conjunções, as interjeições da língua cinematográfica? Acima de tudo, é necessário que, em conformidade a nossa lei da analogia, eles existam? Se o cinema é uma outra língua, uma língua assim desconhecida não pode ser fundada em leis que não tenham nada a ver com as leis linguísticas às quais estamos habituados? (PASOLINI, 1966, p. 81, tradução minha)

O desafio do roteirista (e do leitor de roteiros) é entender a língua cinematográfica e construir, com as únicas ferramentas que possui (as palavras: substantivos, verbos, conjunções, interjeições e também as pontuações), o roteiro. Esse documento escrito precisa, então, ser traduzido ao que Pasolini chama de outra língua para transformar-se em filme. A ideia de interpretação e tradução expressa por Pasolini supõe uma ação dinâmica, de movimento:

Assim, o signo do roteiro exprime não somente, além da forma, "uma vontade que há na forma de ser outra", mas também capta a forma em movimento : um movimento que chega livremente e de maneiras diferentes à imaginação do escritor e à imaginação colaborativa e simpatizante do leitor, imaginações que coincidem livremente e de maneiras diferentes. (PASOLINI, 1966, p. 81, tradução minha)

Para captar esta noção referente ao movimento entre a forma escrita e a forma audiovisual proposta por Pasolini, é interessante observar suas considerações a respeito do duplo caráter estrutural e de sentido da palavra dentro do roteiro:

O que é mais importante observar, é que a palavra dentro do roteiro é, ao mesmo tempo, o signo de duas estruturas diferentes e neste caso o significado que ela denota é duplo: pertence a duas línguas dotadas de estruturas diferentes. Se, ao 
formular uma definição no campo artificialmente limitado da escrita, o signo do ceno-texto se apresenta como o signo que denota uma "forma em movimento", uma "forma dotada da vontade de se transformar em outra", de formular uma definição no campo mais vasto e mais objetivo da língua, o signo do ceno-texto se apresenta como um signo que exprime significados de uma "estrutura em movimento", ou seja de uma "estrutura dotada da vontade de se transformar em outra". (PASOLINI, 1966, p. 82, tradução minha)

Pasolini define, então, a estrutura metalinguística do roteiro como um "processo particular", que "não se trata de uma evolução, de uma passagem de um estado A a um estado B, mas de um puro e simples 'dinamismo', de uma 'tensão' que se movimenta (sem portanto nem partir nem chegar) de uma estrutura estilística - a da narração - a uma outra estrutura estilística a do cinema - e, mais profundamente, de um sistema linguístico a outro" (PASOLINI, 1966, p. 82, tradução minha).

Antes da "estrutura dinâmica" de um roteiro, sua vontade de ser uma forma que se move em direção de uma outra, podemos muito bem, do exterior em termos estruturais, definir com rigor o estado A (a estrutura literária do roteiro) e o estado B (a estrutura cinematográfica). E ao mesmo tempo podemos reviver empiricamente a passagem de uma a outra, porque a estrutura do roteiro consiste precisamente nisso, nessa "passagem do estado literário ao estado cinematográfico". (PASOLINI, 1966, p. 82)

A proposta de Pasolini explicada acima pode ser complementada com a interpretação feita por Vanoye dos conceitos de roteiro-programa e roteiro dispositivo desenvolvida por Bergala. "Entre estas duas posturas - o roteiro rege o filme ou o roteiro serve ao filme, ou seja, à filmagem e à montagem -, há uma multidão de posturas intermediárias." (VANOYE, 1996, p. 19, tradução minha) Nosso objetivo, nas análises das sequências a seguir, é entender em que momento, da escrita até a finalização do filme, o som expressivo encontra espaço, e até que ponto ele pode (ou precisa) ser escrito, descrito ou sugerido já no roteiro. "Ler, em toda a simplicidade, um roteiro, significa reviver empiricamente a passagem de uma estrutura A a uma estrutura B." (PASOLINI, 1966, p. 82)

Podemos dizer que essa passagem não se trata de uma simples transformação da literatura em filme, mas de um ato de transculturação, termo

cunhado por Haroldo de Campos, na sua teoria da tradução poética. Por "transculturação" compreende-se o fenômeno do transplante de toda uma contextualização histórico-temporal e dos extratos culturais filtrados, além disso, 
pelos hábitos literários do próprio tradutor, transfigurações estas que inevitável e irrecusavelmente ficam embutidas no processo de tradução de uma língua para outra. (SANTAELLA, 2001; p. 22)

Tais transfigurações também estão embutidas no processo de transformação de uma linguagem em outra. $\mathrm{Na}$ impossibilidade de transportar ao audiovisual a totalidade do relato literário, ocorre um processo de reapropriação do relato contido no roteiro audiovisual. A ferramenta inicial para a realização desse procedimento é a palavra, primeiramente em forma de argumento e depois em forma de roteiro audiovisual. O produto final, no entanto, é uma nova tradução intersemiótica, das palavras que descrevem sons, espaços, imagens e ações à obra audiovisual em si - ressaltando que "a Tradução Intersemiótica ou 'transmutação' define-se como o tipo de tradução que 'consiste na interpretação dos signos verbais por meio de sistemas de signos não verbais', ou 'de um sistema de signos para outro'”(PLAZA, 2003, p. XI).

Ao analisar unidades dramáticas de filmes, levaremos em conta a definição de sequência segundo a qual cada uma delas é "um momento facilmente isolável da história contada por um filme: um sequenciamento de acontecimentos, em vários planos, cujo conjunto é fortemente unitário" (AUMONT; MARIE, 2003, p. 268). Foi mantida também a forma de distribuição dos diálogos, assim como o uso de maiúsculas, negritos e itálicos dos roteiros originais, pois tais elementos gráficos foram levados em conta na análise das sequências.

\subsection{Escrita invisível e o som no roteiro "padrão"}

Os roteiros que chamamos de "padrão" são aqueles que seguem a formatação sugerida pelos manuais, por editais e pela indústria: um cabeçalho que indica se a cena é uma externa ou interna, a locação e a luz (dia, noite, amanhecer, entardecer); descrição de personagens e ações em parágrafos; e diálogos centralizados. Nesses roteiros não há indicações técnicas sobre fotografia, edição ou som. Em alguns casos se escreve o som em maiúsculas ou em negrito e são usadas algumas rubricas para indicar, por exemplo, o tom dos diálogos. Além disso, neste tipo de escrita não há espaço para elaborações literárias ou poéticas: escreve-se objetivamente o que se vê e o que se ouve.

Segundo Carriere e Bonitzer, 
Se escreve geralmente por sequências, colocando um número em cada sequência, e como únicas indicações interna ou externa, dia ou noite (às vezes amanhecer ou crepúsculo), e o lugar da ação. (...) Contudo, no próprio interior dessa escrita simplificada e, além disso, pouco agradável de ler, na qual devem ser dadas todas as precisões necessárias (cenários, figurinos, movimentos dos personagens, texto, ritmo) sem indicações técnicas, subsiste uma escrita invisível, que atua sem que sejamos conscientes disso. (CARRIERE; BONITRZER, 1998, p. 42, tradução minha, itálico no original)

Assim, a mudança de parágrafo indica cortes, a descrição dos espaços e objetos sugere o tamanho do plano, o ritmo e a velocidade da escrita são indícios de como será o ritmo e a velocidade de determinada sequencia. Há informações "invisíveis" na forma como convencionamos escrever roteiros.

As sequências analisadas aqui são de três filmes cujos roteiros foram escritos no formato padrão e que possuem elementos sonoros na base de sua construção. A primeira delas é do filme Amor (2012, escrito e dirigido por Michael Haneke), a segunda São Paulo Sociedade Anônima (escrito e dirigido por Luís Sérgio Person) e a terceira do filme O céu de Suely (2006, escrito por Felipe Bragança, Maurício Zacharias e Karim Ainouz, que dirigiu o filme).

A sequência de Amor que analisamos se encontra no início do filme, e inclui as cenas 7, 8 e 9, transcritas a seguir (tradução minha):

CENA 7 - INT. QUARTO - NOITE

Georges acorda. Ele olha com espanto para seu lado, então levanta o olhar. Anne sentada ereta, com as costas apoiadas na cabeceira

\section{GEORGES}

Tem algo errado?

ANNE

Não.

Após um tempo o TOQUE de um cronômetro de cozinha nos leva à cena seguinte.

CENA 8 - INT. COZINHA - DIA 
O cronômetro de cozinha TOCA. Georges sentado em frente à janela, a uma mesa que está parcialmente posta para o café da manhã. Ele tem um telefone celular próximo à orelha e uma agenda telefônica aberta à sua frente. Anne está se levantando da mesa. Ela vai até o fogão, desliga o gás, tira o ovo da panela com uma colher e o coloca sob água fria. Como Georges, ela ainda está de roupão.

\title{
GEORGES
}

(ao telefone)

Que tal na semana que vem? Não, mas mesmo assim, seria bom fazer isso logo. Pode dar ideias bobas às pessoas. Além disso, está muito feio... Quarta? A que horas? OK... Você vai trazer a pintura, para pintar depois? Mas pelo menos uma mão... Sim, OK. Obrigado.

Ele desliga.

\section{GEORGES (CONT’D)}

(a Anne)

Dá pra contar com ele.

\author{
ANNE \\ (volta à mesa com o ovo) \\ Espero que sim. Da última vez, ele nos deixou esperando \\ por séculos, não sei se você se lembra. \\ GEORGES (ri enquanto concorda) \\ Sim, é verdade. \\ (Reage enquanto coloca o ovo em seu suporte)
}

Obrigado. Se eu chamar um profissional comum, ainda assim esperaremos dois meses.

\author{
ANNE \\ (mais para si mesma) \\ É mesmo?
}


Ela sentou-se. Olha à sua frente. Ele quebra o ovo para abri-lo, coloca sal, come.

\section{GEORGES}

Os Frodons esperaram três dias quando o banheiro deles entupiu.

Não foi exatamente agradável.

Ele come. Quer colocar mais sal, mas o saleiro está vazio.

\section{GEORGES (CONT'D)}

O saleiro está vazio.

Ele levanta o olhar por um instante, como se esperasse que ela cuidasse disso. Como ela não reage, ele percebe que sua expectativa é imprópria, fica em pé, dirige-se ao armário da cozinha e enche o saleiro.

\section{GEORGES (CONT'D)}

Não sei se ele vai nos trazer o $C D$.

Talvez ele nem venha. Em todo caso, Ele não disse nada. Eu queria comprar. Era Realmente bom e não quero esperar muito. Podemos ir à Virgin hoje à tarde e comprar.

O que você acha?

Ele volta à mesa e senta.

\section{GEORGES (CONT'D)}

Hmmm? Anne? O que foi?

Ela olha para ele e não responde.

\section{GEORGES (CONT'D)}

O que está acontecendo? Qual o problema? 
Ele balança uma mão diante do rosto dela e ri nervosamente.

\author{
GEORGES (CONT'D) \\ OOiiii!!! Cucco!!! Estou aqui!
}

Ela continua a olhar para ele sem reagir.

\title{
GEORGES (CONT'D) \\ (agora sério)
}

Anne! O que está acontecendo?

Ele espera, olha para ela. Nenhuma reação. Ele se levanta ligeiramente, inclina-se sobre a mesa para sentar-se ao lado dela. Tenta fazer com que ela se vire em sua direção.

\section{GEORGES (CONT'D)}

Anne, qual o problema?

Ele consegue fazer com que ela gire o tronco parcialmente em sua direção, mas seus olhos veem através dele.

\section{GEORGES (CONT’D)}

Anne...o que...

Ele pega seu rosto com as duas mãos e o gira para si.

\section{GEORGES (CONT'D)}

Anne...

Ela encara o vazio. Ele solta seu rosto. Então senta-se ao lado dela, por um bom tempo. SILENCIO. Finalmente ele se levanta, vai até a pia, abre a torneira, molha um pano de prato, torce-o um pouco, volta e o coloca no rosto de Anne. Espera por uma reação que não vem. Então ele levanta seu cabelo e aplica o pano na nuca. Então senta e olha para ela suplicante. 


\title{
GEORGES (CONT'D)
}

\author{
(quase chorando)
}

Anne...Querida...por favor!

Mais uma vez ambos permanecem sentados. Ao fundo, ouvimos o JORRAR da torneira que em seu pânico ele se esqueceu de desligar. Tomando uma decisão repentina, ele se levanta, cruzando rapidamente o corredor, vai para o quarto onde começa a se trocar, agitado, o que faz com que demore bastante. De repente, o JORRAR da torneira que o havia acompanhado até o quarto, para. George não percebe imediatamente, e então se detém.

\section{GEORGES (CONT’D)}

Anne?

Finalmente ele volta, meio vestido, à cozinha. Anne está sentada no mesmo lugar e olha para ele.

ANNE

O que você está fazendo?

Ela se vira para o café da manhã.

\section{ANNE (CONT'D)}

Você esqueceu a torneira aberta.

Georges a encara.

GEORGES (ao mesmo tempo aterrorizado e furioso)

Ei, o que está acontecendo? Você está completamente louca?

É para ser uma piada, ou o quê?

Ela olha para ele com espanto. 


\author{
ANNE \\ O que você disse? \\ GEORGES (sério) \\ É uma piada? É para ser uma piada?
}

ANNE

Que piada? Não entendo! Por que você está falando

assim comigo? O que deu em você?

Georges vai da porta até a mesa.

\title{
GEORGES
}

Anne! Por favor! Para com essa brincadeira.

Não é engraçado.

\author{
ANNE \\ (ficando irritada) \\ Que brincadeira, pelo amor de deus? \\ Qual é o problema?!!
}

Georges está a ponto de responder em um tom similarmente irritado, mas gradualmente começa a suspeitar de que pode estar equivocado. Ele tenta se acalmar, pega sua cadeira que ficou ao lado de Anne, senta e olha para sua mulher. Ela não sabe como reagir.

\section{GEORGES}

Qual o problema? Por que você não reagiu?

ANNE

A quê? 


\title{
GEORGES
}

A quê? A mim, a tudo.

\section{ANNE \\ Quando?}

\section{GEORGES}

Agora. Há um momento.

\author{
ANNE \\ Por favor, me diga o que está errado. \\ O que eu deveria ter feito?
}

Georges primeiro olha para o outro lado relutante, depois olha para Anne. Ele não quer acreditar que é sério.

\section{GEORGES}

Não sei o que dizer. Você realmente

não sabe o que acabou de acontecer?

ANNE

Mas O QUE aconteceu?

\section{GEORGES}

(quase relutantemente inclinando sua cabeça enquanto fala)

Você estava sentada aí, me encarando. Você não me respondeu quando te perguntei qual era o problema.

Ele pega o pano úmido da mesa.

\section{GEORGES (CONT'D)}

Eu coloquei este pano de prato no teu rosto, e você não reagiu. 
Anne olha para a toalha, depois para Georges, e balança sua cabeça, perturbada por não conseguir entender. Georges olha para ela. Ele vê as marcas úmidas na gola do roupão.

\title{
GEORGES (CONT'D)
}

Olha... tua gola ainda está úmida.

Anne acompanha seu gesto, puxa a gola e vê as marcas úmidas. Ela lentamente entende que algo está errado.

\author{
ANNE \\ Quando... Quando foi isso?
}

\section{GEORGES}

Agora, há alguns minutos.

\author{
ANNE \\ Então...?? \\ GEORGES \\ Não tem "então". Fui para o quarto me trocar. \\ Eu queria buscar ajuda.
}
ANNE
Ajuda?

\section{GEORGES}

Sim, daí você fechou a torneira.

\author{
ANNE \\ Sim. Porque você a deixou aberta.
}

\section{SILÊNCIO.}




\title{
ANNE (CONT'D)
}

Não entendo.

\section{GEORGES}

Nem eu.

PAUSA.

\author{
GEORGES (CONT'D) \\ Você não acha melhor eu ligar para o Dr. Bertier?
}

\author{
ANNE \\ Por quê? O que ele pode fazer? \\ GEORGES \\ Não sei. Te examinar. \\ ANNE \\ Estou bem. Não tem nada errado comigo.

\section{GEORGES} \\ Anne, por favor!! Isso é absurdo. \\ Não podemos fingir que não aconteceu nada. \\ ANNE \\ Mas o que ACONTECEU?
}

PAUSA.

ANNE (CONT'D)

Estou aqui. Estou tomando meu café da manhã, E você está me dizendo que aconteceram coisas que não entendo. 


\title{
GEORGES
}

Você pode me explicar como o pano de prato chegou aqui?

\author{
ANNE \\ (irritada) \\ Não, não posso!
}

\section{GEORGES}

Quem abriu a torneira?

\author{
ANNE \\ Você! \\ GEORGES \\ Você se lembra disso? \\ ANNE \\ (mais e mais desesperada, quase chorando) \\ Não, não lembro! Você quer me torturar? \\ Me deixa em paz!
}

Georges olha para ela.

\section{GEORGES}

Você não acha melhor marcar com o Dr. Bertier?

ANNE

Não!

Ela pega sua xícara de chá, como se quisesse mostrar como está bem, e bebe. Quando quer encher sua xícara, erra completamente o alvo. Ela percebe, coloca a xícara sobre a mesa e se desfaz em lágrimas. 
CENA 9 - INT. APARTAMENTO - NOITE

SILÊNCIO Vemos planos abertos do apartamento. O corredor. O quarto. A sala de estar. A sala de jantar. A cozinha. Ninguém a vista.

O primeiro ponto que podemos destacar com relação à escrita da sequência acima é o fato de alguns dos elementos sonoros importantes estarem destacados em caixa alta, inclusive as pausas e silêncios. Além disso, se formos comparar o roteiro escrito com a sequência filmada encontraremos um grau elevado de "fidelidade" ao roteiro, que ganha potência em sua tradução a imagens, sons, ações, interpretações. Mas o que mais nos interessa aqui é analisar como a sequência está ancorada em alguns elementos sonoros que fazem com que a narrativa avance, além de dotá-la de ritmo.

O primeiro som para o qual queremos chamar a atenção é o som do cronômetro da cozinha. Este som cumpre algumas funções. A primeira delas é a de caracterizar o espaço onde vivem os personagens. É um dos sons que compõem a paisagem sonora do universo verossimilhante expressado no filme, é um dos sons que nos ajudam a entrar na subjetividade dos protagonistas, a construir um ponto de "vista". Em segundo lugar, além de ser um elemento que gera uma cadência, um ritmo, ele é concebido como instrumento de transição, como recurso que será mais tarde usado na montagem do filme.

O segundo som que constrói dramaticamente a sequência é o da água saindo da torneira da cozinha. É um som do cotidiano aproveitado de tal forma que sem ele a sequência não teria sentido. O clímax da sequência está construído sobre este som. Georges abre a torneira e, dado seu estado de pressa e tensão, não a fecha. Ele muda de ambiente e o som da torneira o acompanha. Quando o som é cortado, o personagem reage. Paralelamente, foi o mesmo som que fez com que Anne reagisse, em uma ação em off. E é a partir da interrupção deste som que se inicia dramaticamente a segunda parte da sequência. O roteirista buscou, a partir do próprio espaço do cotidiano do apartamento onde vivem os personagens, um som também cotidiano que ganha expressividade ao ser usado dramaticamente. 
É importante compreender também que essa sequência contém uma ideia de ritmo marcada pelas pausas, pelos silêncios, que faz parte de uma ideia geral de composição do filme inteiro, e é um elemento que dá unidade e forma à obra como um todo. A opção do autor é, após um momento de grande intensidade dramática e de um crescendo de diálogos, construir uma cena "silenciosa", a cena nove, que fecha a unidade dramática da sequência ainda contando com os sons do cotidiano do apartamento dos protagonistas.

Nessa sequência, portanto, o som é um elemento estrutural e argumental, que só pode ter essa função pois foi levado em conta desde o roteiro e registrado em palavras. Existe uma economia de palavras, poucas descrições, quase nenhum adjetivo. Mas o fundamental para a tradução ao relato audiovisual está dado, e permite que ele se desenvolva.

Já no caso de São Paulo Sociedade Anônima podemos notar, logo na sequência inicial do filme, a opção do roteirista de jogar com o espectador ao "sonegar" a informação sonora.

\section{1) APARTAMENTO DE CARLOS - EXT. - INT. DIA}

Do terraço, através do janelão de vidro, sem nenhum som, vemos no interior do living do apartamento, ao fundo, Carlos e Luciana que discutem junto da mesa preparada para o café da manhã. Depois de um momento, Luciana segura o braço de Carlos com força, tentando impedi-lo de fazer derramar o bule de café sobre a mesa. Num gesto rápido, Carlos a empurra com violência e Luciana cai no chão, lágrimas nos olhos, desesperada. Ao fundo, Carlos desaparece. Sobre esse plano entra o primeiro título de apresentação e a música.

$$
* * *
$$

"Na montagem final, percebemos que o nenhum som proposto por Person foi trocado por vozes distantes, quase inaudíveis - o que, segundo Renato Magalhães Gouvea, levava muitos espectadores a reclamar do baixo volume de áudio no início da projeção.” (MORAES, 2010, p. 194) Apesar de o filme não seguir exatamente o que o roteiro diz , não se escuta o diálogo com clareza e os movimentos e ações dos atores apenas sugerem ruídos (palavras e derrubada de louças, por exemplo). Só escutamos a última fala de Luciana: "Covarde". A intenção de que não se entenda o que os atores dizem no roteiro foi mantida, apesar de ter sido traduzida em imagens 
e sons além daqueles previstos em um primeiro momento. Esta forma de tratamento sonoro já dá os primeiros sinais de que se trata de uma narrativa não clássica: o som não está sempre em função dos personagens. Ao longo do filme, nem sempre o que os personagens estão dizendo é importante, nem sempre os diálogos estão em primeiro plano, revelando um distanciamento de certo "vococentrismo".

No final do filme, em seu clímax, há uma reconstrução dessa primeira sequência, agora com o som da discussão de Carlos e Luciana, em que ele diz "Luciana, vou dar o fora". A música vai se intensificando (as indicações da presença de música são dadas desde o roteiro). Carlos diz: "Sei que devo deixar tudo e recomeçar, ou acabar de uma vez por todas." Quebra objetos da sala. Luciana grita a primeira fala do filme: "Covarde". Com a cidade ao fundo, a música acelera. Existe, entre a primeira sequência e a sequência 38, que é uma repetição da sequência 1, uma diferença fundamental, e essa diferença é proporcionada pelo som e pela quantidade e qualidade da informação sonora transmitida ao espectador.

Apesar de a versão final do filme não seguir tão fielmente o roteiro como no caso de Amor, é possível identificar que ambos filmes, recorrendo a uma escrita padrão de roteiro audiovisual, levaram em conta os recursos sonoros desde a etapa do roteiro.

Já o início do filme $O$ Céu de Suely também aponta para informações sonoras interessantes, escritas em uma forma "padrão". Escolhemos a primeira sequência do roteiro (que não é a primeira sequência do filme, pois este último conta com um prólogo musical que se inicia com uma narração em off da protagonista).

\section{1 - INT. SÃO PAULO/ ÔNIBUS - NOITE}

Plano aéreo de São Paulo. Uma megalópole sem fim, um mar de luzes a perder de vista. Motor ligado. Choro baixinho de criança. Trânsito intenso. A janela de um ônibus no escuro. Lá fora as luzes coloridas de uma cidade grande, buzinaço e rugidos de motor. O ônibus parado, engarrafamento. Ao longe, através do vidro, imensas antenas de TV e uma cidade gigantesca, a terceira maior do planeta. No breu, vemos Suely - uma jovem de 20 anos - com a cabeça encostada no vidro da janela, olhos bem abertos, vestindo um casaco, cachecol de lã e sentada bem ao fundo do ônibus. Suely tem um bebê chorando em seu colo - Italo Júnior - e respira perto 
da janela, olhar atento. Sua respiração deixa o vidro embaçado e ela limpa com a palma da mão. O bebê continua chorando de leve. Buzinas lá fora. Os sons do trânsito continuam invadindo o ônibus. Suely aproxima o rosto do menino - sua boca quase toca a boca dele... bem de perto, no breu. O menino chora de leve.

\author{
SUELY \\ Ssshhh... Ssshh... Ssshhh...
}

2 - INT. ÔNIBUS/ESTRADA -DIA

Sol amarelo na janela. Uma estrada sinuosa banhada por uma luz doce e dourada. Uma paisagem de colinas, diferentes tons de verde. Poucas habitações. O ônibus segue em grande velocidade. Suely está dormindo, o braço escondendo seu rosto da luz intensa. Agora é Suely que se reflete na janela. Italo Júnior dorme na poltrona a seu lado, deitado entre uma mochila e uma bolsa de bebê. 12 Silêncio. Apenas o motor do ônibus e um diálogo abafado de aparelhos de TV.

3 - INT. ÔNIBUS / ESTRADA SERTÃO - NOITE

Escuridão. O ônibus segue - lá fora, uma estrada vazia e escura. Suely está acordada olhando para fora, Italo Júnior dormindo a seu lado. Alguns poucos feixes de luz invadem o ônibus.

\title{
CORTA PARA:
}

Agora, Suely está de pé, na parte de trás do ônibus, com a porta do banheiro aberta e a mão direita esticada para dentro - ansiedade. Suely observa Italo Júnior dormindo sozinho na poltrona, coberto por seu casaco. Estica a cabeça para dentro do banheiro - vemos fumaça. Suely está fumando. Solta a fumaça para dentro do banheiro e volta a olhar seu menino. Fica assim, dividida entre a fumaça, que começa a encher o cubículo iluminado do banheiro, e o corredor escuro onde seu filho dorme. O ônibus balança na estrada esburacada. Suely se segura. Italo Júnior quieto. Suely entra no banheiro. Apaga o cigarro na minipia. Puxa a porta com força. Escuridão completa.

4 - Ext. Estrada / ônibus - dia 
Um jorro de luz. Sol a pino. Sol branco. O ônibus segue em alta velocidade por uma estrada esburacada, no meio de uma grande planície. Quase nenhum outro veículo.

Suely no ônibus, vento na janela - enfado e tédio. O rosto suado e a pele oleosa. Suely leva Italo Júnior bem apertado junto ao peito. Mamadeira na mão. Hipnotizada pela luz. A seu lado, a mochila e a bolsa de bebê, semiabertas. Paisagem árida, plana - um quase deserto. Vegetação de arbustos ressecados, e um céu azul, muito azul, com nuvens que flutuam aqui e acolá. Poderíamos estar na lua num dia de sol e céu claro. Calor.

\section{5 - EXT. POSTO BARREIRAS. DIA}

Sol forte. O ônibus parado em um pátio amplo e vazio de um posto de gasolina à beira da estrada - circundada por uma ampla planície. Suely está com Italo Júnior no colo e mochila nas costas. Um RAPAZ abre o porta-malas do ônibus e puxa uma mala de náilon azul, imensa. Atrás dela, descem 3 PASSAGEIROS.

\section{CORTA PARA:}

Suely está sentada no degrau de uma pequena escadaria na frente do posto. Menino no colo, mochila, mala de náilon azul a seus pés. Suely se abana e observa a estrada. Nada. Só o sol e o asfalto.

\section{CORTA PARA:}

Céu azul. Ruído de moto ao longe (off). Suely continua sentada, olhos quase fechando, Italo Júnior no colo.

Uma MOTOCICLETA vem aproximando-se, dirigida orgulhosamente por uma mulher de capacete, IVONETE. Ela pisa no descanso e salta da moto, aproximando-se de Suely, sem tirar o capacete. Ela chega até Suely, devagar. Suely começa a abrir os olhos. Ivonete assobia: fiu-fiu. Suely abre os olhos devagar - olhos brilhando - fixam em Ivonete, como que vendo uma miragem.

\section{SUELY}

Saudade. 


\section{IVONETE}

Disse que vinha?... Tô aqui.

\section{SUELY}

Tô vendo... Tou podre, tia.

Suely se levanta ainda zonza de sono. Ivonete pega Italo Júnior no colo e olha para ele com carinho.

\section{IVONETE}

Nem acredito no que estou vendo... Italo. Coisa mais linda do mundo.

\section{SUELY}

Italo Júnior Ferreira Tavares. Tem os olhos do pai.

Suely ajeita a mochila nas costas, olha a moto da tia.

\section{SUELY}

Comprou uma moto, foi?

\section{IVONETE}

Emprestada. Pra botar banca pra sobrinha.

Ivonete entrega o menino a Suely e pega a mala de náilon azul do chão, está pesada.

IVONETE

Vamo?

SUELY

Vamo... Moto linda mesmo. 
Ivonete arruma a mala na moto. Suely espera, observando de perto - observa a tia, com carinho. Ivonete tenta subir com dificuldade - a mala é grande. Ivonete ri.

\section{IVONETE}

Linda, mas é o seguinte: vamo ter que fazer duas viagem...

\section{CORTA PARA:}

Ronco de moto ao longe. Suely de pé, Italo Júnior no colo, à beira da estrada. Ivonete parte de moto, mala azul amarrada atrás, acena animada para a sobrinha. Some na estrada.

O início da sequência enfatiza os sons da megalópole: buzinas e buzinaço, motores, escutados do ponto de vista da personagem que está dentro do ônibus (Suely, que passou a se chamar Hermila no filme), que escuta também a própria respiração e choro de um bebê. A forma como a sequência está escrita descreve os sons do ambiente externo e do ambiente interno, preocupada em enfatizar as características audiovisuais da cidade, que logo serão contrastadas com as do interior. $\mathrm{O}$ som aqui não transforma argumentalmente o relato, mas está presente de uma forma expressiva, que não conta só o que estamos vendo. Ítalo Júnior (personagem Mateuzinho no filme), por exemplo, é apresentado primeiro pelo choro, e só depois vemos que é o filho de Suely.

Outro som importante para o relato, marcado inclusive com caixa alta, é o som da motocicleta. Este som estará presente ao longo de todo o filme. Bem no começo, é mais um som misturado com outros da cidade. Depois, ele aparece em um espaço mais vazio, ganhando protagonismo e contrastando com o ambiente da caatinga. O som da moto vai "enchendo" aos poucos o espaço sonoro e introduz a apresentação da personagem da tia de Suely, Ivonete. Suely (e o espectador) primeiro escuta sua aproximação, para depois vê-la. Tudo o que diz respeito ao som da motocicleta, sua aproximação e seu distanciamento, está relacionado, neste primeiro momento, a Ivonete. Mas ao longo do filme, esse som que foi apresentado no início, será recorrente e irá relacionar-se a outro personagem importante, João. 
- Além da descrição do espaço sonoro e dos objetos, os diálogos são escritos de forma a entrarmos no mundo da personagem. Eles são escritos de uma forma fonética que indica a sonoridade das falas, em uma representação escrita dos sotaques. É possível entender também, a partir do roteiro, uma intenção de levar o espectador ao espaço sonoro de Suely e a seu ponto de "vista" sobre o mundo que a rodeia. É uma decisão de proposta estética que relaciona espectador e personagem por meio dos sentidos da personagem.

\subsection{O som no roteiro "técnico"}

Os manuais de roteiros analisados no Capítulo 1são praticamente unânimes ao afirmar que os roteiros não devem conter indicações técnicas, como movimentos de câmera, enquadramento, etc. Tais indicações pertencem ao mundo do roteiro técnico: no Capítulo 2, observamos que Saitta faz uma distinção prática entre roteiro literário e roteiro técnico, afirmando que o primeiro contém o que queremos dizer e o segundo incluiria o como, a forma. (SAITTA, 2002, p. 38). Existe uma forma de escrever roteiros que se distancia um pouco desse padrão, ao incluir elementos técnicos nas descrições das sequências. Aqui analisaremos duas sequências de filmes que usam o som como elemento narrativo na construção do relato: Barton Fink (1991, escrito e dirigido Joel Coen e Ethan Coen) e O bandido da luz vermelha (1968, escrito e dirigido por Rogério Sganzerla).

O roteiro do filme Barton Fink não está dividido em cenas numeradas, mas a partir dos enquadramentos e movimentos de câmera que levam aos espaços, ou do ponto de vista do personagem Barton. A sequência que analisamos, transcrita e traduzida abaixo, está na primeira parte do filme (do minuto 18 ao minuto 22).

\section{PLANO SEQUÊNCIA}

Estamos no corredor do sexto andar do Earle, tarde da noite. Um par de sapatos em frente a cada porta. Levemente, de um dos quartos, podemos ouvir o clack. clack. clack. de uma máquina de escrever. Fica mais forte conforme nos aproximamos. 
Tão perto da máquina que só vemos cada letra ser batida, sem contexto. Uma a uma as letras fazem clack escrevendo: a-u-d-í-v-e-l. Após uma batida curta, um ponto final é tocado.

\section{BARTON}

Com os cotovelos sobre sua escrivaninha, ele olha para o que acaba de escrever. Ele roda o papel para cima algumas linhas, olha mais um pouco.

\section{A PÁGINA}

Diz: FADE IN Um prédio de apartamentos em Lower East Side, Manhattan. O tráfego do começo da manhã é audível.

\section{BARTON}

Após uma batida ele rola a página de novo para o lugar.

\section{PRIMEIRÍSSIMO PRIMEIRO PLANO}

A área de onde saem as letras. Está alinhada com o último ponto final, que é coberto por uma vírgula. As palavras "como é" são datilografadas e cortamos de volta para - BARTON enquanto ele continua a datilografar. Ele para após vários caracteres e olha. Silêncio. Quebrando o silêncio, uma risada abafada do quarto adjacente. Uma risada de homem. É cansada, solitária, desconsolada. Barton olha acima, para a parede diretamente à sua frente.

\section{SEU PV}

A imagem da garota na praia. BARTON encarando, enquanto a risada cansada continua. Barton olha de novo para sua máquina de escrever como se fosse continuar o trabalho, mas o som é insistente demais para ser ignorado.

\section{PLANO ABERTO}

O quarto, Barton sentado à sua escrivaninha, encarando a parede. A risada. Barton empurra sua cadeira para trás, fica em pé, vai até a porta, a abre e olha para fora.

\section{SEU PV}


O corredor vazio, um par de sapatos diante de cada porta. No final do corredor uma lâmpada vermelha escura acesa sobre a porta para as escadas, pontuando o brilho amarelo doentio da linha de arandelas. A risada, apesar de ainda débil, é mais ressonante no corredor vazio. Talvez sua qualidade tenha mudado, ou talvez por ser tão insistente, a risada agora poderia ser tomada por choro. Barton pausa, tentando interpretar o som. Ele lentamente se retira para seu quarto.

\section{SEU QUARTO}

Barton olha para sua máquina de escrever para datilografar. A risada/choro continua. Ele anda até sua cama, senta e pega o telefone.

\section{BARTON}

Alô. . . Chet? É Barton Fink do 605. Sim, tem uh, tem alguém no quatro vizinho ao meu, 604, e ele está uh . . Ele está uh . . . fazendo muito . . . barulho. Após uma batida: . . Obrigado.

Ele coloca o telefone no gancho. A risada continua por alguns momentos, então abruptamente para com o som abafado do telefone tocando no quarto ao lado. Barton olha para a parede. O som abafado de um homem falando. O som do telefone sendo colocado no gancho.Passos abafados no quarto ao lado. O som da porta vizinha abrindo e fechando. Passos aproximando-se do corredor. Uma batida dura, presente, na porta de Barton. Barton hesita por um momento, então se levanta e vai até a porta.

Este é um caso em que o roteiro também se parece bastante à obra finalizada. A primeira forma da escrita que nos chama a atenção, nesta sequência que mistura informações técnicas, ações e pontos de vista, é a descrição da perspectiva sonora (aproximamo-nos do quarto e o som da máquina de escrever vai aumentando) e a opção pelo uso de uma onomatopeia (clack, clack, clack) . Em seguida, o "clack" é novamente usado, e os roteiristas escrevem o que escreve o personagem, separando as letras da palavra "audível" com hífens. A hifenização proporciona informação sonora, pois ajuda a expressar que cada letra é datilografada após um intervalo e com determinada intensidade. Além disso, trata-se de uma palavra que se relaciona com o mundo sonoro. Logo depois, o roteiro descreve uma "batida curta", iniciando uma adjetivação dos sons que estará presente em toda a sequência. 
Toda a descrição dos sons provocados por ações de Barton na máquina de escrever: batida, rolamento da página, clack das teclas, etc. formam uma base de ruídos que mais tarde são enfatizados pela edição de som, compondo o ambiente sonoro do filme, que está ancorado principalmente no trabalho com ruídos, provenientes de espaços e objetos. Há pouca música : “os Coens imaginaram o filme como uma obra mais conduzida pelo som que pela música. O roteiro, na verdade, contém várias cenas com pouco ou nenhum diálogo e uma preponderância de efeitos sonoros que têm impacto direto no enredo.” (BARNES, 2007, p. 4, tradução minha)

Os silêncios (e quebras de silêncios) também são escritos. Depois, as ações de Barton são motivadas pela risada proveniente do quarto vizinho. O roteiro faz uso de uma série de adjetivos para descrever essa risada: abafada, de homem, cansada, solitária, desconsolada, débil, insistente. "O som é insistente demais para ser ignorado" e é o que faz Barton reagir e mudar o curso de sua ação (escrever) nessa sequência. É o som da risada que move dramaticamente a cena: Barton vai investigar sua origem, a risada muda seu caráter quando ele vai até o corredor: "agora poderia ser tomada por choro", o que faz com que o personagem pause, "tentando interpretar o som".

A segunda etapa de apresentação do personagem vizinho, após sua risada, é descrita em uma série de sons abafados: do telefone, da fala, dos passos, em uma sequência ouvida, vista e sentida desde a perspectiva de Barton, que culmina no som final antes da apresentação física do personagem Charlie Meadows: uma "batida dura, presente".

A escrita do diálogo também incorpora os titubeios de Barton, ajudando a caracterizar a fala do personagem, por meio de reticências e "uhs". Pudemos identificar essa busca pela sonoridade da fala em $O$ céu de Suely. Isso nem sempre acontece. É frequente, na escrita de diálogos, que os mesmos sejam redatados seguindo a lógica da linguagem escrita, e não da linguagem falada. Depois, na etapa de ensaios e filmagens, os atores realizam uma tradução do texto escrito ao texto falado. Esta tradução pode continuar na etapa de dublagem, se for o caso.

O que mais chama a atenção na escrita do roteiro dos Coen não é o fato de ele conter uma série de indicações técnicas, mas a quantidade de descrições e adjetivações dos sons do espaço, dos objetos e dos personagens, que caracterizam uma tomada de liberdade contundente com relação à escrita padrão, que pede mais objetividade. 
Por último, é interessante observar esse roteiro como base para o trabalho da equipe de som do filme, como observa o professor e editor de som Randall Barnes:

É principalmente com a ajuda de elementos auditivos (efeitos sonoros, diálogo e música) que os irmãos Coen conseguem cultivar uma atmosfera de inquietação que não só enfatiza o estado de espírito de Barton, mas também complementa as ambiguidades do filme. Ao costurar os esparsos ingredientes sônicos de uma forma sutilmente ondulante, o supervisor da edição de som Skip Lievsay e o compositor Carter Burwell trazem uma coesão bem definida à trilha sonora. Consequentemente, os cenários sonoros de Barton Fink transcendem o papel tradicional de meramente reforçar os visuais, o que, por sua vez, encorajam níveis mais profundos de significado. (BARNES, 2007, p. 2, tradução minha)

Barnes revela ainda que "o compositor e o supervisor de edição de som receberam cópias do roteiro para usar como base das discussões preliminares na pré-produção" (BARNES, 2007, p. 2, tradução minha). Como perguntamos no Capítulo 2, seria o caso de trazer sempre o projetista de som para a criação do roteiro, ou para os momentos de leitura do mesmo? É difícil encontrar uma resposta única para essa pergunta, mas no caso deste filme a resposta é sim, e resulta em um trabalho conjunto de direção, roteiro e som.

Foi a abordagem unificada de Lievsay e Burwell à trilha sonora relacionada ao roteiro dos Coens que deu ao mundo sonoro de Barton Fink uma estrutura integrada. Seus esforços não só complementaram um ao outro, mas também trabalharam em harmonia com a construção geral do filme. Como resultado, esse modo de produção ajuda não só a demonstrar um maior potencial da trilha sonora, mas também afirma os benefícios de uma colaboração mais próximas entre os responsáveis por sua construção. (BARNES, 2007, p. 21, tradução minha)

Assim, apesar de cada filme pedir um processo de criação diferente de acordo com suas necessidades estéticas, a participação de projetistas de som na etapa de roteiro pode contribuir para que se dê atenção aos aspectos sonoros das imagens, da trama, do espaço, dos personagens, etc. Barnes, em sua análise de Barton Fink, observa que algumas (boa parte) das informações sonoras estão previstas no roteiro, outras não. É o caso do som proveniente no quadro pendurado no quarto de Barton Fink, mencionado na sequência que analisamos:

Barton consegue encontrar algum tipo de consolo no hotel na forma de uma imagem que está pendurada na parede de seu quarto. É de uma praia onde uma mulher jovem, de costas, observa o mar. Sempre que Barton a espia a trilha sonora emite uma sequência tranquila de ondas e gaivotas (roteirizada) acompanhada de uma nota alta progressivamente crescente (não roteirizada). (BARNES, 2007, p. 10) 
Assim, mesmo em se tratando de um roteiro em que o som é um elemento argumental, previsto, contemplado e desenvolvido desde o roteiro, as outras etapas de produção e pósprodução são momentos em que surgem novas ideias para a expressão sonora, que é mais ou menos eficaz segundo a clareza que os criadores têm a respeito do tipo de estética audiovisual que querem compor.

Já o roteiro de $O$ Bandido da Luz Vermelha, de 1967, publicado pela coleção Aplauso em 2008, é uma mistura entre roteiro literário e roteiro técnico, com muitas indicações de enquadramentos e movimentos de câmera. A primeira sequência analisada inclui as cenas 40, 41, 42,43 e 44.

40 - INT; NOITE; QUARTO QUALQUER

PA (MF) Plano fixo. Pans didáticas: Mulher deitada, com roupas rasgadas, no chão... BANDIDO passa ao fundo, fugindo com televisor portátil, relógio, uma calcinha e um presunto. Sai por uma porta. PAN retorna até ela.

\section{1 - EXT; DIA; RUA TRAVELLING}

PA (FI) Câmera segue uma garota elegante. CLOSES do seu corpo. Parado numa esquina, o BANDIDO a observa, controlando o ambiente, chupando drops. Observa uma caderneta de endereços de mulheres (DETALHE). Risca e seleciona endereços. Anota o número do prédio em que entra a garota.

\section{2 - INT; NOITE; APARTAMENTO}

CLOSE, TRAVELLING na mão: Garota caminha pelo apartamento desligando TV e escolhendo discos. Bandido OFF - Campainha. Ela atende. BANDIDO entra e a ameaça com navalha. Tempo. Ela não oferece qualquer resistência. Plano geral. O marginal aproxima-se. Pressionada, despe-se lentamente. BANDIDO larga a navalha.

43 - INT; NOITE; APARTAMENTO: COZINHA

PP PANS soltas pelo décor: BANDIDO abrindo geladeira e tomando algo. Mulher entra no quadro. Abraça-a.

44 - INT; NOITE; APARTAMENTO QUALQUER 
PA (MF) PANS soltas: BANDIDO Entra em quarto. Alguém dorme. BANDIDO empurra cabeça da vítima para reconhecê-la: um rapaz cabeludo que o olha espantado. BANDIDO recusa-o, saindo rapidamente do quadro.

Texto 8 - As autoridades só pedem uma coisa: Pelo amor de Deus não façam dele um herói. Principalmente o rádio e a TV que espalham a versão do ladrão bondoso e cavalheiro que roubava dos ricos para dar esmolas aos pobres, principalmente às criancinhas pobres, a quem compraria doces, sorvetes e outras guloseimas; era uma versão mentirosa porque ele não passava de um ladrão grosso chato faroleiro, com um imenso repertório de palavrões.

Nesta sequência em que o bandido persegue a uma Moça, dá-se a entender que ainda estamos ao som da música Vereda Tropical (proposta na sequência anterior) e de alguns sons pontuais (off campainha, por exemplo). A forma como o tex to do roteiro está escrito, combinando valores de plano, cortes e descrição de ações sugere uma ideia de ritmo ao relato. Ainda que a tradução para o filme não siga exatamente o que está escrito, valores da "escrita invisível" como ritmo, tom, velocidade são passados ao relato audiovisual. Vale comentar que na mise-en-scène surgem outros sons importantes para a construção da narrativa do filme e a caracterização sonora do protagonista, como o assobio do bandido, por exemplo, que nunca é mencionado no roteiro. Aqui também está previsto no roteiro novo texto em voz over. No filme, esses textos são divididos entre a voz feminina e a masculina. No roteiro, apesar de fazer-se menção a estes dois narradores na primeira cena, essas vozes over aparecem apenas como "TEXTO:".

A segunda sequência analisada envolve as cenas 91, 92, 93, 94, 95, 96 e 97.

91 - INT; DIA; STUDIO TV

\section{OFF}

\section{SPEAKER}

Quantos tiros já levou excelência?

JB

Uns cinco mil mais ou menos, porém fui atingido apenas por 37.

PA (MF) Ambiente de estúdio: cinegrafista com câmera na mão e outro anônimo. TRAVELING aproxima-se de JB e Speaker. Câmeras o cercam. Agitação no estúdio. 


\section{JB (CONT.)}

... Nunca fiquei mais de uma semana na cama porque tenho corpo fechado senhores espectadores. não morro assim tão fácil por obra de Cosme e Damião, os meus santos protetores...

\section{SPEAKER}

Que acha do colete Taterssal à prova de bala?

JB

Prefiro o meu, jovem. Uso há trinta anos.

SPEAKER

Já pensou em ser diplomata?

JB

Nunca tive inclinações para matemática, diplomata e gramático.

SPEAKER

Mas dizem que o Ministro...

JB

(INTERROMPENDO-O)

Ministro não; Secretário...

\section{SPEAKER}

Exatamente. dizem que o Secretário é um mestre no piano, um novo Mozart excelência?

JB

Compus chorinhos, valsinhas, coisas à toa.

\section{SPEAKER}

Já matou alguém excelência?

JB

Não, eu não: quem mata é Deus...

Texto 16 - JB, o candidato da Boca à Presidência da República.

JB toma água mineral. Câmeras avançam. Ambiente do estúdio.

JB

Sou praticamente vitorioso. Foi preciso senhores espectadores foi preciso aparecer um místico de terno branco o lenço encarnado no pescoço para dar ao povo uma luz de esperança. O programa 
do meu governo é eu mesmo! Eu! Vou abrir as portas das prisões. Comprar vassouras piaçavas, creolina e principalmente isto aqui (exibe uma bomba de Detefon).

Vai ser a desinfecção dos cofres públicos. Ratoeira para os ratos oficiais. Meu governo vai ser a campanha do Detefon filhos...

Corte

\section{SPEAKER \\ (LENDO LIVRO)}

Ninguém deve ignorar que comente ao Estado compete o uso da violência organizada, educada na base da hierarquia e da disciplina, representada pela Justiça, Forças Armadas e a Polícia. Uma forma superior de organização destinada à manutenção do Estado do Direito, quer dizer, o império da lei - como bem assinala Tavares Holanda.

JB

(INTERROMPENDO-O BRUSCAMENTE)

E tem mais uma coisa jovem: já vou avisando: se houver roubo nas eleições prometo que o assunto será resolvido a bala, pelas armas senhores espectadores...

\section{SPEAKER}

Mas a candidatura sairá quando, pelo seu partido?

$\mathrm{JB}$

Exatamente. Pelo glorioso Partido Trabalhista Cristão. Sairá quando chegar a hora. Entre a pressa e a diligência, fico com a diligência.

\section{SPEAKER}

Mas excelência não estamos em cima das eleições?

JB

Não há motivo de pressa porque o Brasil em vez de andar, carangueja.

SPEAKER

A que deve tanta sorte nos atentados?

JB

A Divina Providência sem dúvida... Especialmente o Espírito Santo que sempre guiou os meus passos e também à fanática confiança em mim mesmo... Consigo até acertar num cigarro a vinte metros... Mas depende... Smith and Weston 38? 


\author{
SPEAKER \\ É sua predileta?
}

JB

Desde mocinho.

SPEAKER

Com essa acerta?

JB

Não erro.

SPEAKER

E a morte do Delegado Pernambucano, seu velho inimigo?

JB

(INTERROMPENDO)

Só se abrirem um novo inquérito. Fui absolvido por unanimidade. 5 a 0 , senhores espectadores.

\title{
SPEAKER
}

Mas porque o chamam de pistoleiro?

JB

Porque não podem me chamar de ladrão. Ninguém pode me chamar de ladrão. Tudo, menos ladrão. Na Presidência, vou acabar com a ladroeira nacional, com os ladrões grandes e os ladrões pequenos. Tenho toda a ficha do B desse BANDIDO da Luz Vermelha...

\section{SPEAKER}

Mas a Excelência sabe de alguma coisa?

JB

Tudo, sei de tudo!

92 - INT; DIA; APARTAMENTO

CLOSE de BANDIDO que vê televisão. Entrevista no vídeo (DETALHE) PP: abre vidro com preparado químico, destinado a tingir o cabelo.

SPEAKER OFF

Com que dinheiro fundou A Voz do Povo?

JB OFF

(CORRIGINDO-O) 
Vox Populi! A Vox Populi é um jornal que eu fundei com o dinheiro de amigos para ajudar os mais fracos. Uma coisa posso dizer de boca cheia: nunca pratiquei o crime da omissão! Não, essa não! De trinta para cá sempre estive em todos os movimentos revolucionários, e sempre evitando derramamento de sangue. Fui preso em 37 porque não quis a ditadura. Lott me perseguiu porque

socorri Carlos Luz. Nunca fiquei protegido sob as marquises na hora da luta. Sempre estive lá, no meio dos vendavais. Eu, que nunca roubei, nunca explorei o jogo nem o lenocínio e nunca fui governo. Eles sim. Até que me provem o contrário, o Sr. Amaral Batista é o rei da corrupção paulistana. Quero saber onde eles puseram o dinheiros dos caças arrecadados do povo durante a II Guerra para comprar os caças submarinos. Tenho todos os documentos aqui (exibe pastinha). Senhoras e senhores: estou escrevendo um livro que vai ser a bomba atômica do momento, a verdadeira história do Brasil de 1800 para cá...

\section{3-INT; DIA; APARTAMENTO}

DETALHE: Mão do BANDIDO escreve nas bordas de cédula monetária: 1967 Domingo sem sol. Santos 1 Corinthians 3

CLOSE DO BANDIDO, já de cabelo loiro.

PG: observa o televisor. Enfastio. Muda estações. Outros programas. Vai até janela e contempla a boca.

Plongée de PIVETE na rua; ela conversa com LUCHO GATICA.

94 - EXT; DIA; BOCA

PP PLONGEE; PIVETE dá dinheiro a LUCHO GATICA que se afasta rapidamente. TRAVELING semi-inclinado o acompanha. Alemão entra no quadro, sempre silencioso o circunspeto. PIVETE corre novamente até LUCHO, beija-o, dizendo:

\section{PIVETE}

Você é Bárbaro... Bárbaro LUCHO... LUCHO Mais ou menos... Mais ou menos.

Ela se afasta; PG: um automóvel estaciona, cujo chofer conversa com ela, discutindo preços. Ainda PG: um outro freguês. Entram em hotel suspeito. O ambiente geral de prostituição. Alemão e LUCHO falam sobre negócios. Diálogos semi-inteligíveis. LUCHO, com nota de dez dólares na mão, exclama:

\section{LUCHO}

São os dólares. aí eu falei pra ela... Como é que é minha filha? Meu negócio são os dólares... Daqui para frente só aceito dólares. 
TRAV câmera semi-inclinada dos dois homens que entram no Hotel Continental.

95 - INT; DIA; APARTAMENTO

PP BANDIDO ligando novamente a Televisão: DETALHE: vídeo

\section{SPEAKER}

Mas dizem que a excelência não preenche os requisitos para governar o Estado, muito menos o país.

\section{JB}

Olha: eu posso destruir muita gente bacana, é só eu querer (exibe sua pasta). As provas, aqui estão as provas! Os políticos e os criminosos grandes desse país, quem joga na direita, na meia esquerda do Brasil. 362 nomes. São 342 nomes conseguidos no Ministério, diretamente do cofre do Ministro...

\section{SPEAKER}

Denunciam vossa excelência... Por explorar o lenocínio do estado?

JB

É porque são todos comunistas! Todos eles! Olha: 300 milhões

(faz gesto de número com as mãos nervosas).

Passaram a mão em 300 milhões e ninguém disse nada. Apropriação indébita. 17 são comunistas fichados, levantaram 80 milhões do fundo sindical para acabar com a honrosa campanha anticomunista brasileira, a única coisa séria desse país. São agitadores perversos e perigosos. Vou denunciar os verdadeiros professores do gatilho, eles, o Senador que embolsou meio bilhão só numa manobra cambial (exibe enorme mapa) aqui estão os grupos que exploram...

96 - INT; DIA; STUDIO TV

\section{SPEAKER}

E as bombas Secretário?

JN De fonte segura, sei que um grupo - não sou eu quem diz, resolveu liquidar eu, o Lacerda, o Tenório e outros. Mas cavam a própria sepultura...

\section{SPEAKER}

Então há mesmo um complô?

JB (sorri) 


\section{SPEAKER}

E os nomes Ministro, aliás, Secretário?

JB

Meia dúzia de apaixonados. Vou soltar a bomba atômica do momento no dia do lançamento da candidatura. Na Sede do Esporte Clube Epopeia farei a nação despertar para a realidade. Precisamos mais dinheiro para acabar com a chaga comunista porque a lei aqui é como teia de aranha: só serve para prender moscas! Uma lâmpada, uma simples lâmpada, por exemplo: em qualquer lugar do mundo é feita para durar no mínimo vinte anos. Aqui dura 15 dias. Ora, isso pesa, pesa na economia do povo. Um roubo! Um crime! Defendo medidas drásticas contra o capital estrangeiro, apoio o intervencionismo econômico, o monopólio estatal do petróleo, e a exploração da Amazônia - ah a grande Amazônia, quando é que vai despertar? (delirando) a nacionalização dos depósitos - bancários, da indústria farmacêutica, das indústrias siderúrgicas e dos serviços públicos urbanos, é a defesa da reforma agrária. total... quero servir o Brasil até o desespero, sem as distorções que se procura fazer aos que servem com devoção à lei, ao povo e à pátria...

Música cresce.

SPEAKER

Acabaram de ouvir senhores espectadores mais um programa A Voz dos Líderes...

97 - INT; DIA; APARTAMENTO

CÂMERA NA MÃO; CLOSE; BANDIDO batendo na PIVETE, exclamando:

BANDIDO

Com o meu tutu, vagabunda? Quem é esse cara? ... Um gigolô, pra cima de mim? Pensa que sou trouxa?

Ela cai no chão.

\section{BANDIDO OFF}

Levanta, pega teus trapos e cai fora!

Ela continua deitada no chão enquanto BANDIDO sai do quarto. Ela acompanha-o pelo apartamento. PIVETE apanha uma navalha e, num ímpeto violento, destrói objetos do apartamento. Rasga roupa do marginal; abre guarda-roupas e rasga vestes. Debaixo da cama, encontra a mala de BANDIDO Está trancada. Com dificuldade, arromba a fechadura. 
TRAV P/ FRENTE DETALHE: Mala repleta de objetos estranhos: jornais, placas de automóvel, santinhos, injeções, batina, retratos de família, banana de dinamite, lenços, máscaras.

Batucada ou berimbau cresce.

Texto 17 (Tom intom) - O Bandido da Máscara Negra ou da Luz Vermelha, o popular Homem Macaco ou Homem Mascarado? Sete nomes diferentes para despistar a polícia; inclusive Carlos Augusto Teixeira, industrial; Mauro Vargas, falso inspetor de seguros; Perez Prado, falso fazendeiro do Rio Grande do Sul. Em cada lugar um nome; ex-garçom em Campo Grande; excamelô; vendedor de cortadores de unha na Av. São João; ex-porteiro de cinema de terceira linha; o Bandido da Luz Vermelha: primo de Mineirinho afilhado de crisma de D. Helder Câmara.

No início desta sequência, é a sucessão de perguntas que vai dando ritmo ao diálogo. Do estúdio vamos ao apartamento do Bandido e a entrevista continua pela televisão, em off (inclusive o monólogo de mais de meia página de JB). O Bandido desliga a TV e olha rua da Boca pela janela, vê Pivete e Lucho Gatica. Outro personagem, Alemão, entra "sempre silencioso e circunspecto". É interessante notar que em alguns momentos os personagens têm características não só físicas, mas também sonoras. Na cena seguinte, o Bandido volta a ligar a TV e a entrevista a JB volta a entrar por som e agora também as imagens, para então voltar para o estúdio onde o foco está no monólogo de JB e a "música cresce". Toda a ideia de montagem entre som e imagem, variando ons e offs está presente desde o roteiro. A forma da escrita, ao subverter as normas padronizadas de organização de um roteiro, já indica um filme que subverte a narrativa clássica.

Na escrita da cena 97, são as ações que sugerem sons: Bandido bate em Pivete, ela cai, depois rasga as roupas do Bandido.

É interessante como em muitos momentos o roteiro descreve não os sons, mas as ações, em caixa alta. Podemos dizer que os sons estão contidos, de forma implícita, nessas ações. Depois, a "Batucada ou berimbau cresce" e entra narração da voz over. Aqui cabe uma observação: já desde o roteiro estavam bastante claros os momentos em que a música, elemento narrativo sonoro bastante presente no filme, entraria. Assim, no filme, fica evidente que a realização previa a parte musical da trilha sonora. 
A análise dos elementos sonoros escritos no roteiro do "Bandido da Luz Vermelha" nos leva a concluir que a ideia audiovisual de construir uma obra em contraponto já estava em seu projeto.

"O termo contraponto deriva do latim punctus contra punctum, nota contra nota, ou ainda melodia contra melodia. Trata, portanto, de sons que se contrapõem simultaneamente. Basicamente, contraponto é direcionamento melódico. A chave para um bom contraponto entre as vozes é o tipo de direcionamento e contorno melódico que se estabelece no desenvolvimento das diferentes linhas melódicas.” (TRAGTEMBERG, 2002, p. 15)

Podemos considerar a definição musical de contraponto para nos aproximarmos dos recursos usados no roteiro literário de $O$ Bandido da Luz Vermelha e compará-los a uma partitura para uma obra em contraponto. Ao longo do relato escrito, existe uma preocupação de que o som não apenas reitere a imagem, mas a complemente ou contradiga. O som muitas vezes se descola da imagem; é independente, itinerante. Sons diferentes descritos como simultâneos sugerem a ideia de contraponto, como se pode perceber na análise cena a cena: os momentos em que a "música ye yé" complementa o sentido de ações de perseguição, por exemplo. A noção de contraponto também está presente na descrição da composição entre imagens e som (cenas mudas completadas por diálogos provenientes de outro tempo-espaço, por exemplo).

Em diversos momentos do roteiro, um elemento dramático-narrativo também desenvolvido em contraponto é o diálogo, como definido por Michel Chion. "O diálogo não pode ser um comentário da situação vivida, mas pode basear-se em outra coisa, no efeito de contraponto. É o procedimento do diálogo indireto: o que produz toda a sua força é sua indiferença diante da ação em curso (diálogo corrente e tranquilo durante uma cena dramática).” (CHION, 2002, p. 76, tradução minha) Em uma das primeiras sequências de perseguição ao bandido, por exemplo, transcorre um diálogo que nada tem a ver com a ação, sobre a forma como senhoras de idade caminham na rua e o risco de atropelá-las. Essa observação vale também para os momentos de relação entre letreiros escritos e diálogos em OFF: ora seus temas coincidem, ora são completamente diferentes. O mesmo acontece entre muitas das ações e a narração em OFF.

Por último, outro ponto que merece destaque é a ideia de silêncio presente no roteiro, que prevê algumas pausas na narrativa acelerada e fragmentada do relato: o "silêncio significativo" da 
cena 20, o "silêncio total" da cena 58, o "longo silêncio" da cena 90 e o "SILÊNCIO" da cena final. Essas pausas já previstas no roteiro mostram que a ideia de composição audiovisual já previa, antes da montagem, em pontos estratégicos, pequenos contrapontos entre som e silêncio na trilha sonora.

\subsection{O som no roteiro "literário"}

Consideramos, para as análises a seguir, roteiros que contêm em sua redação características que os aproximam da literatura. Eles contêm mais metáforas, figuras de linguagem e adjetivos que os roteiros "padrão" e "técnicos". Revelam, por meio do texto escrito, opiniões e intenções autorais que nos exemplos anteriores estão mais invisíveis ou implícitos. Aqui analisaremos sequências do filme $O$ pântano (2001, escrito e dirigido por Lucrecia Martel) e Girimunho (2011, escrito por Felipe Bragança e dirigido por Clarissa Campolina e Helvécio Marins). Começamos pela primeira sequência de $O$ pântano, transcrita abaixo (tradução minha).

\section{SÍTIO A MANDRÁGORA}

Tarde ainda ensolarada. Céu de tormenta que avança. Colinas muito verdes com desfiladeiros mais escuros. Alvoroço de pássaros que buscam refúgio. Ao longe já se vê a cortina cinza de água que avança. Escuta-se um disparo que vem das colinas. Os pássaros se calam. Silêncio.

Som áspero de algo que se arrasta.

No sopé das colinas há uns galpões de adobe e um casarão antigo. Entre os galpões um grupo de peões juntam os pimentões vermelhos que estavam secando ao sol e os arrastam em sacos de estopa para o galpão.

Outro som áspero de coisas que se arrastam.

Junto ao casarão um grupo de mulheres e homens cinquentões tentam arrastar com ridícula lentidão umas espreguiçadeiras brancas até a parte da piscina onde ainda há sol. Os corpos bronzeados, suados, magros e longos como se pertencessem à mesma família de homenspimentões. Se prestamos um pouco de atenção, é óbvio que estão completamente bêbados. Se movimentam com cuidado fazendo com que seja quase imperceptível o cambalear, em uma espécie de câmera lenta vergonhosa.

Tilintar de vidros. 
Uma mulher lida com sua espreguiçadeira enquanto na outra mão segura taças quase cheias. É Mecha. Se escuta outro disparo ao longe. Mecha fala para ninguém:

\section{Mecha-O Joaquin está com quem na colina?}

Ninguém responde, a não ser uma rajada de vento que arrasta um lenço de seda à piscina. O lenço tem uma cena equestre estampada. Mecha vê como os cavalos se afundam na água barrenta da piscina. Mecha olha para um homem em uma espreguiçadeira contígua. O homem é Gregório e está ajeitando o cabelo bagunçado pelo vento. O cabelo se enrola na aliança de casado. Tem uns sessenta anos, os olhos pequenos e vermelhos, e o cabelo suspeitosamente castanho. Mecha faz um gesto de leve desprezo e diz:

Mecha - Vamos ver se este ano você manda arrumar o filtro da piscina, Gregório... Não é o barro que está arruinando teu cabelo?

\section{QUARTO DE MOMI}

$\mathrm{O}$ vento se filtra pelas cortinas desbotadas pelo sol e balança um quadro de paisagem nevada que há perto da janela. A paisagem do quadro contrasta notavelmente com as colinas verdes e o sol que se vê quando as cortinas se mexem.

Deitadas sobre a cama há duas meninas. Uma tem cerca de quinze anos, o cabelo embaraçado e sujo. É Momi. O outra, a morena, é Isabel. Terá uns vinte e tantos anos. Momi veste um maiô. Isabel veste um avental de limpeza. Desabotoado e suado. Isabel dorme placidamente. Momi não. Está encolhida no pequeno espaço deixado na cama por Isabel. Momi move os lábios quase que imperceptivelmente. Apesar do ruído áspero das espreguiçadeiras sendo arrastadas e das risadas dos bêbados que entram pela janela é possível escutar o que Momi diz:

\section{Momi - Senhor, obrigada por me dar Isabel...obrigada por me dar Isabel..., obrigada por me dar Isabel...}

\section{FORA DA CASA}

Na piscina, uns lábios manchados de saliva verde de mascar folhas de coca dizem:

Homem 1 - Se chovem 45 milímetros, serão umas quatrocentas caixas por hectare...

O conjunto de espreguiçadeiras e seus proprietários estão já na restrita zona de sol da piscina. A julgar por como ficaram agrupadas é evidente que não há ninguém sóbrio. Mecha levanta os óculos de sol até deixá-los ridiculamente incrustados na testa. Olha a tormenta. Uma cortina cinza de água que avança. 


\section{Mulher 1 -Que delicia o cheiro dos pimentões, Mecha.}

\section{QUARTO DE MOMI}

Momi está espiando a piscina de sua janela. Olha com certa bravura. Vai até a cama onde Isabel ainda dorme e seca o suor da cara com um lençol. Isabel dormindo faz um gesto de incômodo. Momi sai de seu quarto.

\section{CORREDOR}

Caminha por um longo e amplo corredor até a porta. Entra devagar. A porta recém aberta deixa passar outro golpe de vento que balança um quadro do corredor. Outra paisagem nevada, um cachorro uivando para um céu cor de chumbo junto a um cordeiro morto.

\section{QUARTO DE VERÔNICA}

Este quarto tem aqui e ali pequenos enfeites baratos daqueles que as adolescentes gostam de colecionar, sem romper o austero bom gosto da casa. Sobre um quadro, cobrindo-o, está pendurada uma camiseta com um escudo de colégio particular. Na cama e também de maiô está

dormindo uma menina um pouco mais velha que Momi. É Verônica, irmã de Momi. Tem uns dezessete anos. Momi coça suas costas sem cuidado, para acordá-la.

\section{Momi - Tenho que te dizer uma coisa.}

Verônica se gira na cama mas não consegue acordar. As duas irmãs têm as roupas de banho quase secas. As cordas um pouco puxadas deixam ver as marcas brancas do tecido. Momi tenta abrir seus olhos com os dedos.

\section{Momi - Vai Vero acorda.}

Verônica faz um movimento para se liberar de Momi. Momi vai até a janela. Olha para a piscina.

\section{FORA DA CASA}

Na piscina, Mecha que tem os óculos de sol ridiculamente sobre a testa tenta ficar de pé com as taças vazias na mão. Mas volta a cair na espreguiçadeira. Disfarça sua intenção de ficar de pé. Outra vez se escutam disparos na colina.

\section{Mecha - O Joaquin está com quem na colina?}

Gregório move os lábios como se estivesse dizendo alguma coisa mas não sai nenhum som. $\mathrm{O}$ céu está completamente escuro sobre as colinas. Outra vez se escutam disparos como trovões. Uma mulher das que estão nas espreguiçadeira diz com a língua um pouco atada:

\section{Mulher 1 -Mecha... Que delicia o cheiro dos pimentões!}

Mecha sem escutar se acomoda em sua espreguiçadeira e bebe da taça vazia, diz em voz baixa: 
Mecha - Espero que Joaquin não venha sem o outro olho.

\section{SOPÉ DA COLINA}

Chove no monte fechado e verde do sopé da colina. A câmera corre rápido atrás de um menino de uns catorze anos que tem uma escopeta na mão. É Joaquin. Avança sem se preocupar com os ramos espinhosos da vegetação. Ajudando-se com a culatra da escopeta para abrir caminho. Se escutam baforadas e latidos de cachorros que o acompanham. De repente se detém. Olha para cima das árvores altas. Alguém atrás dele fala.

\section{Voz em off-Aí, atrás do arbusto!}

Joaquin levanta a escopeta e avança outra vez a grande velocidade entre os ramos. De repente cambaleia. Os tênis se afundam na lama mole. Avança com mais dificuldade, as pernas cada vez mais enterradas na lama. Chega a um clarão. Para repentinamente. Joaquin vira para a câmera. Podemos ver sua cara por primeira vez. Falta-lhe um olho, as pálpebras do olho que falta se afundam sobre a órbita vazia, dando ao conjunto da cara um aspecto selvagem e malévolo. Tem a testa molhada de suor, com marcas de arranhões das folhas. O cabelo emaranhado.

\section{Joaquin-Pobre bicho!}

A Câmera avança passando pelas costas de Joaquin. No meio de um pântano há uma vaca enterrada até a metade da barriga. $\mathrm{O}$ animal está quieto. Ao redor a lama está mexida, como se tivesse feito grandes esforços para sair. Mas agora parece cansado e entregue, apesar dos latidos dos cachorros.

\section{QUARTO DE VERÔNICA}

Momi está sentada perto dela na cama, está chorando. Verônica olha para ela sem conseguir despertar-se completamente.

\section{Verônica-Que foi? Que foi? \\ Momi - É muito importante... Acorda, você tomou remédio?}

Verônica percebe que Momi está chorando e acorda um pouco. Momi aperta os olhos com as mãos. Verônica começa a jorrar lágrimas mas não se aproxima de Momi.

\section{Verônica (Entre soluços) - Já sei o que é...eeu já sabia.}

Momi levanta a cabeça surpresa ao escutar que sua irmã também chora. E as duas choram mais ainda ao se verem cheias de lágrimas. Mas Momi abruptamente fica brava.

\section{Momi - Você não sabe!}


Momi coça suas queimaduras de sol deixando marcas brancas que desaparecem lentamente. Momi sorve as lágrimas. Mas Verônica não responde regozijando-se em suas próprias lágrimas.

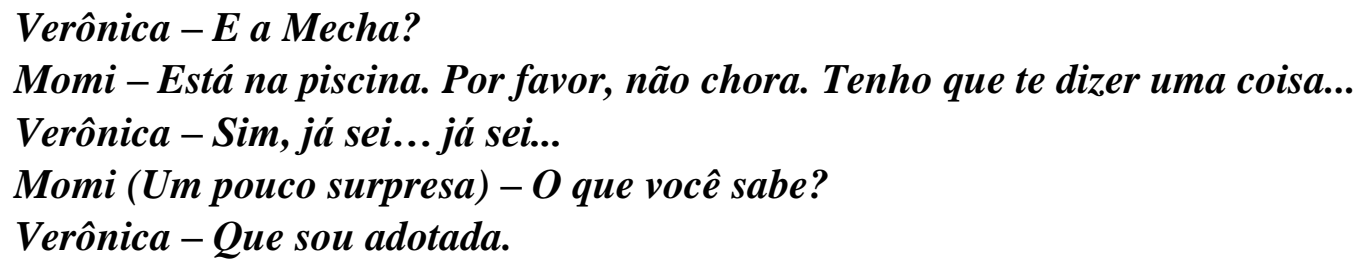

Momi volta a chorar e Verônica a acompanha com a mesma força. Momi começa a rir. Verônica olha para ela desconcertada.

$$
\text { Momi - Não. Não. }
$$

Mas Verônica volta a chorar com mais força agora, afirmando com a cabeça seu terrível destino. Momi fica um pouco brava e lhe dá um tapa na cabeça.

\section{Momi-Para de chorar. Você não é adotada. \\ Verônica - E você o que sabe, se é mais nova que eu?}

Momi fica um segundo calada, pensativa. Afasta os cabelos da cara de sua irmã um pouco torpemente, pois está brava.

Momi - Não somos adotadas, Vero. De verdade. É outra coisa...Não fala pra ninguém...É a Isabel.

Verônica seca as lágrimas e olha para a irmã sem entender.

Verônica - Você encontrou as toalhas?

Momi (aborrecida) - Ela não rouba as toalhas, Vero.

Momi volta a chorar.

Momi - Não quero estar com ninguém, só com a Isabel.

Verônica olha para sua irmã e vai ficando brava enquanto seca suas lágrimas.

Verônica - Outra vez Momi...Onde está Isabel?

Momi - Na minha cama.

Verônica - A Mecha vai mandar ela embora.

Momi - Se ela mandar a culpa é tua que fica acusando ela.

Verônica - Ninguém me escuta.

Momi-Te escutam sim. E se a mamãe mandar ela embora é por causa das toalhas. 
Verônica - E eu?

Momi - Vero, estou falando de mim e da Isabel. Eu estou falando, Vero.

Verônica - E se ela mandar?

Momi - Vou sair de casa. E não vou voltar para nada.

Verônica volta a chorar. Momi tentada por sua irmã também verte algumas lágrimas.

Verônica - Não vai embora, por favor. Não vai.

Verônica colocou um ênfase dramático nestas palavras que faz Momi reagir.

Momi - Chega Vero. Me encheu.

Verônica - Mas, e se mandam a Isabel embora?

Momi - Por que vão mandar ela embora?

Verônica - Porque Mecha diz que desaparecem lençóis e toalhas...

Momi fica muito triste e chora amargamente.

Momi - É mentira. Isabel é muito boa. É melhor que nós.

Verônica chora sem escutar, mergulhada em sua própria e íntima desgraça.

Verônica - Eu acho que sou adotada e ninguém me diz... eu sei...

Momi (De repente violenta) - Não é verdade, não chora por isso, vou te matar. Idiota.

Momi olha para sua irmã transformada em um mar de lágrimas, se levanta da cama enfurecida. A conversa foi um fracasso.

Momi (bravíssima) - E chega de chorar. Idiota chorona.

Momi se aproxima da janela. Verônica se ofende mas em seguida se distrai com um fio azul que escapa de seu maiô. Momi está olhando para as colinas. Escuta-se outro disparo. Momi muda de tom de repente.

Momi - Joaquin, levou meu tênis. Deve estar enlameado. Daqui a pouco vai chover aqui.

FORA DA CASA

Neste momento, Mecha que ainda tem uma taça vazia na mão e os óculos de sol na testa, tenta ficar de pé, e cambaleando um pouco vai se apoiando nas espreguiçadeiras próximas à piscina e recolhendo umas seis taças. A instabilidade da mulher é tal que a cada passo parece que vai cair. Consegue acomodá-las em uma bandeja e caminha em direção à casa. Mas um pé se enrosca em uma toalha de banho e cai bruscamente sobre a bandeja de taças. Estouro de vidros. E um 
gemido. Mecha, com o queixo apoiado na bandeja e o olhar fixo na mão que tem uma aliança de casamento, fala em voz baixa:

Mecha-Ai! Gregório, olha o que você me fez...

\section{CORREDOR}

Momi corre até a escada. Para e corre até seu quarto.

QUARTO DE MOMI

Isabel está acordando. Momi fala rápido como em alerta de incêndio

\section{Momi - A Mecha caiu.}

CORREDOR

Isabel e Momi correm até a escada. Verônica da porta de seu quarto grita quando elas passam:

\section{Verônica - Não quero ver sangue!}

Momi segue Isabel com um estranho entusiasmo. Como se fossem uma equipe de policiais de resgate.

\section{FORA DA CASA}

Na piscina o restante dos convidados não conseguiu desgrudar-se de suas espreguiçadeiras. Alguns nem perceberam o que acontece. Menos Gregório que cambaleia do borde da piscina até onde está a mulher acidentada que continua jogada sobre a bandeja. Vai e vem sem poder sequer agachar-se.

\section{Gregório - Vai chover, Mecha. Levanta.}

Isabel e Momi levantam Mecha do chão. Um jorro de sangue se esparrama sobre os vidros quebrados. Mecha, agora que viu seu sangue, parece um pouco assustada, Isabel e Momi a sentam em uma espreguiçadeira. Momi acomoda seus óculos sobre os olhos.

\section{Mecha-Estou bem. Estou bem. Não sei o que aconteceu. Caiu minha pressão.}

Isabel deixa Mecha nas mãos de Momi e corre até a casa. Volta com toalhas. Momi olha para ela um pouco envergonhada. Isabel envolve o braço da mulher que tem um corte longo e profundo. Coloca sobre seu peito outra toalha. No peito tem vários cortes, alguns bastante grandes. As toalhas logo se encharcam de sangue. A mulher olha para as toalhas e depois para Isabel.

\section{Mecha-Agora aparecem as toalhas por todos lados.}


Isabel não liga para o comentário. Momi olha para Isabel com desconfiança. Isabel devolve a Momi um olhar de incômodo e diz:

\section{Isabel - Traz o carro até o jardim}

Momi obediente mente sai correndo em direção à casa.

\section{QUARTO DE VERÔNICA}

Momi entra no quarto da irmã, que está terminando de se vestir.

\section{Momi - Vero, se troca que temos que levar ela pro hospital. Verônica - Não viu que estou me trocando? \\ Momi - Você viu as chaves do carro? \\ Verônica - Estão com o Gregório no criado mudo. Se machucou muito?}

\section{CORREDOR}

Momi corre até o quarto da mãe.

\section{QUARTO DE MECHA}

Gregório está sentado na cama com o olhar perdido e uma camiseta das que têm um jacaré.

Momi sem prestar muita atenção procura nas gavetas dos criados mudos. Gregório olha agora para os dorsos de suas mãos. Tem a pele manchada pela idade.

\section{Momi - Pai, onde estão as chaves do carro? \\ Gregório - Estão no contato. Já vou.}

\section{FORA DA CASA}

Um carro caro, bastante maltratado e com o rádio no volume máximo, entra a grande velocidade de ré no jardim. Mecha vê como o carro esmaga umas hortênsias. A música da rádio é um tema da Gloria Ganor: I will survive. Mecha diz a Isabel, que está trocando uma toalha encharcada de sangue por outra seca.

Mecha - Com o trabalho que deu para fazer as hortênsias pegarem! Vai parar essa criatura!

Isabel sai correndo até o carro com a toalha encharcada de sangue.

Isabel -A senhora disse para você não fazer confusão.

Mecha grita de onde está. 


\section{Mecha - Isabel!}

Isabel olha para Momi que está muito nervosa procurando o botão para desligar o rádio. Isabel segura a cara de Momi com as mãos. Momi se detém e olha para Isabel. Momi está à beira das lágrimas. Isabel fala com muita tranquilidade.

Isabel - Momi, liga para o doutor Conrado. Avisa que vão pra lá. Está perdendo muito sangue.

Momi respira fundo aliviada. Isabel se distancia. Momi desliga o rádio.

\section{SALA DA CASA}

Quando Momi está discando o telefone escuta gritos de Mecha que a chama. Momi desliga e corre até a piscina.

\section{FORA DA CASA}

Isabel está tentando colocar Mecha, que está em roupa de banho, no carro. Mecha resiste. Começa a cair água em forma de gotas enormes.

\section{Mecha - Momi, me traz um vestido com botões. Esta índia quer me fazer descer assim até a Ciénaga.}

Isabel e Momi correm até a casa. No caminho conversam.

Isabel - Está saindo todo o sangue dela, fala para o Sr. Gregório que vai morrer se não se apressarem.

Momi para um instante. Isabel se perde em uma das portas da galeria. Momi percorre a cena com o olhar. Os convidados bêbados se balançam até os carros arrastando toalhas e roupas. Um está apoiado no capô do carro tentando reativar a circulação de uma de suas pernas que dormiu. Chove. Mecha debilmente apoiada na espreguiçadeira conversa com uma mulher que, alheia ao acidente, tenta colocar umas sandálias de praia. Mas, estranhamente, a mulher, cada vez que consegue calçar a sandália, volta a tirá-la e tenta de novo. Momi reage e corre até o quarto da mãe.

QUARTO DE MECHA

Encontra Isabel procurando algo no armário.

\section{Momi (Desconcertada) - O que você está procurando?}

Isabel, sem ligar para a pergunta, tira um vestido com botões e corre escadas abaixo. No banheiro Gregório está secando o cabelo com um secador. 
Momi - Se você não levar ela já para um hospital a mamãe morre.

Gregório - Confere o que a Isabel levou.

Gregório diz isso e se fecha no banheiro. Momi sai para a piscina.

\section{FORA DA CASA}

Isabel está tentando ajudar Mecha a se vestir. Quando Momi chega, Isabel sai de novo correndo. A chuva espalhou o sangue de Mecha deixando a espreguiçadeira ilhada em uma poça rosada sobre as majólicas brancas do chão. Isabel volta com mais toalhas secas. A um lado outra empregada vai juntando as toalhas empapadas de sangue e vai colocando em um balde. Mecha a vê.

\section{Mecha - Nem pensa em lavar as toalhas com água quente.}

Momi se aproxima de Isabel que tenta enrolar com a toalha o braço da mulher. Fala com Isabel em tom baixo.

$$
\begin{aligned}
& \text { Momi - Não para, né? } \\
& \text { Isabel-Coloca os sapatos nela. }
\end{aligned}
$$

O vestido abotoado se mancha de sangue. Mecha tenta secá-lo.

Mecha - Vai buscar outro, isto é uma vergonha.

Momi. (com estranha calma) - Mamãe, está chovendo, entra no carro.

Mecha. (Olhando para sua filha, com medo de sua própria morte) - Esta chuva vai fazer bem ao campo, Momi.

Mecha entra no carro obediente. Verônica está na galeria discutindo com Gregório.

Verônica - Deixa que eu dirijo, pai. Você fica. Não vê como está?

Gregório - Mas pelo amor de Deus. Não é o momento...

Momi grita do carro para sua irmã, Verônica e Gregório que cambaleia, vão até o carro. Verônica sobe ao volante e Gregório com Mecha no banco de trás. Momi se aproxima da janela e fala com Verônica sem que as escutem atrás.

A chuva bate no carro com força. Momi tenta controlar a situação, apoia sua mão no queixo de sua irmã, que está bastante nervosa.

Momi - Se vocês não chegarem rápido, ela pode morrer. Mas não fica nervosa.

Verônica - Você não vem?

Momi - Vou localizar o Gringo Conrado no hospital pra ele esperar vocês.

Verônica (Está aturdida) - Liga para o Gringo Conrado. Tem sangue em toda parte. 


\section{Momi - Vero, você está me ouvindo? Não deixa o Gregório dirigir. \\ Verônica - E se a polícia me parar? \\ Momi-Diz que esqueceu a carteira e que é uma desgraça. \\ Verônica - Sim, é uma urgência.}

O carro vai até um portão que está a uns cem metros da piscina. O carro para e começam as buzinadas. Isabel sai correndo e abre o portão. O carro vai embora.

Isabel volta até a galeria. Caminha um pouco abatida. Tem o avental completamente manchado de sangue. Isabel olha para Momi, está parada na galeria mas não se protege da água que entra com o vento. Momi está tremendo de frio e o sangue que estava em seu maiô escorre por suas pernas com a água. Isabel jorra água de chuva e está chorando. Mas Momi não percebe. Isabel pergunta:

\section{Isabel - Você ligou para o Gringo?}

Momi reage. Sai correndo até o interior da casa. Isabel e a outra empregada recolhem os vidros e as toalhas debaixo da chuva.

Pelo caminho até os galpões, que estão a uns cem metros de distância da casa, vêm correndo Joaquin com lama até os joelhos, a escopeta e cachorros sem raça dando gritos ao redor. Joaquin corre com a cabeça de lado para olhar o caminho com um só olho.

\section{SALA DA CASA}

Ao telefone está um dos convidados. É o homem dos lábios verdes por mascar coca. Está falando com alguém e não consegue parar de rir. Momi se aproxima impaciente.

\section{Momi - Tenho que ligar para o médico.}

O homem olha para ela concordando e seca as lágrimas.

Homem 1 - Bom, bom. Tchau Gringuito e obrigado... (Olhando para Momi com cara de dever cumprido) Já avisei o Gringo Conrado e ele vai esperar vocês no hospital. Ai, este Gringo, me faz rir. A sogra não quer que a opere porque uma vez deixou uma colher dentro de um matambre.

Momi olha para ele com seriedade e concorda. Não o escutou.

O processo criativo de Lucrecia Martel, como vimos na introdução a esta dissertação, tem no som um de seus pilares. Por isso, decidi buscar na escrita de um de seus roteiros elementos que ajudassem a entender como o roteiro é uma ferramenta para a construção de sons expressivos 
no filme. O trecho escolhido, que tem cerca de 11 páginas, corresponde à primeira sequência do filme, que vai até o minuto 9. O final da penúltima cena e a última cena da sequência ficaram fora do filme (onde a sequência termina com a partida do carro). A edição suprimiu alguns momentos descritos ao longo da sequência (principalmente no interior da casa) e alterou a ordem de outros. Algumas ações indicadas aos atores também foram alteradas na mise-en-scène.

A primeira observação que podemos fazer diz respeito à forma da escrita, um pouco fora do padrão (a disposição dos diálogos, por exemplo) e com um caráter mais "literário", expresso nas palavras que emitem opiniões ou subjetividades: "mulheres e homens cinquentões tentam arrastar com ridícula lentidão umas espreguiçadeiras brancas"; "A conversa foi um fracasso"; "Momi segue Isabel com um estranho entusiasmo. Como se fossem uma equipe de policiais de resgate."; "Falta-lhe um olho, as pálpebras do olho que falta se afundam sobre a órbita vazia, dando ao conjunto da cara um aspecto selvagem e malévolo". Estas licenças poéticas, ou literárias, ajudam a dar o tom da narrativa, além de fazer com que o texto do roteiro seja mais longo que o padrão. Outro fator que "alonga" o texto é o fato de ele descrever em alguns momentos diferentes camadas narrativas audiovisuais simultâneas, como veremos abaixo.

Com relação à descrição do som, é possível elaborar uma série de observações. Primeiramente, há fenômenos descritos a partir do som que têm começo, meio e fím, criando o que podemos chamar de pequenas tramas sonoras. Por exemplo, a dos pássaros: "Alvoroço de pássaros que buscam refúgio"; "Um disparo"; "Os pássaros se calam"; "Silêncio". Essas pequenas tramas descrevem processos simultâneos aos processos descritos nas tramas principais.

O segundo aspecto da escrita que podemos destacar é o uso de verbos e adjetivos que descrevem e evocam informações sonoras: "Som áspero de algo que se arrasta"; "Tilintar de vidros"; "Ninguém responde, a não ser uma rajada de vento que arrasta um lenço de seda à piscina". Apesar de não aparecerem no filme tal qual descritos no roteiro, o arrastar de cadeiras, o som do vento e os barulhos de vidros chocando-se, recebendo líquido e quebrando-se são sons protagonistas na sequência analisada, que está gravada de modo a dar espaço e tempo para que esses sons se manifestem e se desenvolvam.

A terceira característica da escrita da sequencia analisada que merece destaque é a que diz respeito às descrições que antecedem os diálogos. Formas de falar, entonações e a presença de 
outros sons junto ao diálogo estão escritos em palavras de roteiro, assim como a proximidade ou distância da fonte sonora: "Momi move os lábios quase que imperceptivelmente. Apesar do ruído áspero das espreguiçadeiras sendo arrastadas e das risadas dos bêbados que entram pela janela é possível escutar o que Momi diz"; "Na piscina, uns lábios manchados de saliva verde de mascar folhas de coca dizem"; "Gregório move os lábios como se estivesse dizendo alguma coisa mas não sai nenhum som"; "Uma mulher das que estão nas espreguiçadeiras diz com a língua um pouco atada". Em alguns casos, a caracterização da fala vem antes e depois do diálogo: "Verônica (Entre soluços) - Já sei o que é...eu já sabia. Verônica colocou uma ênfase dramática nestas palavras que faz Momi reagir." Neste último exemplo, a ação é descrita como algo passado, característica que aproxima mais uma vez o texto da literatura.

Em quarto lugar, a escrita também faz uso do som para relacionar os três espaços principais da trama (colinas, piscina e casa) e descrever diferentes camadas da narração: "Mas volta a cair na espreguiçadeira (...) Outra vez se escutam disparos na colina."; "O céu está completamente escuro sobre as colinas. Outra vez se escutam disparos como trovões"; "Se escuta outro disparo. Momi muda de tom de repente".

Em termos dramatúrgicos, e em quinto lugar nesta análise, podemos dizer que o clímax da sequência é marcado por uma pequena trama de sons: "Estouro de vidros. E um gemido. Mecha, com o queixo apoiado na bandeja e o olhar fixo na mão que tem uma aliança de casamento, fala em voz baixa." A partir deste momento, há uma mudança no ritmo da sequência: tudo se acelera. Um exemplo disso é a escrita dos diálogos: "Momi fala rápido como em alerta de incêndio"; outro é a descrição das ações: "Um carro caro, bastante maltratado e com o rádio no volume máximo, entra a grande velocidade de ré no jardim."

A sexta observação a ser feita diz respeito ao pensamento sobre a música dentro da trama. O roteiro prevê uma música diegética, que vem do rádio do carro, que, além de influir nas ações dos personagens (Momi tem trabalho para desligar o rádio), altera sua comunicação (precisam falar mais alto para se entenderem). A música sugerida no roteiro é I will survive, a qual daria um tom diferente daquele expressado pela música escolhida (Mala mujer, um tema em castelhano menos conhecido) na edição final, semantizando tudo o que vem depois até Isabel desligar o rádio. No roteiro, o rádio demora mais para ser desligado, há um diálogo maior enquanto a 
música toca, há mais ações de Isabel e Momi. Outro som que ajuda a construir o ambiente sonoro e o tom da cena é o do secador de cabelos de Gregório, presente no roteiro.

Os sons preponderantes na parte final do roteiro e da sequência, além de alguns diálogos, são o da chuva e o da buzina do carro, que no filme funciona como transição para a sequência seguinte.

A sequência termina com "Momi olha para ele com seriedade e concorda. Não o escutou." Esta última frase pertence ao fragmento da sequência que ficou fora do filme. É interessante notar a observação sobre a ação de Momi: além de estar escrita no passado, pertencendo ao mundo da literatura, refere-se a um comportamento relacionado ao som, a ação de não escutar. Apesar dessas informações não serem visíveis ou audíveis, ajudam a caracterizar o estado de espírito da personagem, que poderia ser transmitido pela atriz.

Girimunho, por sua vez, é o exemplo mais híbrido dos escolhidos para análise. Isso porque se trata de uma obra que transita entre o documentário e a ficção, e o filme se distancia do roteiro. A sequência que escolhemos foi a primeira, transcrita abaixo:

Créditos iniciais em silêncio - ruídos de martelo OFF contra o metal - tac tac tac - uma voz abafada de televisão ao fundo... e um apito de barco a vapor ressoando - puuu, puuu, puuu.

INSERT - Um redemoinho de poeira, folhas e vento no meio da ruazinha vazia de cidade do interior...

CARTELA:

Girimunho pode ser um peixe, pode ser redemuinho, pode ser o jeito como o mundo gira... ainda não pesquisei o suficiente nas minhas ideias... Mas acho que é isso. Não é não, moço?

O redemoinho se desmancha no ar...

Corta:

1. INT. OFICINA DE FELICIANO - DIA 
A luz entra por uma janela de metal trançado - desenha na parede algumas formas vagas. Um homem FELICIANO, 82, rosto forte e mulato, está com os olhos no vazio como se ouvisse uma voz vindo de longe. Ele olha e escuta... Na mão, um pequeno alicate abre e fecha. Puuu, puuuu o apito do navio a vapor ao longe.

Uma vozinha feminina, cansada, aparece ao longe.

\section{BASTIANA \\ Feliciano?... Feliciano?... (pausa) Cê num vai ir ver o Vapor?}

Feliciano olha pra ela.

É uma senhora numa porta que leva da oficina para dentro de uma casa - mãos na cintura: é SEBASTIANA, 81 - vestido de pano, rosto magro.

Feliciano olha a rua lá fora e fica assim.

Corta: Feliciano vai concertando uma espingarda. Concerta, concerta. Ao longe, os fogos e o barulho da festa.

\section{FADE OUT. ENTRA TÍTULO - FADE IN: GIRIMUNHO}

Como mencionamos, há uma diferença grande entre começo do filme e começo do roteiro: a primeira cena do roteiro (indicada com o número 1 no texto, após o prólogo) corresponde à segunda sequência do filme, que começa aproximadamente aos 8 minutos e 30 segundos e mesmo assim é bem diferente. $\mathrm{O}$ interessante é que as marcações sonoras podem ser reconhecidas na "tradução livre" do roteiro ao filme, onde a sequência começa com um som de vento e batidas ritmadas. A personagem no escuro é uma mulher.

As primeiras frases do roteiro fazem referência a diferentes fontes sonoras, descrevendoas e fazendo uso de onomatopeias para caracterizá-las: "tac, tac, tac"; "puuu, puuu, puuu." 
$\mathrm{Na}$ descrição do primeiro personagem, os roteiristas recorrem a uma escrita literária e poética, em que buscam, por meio de reticências e referências à subjetividade do personagem caracterizar o ponto de audiovisão de Feliciano e o espaço ao redor: "está com os olhos no vazio como se ouvisse uma voz vindo de longe. Ele olha e escuta... Na mão, um pequeno alicate abre e fecha. Puuu, puuuu - o apito do navio a vapor ao longe."

Bastiana é apresentada pelo som de sua voz, qualificada como "uma vozinha feminina, cansada", que "aparece ao longe". Quando ela fala, o roteiro incorpora características da forma de falar informal: "Cê num vai ir ver o Vapor?". Podemos identificar, assim, uma busca por captar a sonoridade e o ritmo das falas, do sotaque, a partir da escrita dos diálogos. Apesar das diferenças entre a sequência do roteiro e a sequência do filme, o texto escrito estabelece algumas intenções sobre tom, ritmo e estética da obra.

\section{4 É possível traduzir palavras em sons?}

A partir das análises acima, podemos entender que, apesar de pertencerem a universos diferentes, palavras e sons podem estabelecer uma relação entre o roteiro e o filme. Assim como o roteiro não é o filme, as palavras não são os sons, mas o roteiro revela-se como um importante instrumento para estabelecer o espaço e a participação do som no filme.

É possível identificar na escrita dos roteiros analisados diferentes recursos que servem como base para um posterior uso ou desenvolvimento do som na narrativa audiovisual. Em alguns casos o que contém informação sobre o som é destacado com letras em negrito ou itálico,

ou ainda em caixa alta. Algumas vezes, são escolhidos verbos que remetem a sons (arrastar, por exemplo), ou adjetivos que caracterizem um som (como risada abafada), ou ainda onomatopeias. Outras vezes, as ideias sonoras estão contidas em elementos “invisíveis", como o ritmo da escrita das ações e dos diálogos. Em outras situações, as indicações de som estão nas rubricas que indicam a entonação dos diálogos, ou nas indicações de pausas e silêncios.

Os exemplos analisados mostram que a forma da escrita varia bastante, aproximando-se ou distanciando-se da formatação sugerida pelos manuais. O que é comum a todos os roteiros é o fato de que preveem o som para que ele possa ser parte fundamental do relato. 


\section{Considerações finais: como se escreve o som?}

Afinal, como se escreve o som? Retomamos, aqui, as questões propostas no início desta dissertação. A primeira delas é: quais as possibilidades e limitações de descrever o som com palavras?

Nossas observações sobre os diferentes aspectos do som como elemento narrativo nos levaram a perguntar até que ponto o som pode ou deve ser escrito com palavras. A palavra é, ao mesmo tempo, a principal ferramenta e a principal limitação do roteirista. Sons e imagens não são palavras. O roteiro, portanto, não é o filme escrito. Como afirma Eliseo Altunaga, em entrevista ao roteirista chileno Julio Rojas,

O roteiro não é o filme. E, além disso, há vezes em que o roteiro não tem nada a ver com os meios expressivos que o filme emprega. $\mathrm{O}$ roteiro tem seus próprios meios expressivos: o roteiro não é contar o filme em um papel, porque os filmes não podem ser escritos. Os filmes têm que ser filmados, rodados, atuados, iluminados, sonorizados, editados. Esse é o filme. O roteiro não é isso. Não é nem a atuação, nem a câmera, nem o som, nem a imagem, nem a edição. O roteiro é a partitura, nas relações que se criam no espaço, no tempo e no ritmo. O roteiro é uma condição à parte. Digamos, a partitura não é a música: se você a dá a um músico ruim, ele não faz nada com isso, mesmo que Beethoven a tenha escrito. A música se faz na interpretação. E o filme na rodagem. (ROJAS, 2016, p. 40, tradução minha)

Se o roteiro é a partitura, para poder compor bem os roteiristas precisam conhecer os códigos da narrativa audiovisual. O primeiro passo para isso é aprender a ouvir e entender o uso do som, suas possibilidades. Essa escuta é a escuta do cotidiano, das formas de falar das pessoas, das narrativas orais, dos ambientes que frequentamos. É também a escuta atenta dos filmes, seus efeitos, ruídos, vozes e músicas. Das relações entre trilha sonora, imagens e montagem. Das possibilidades de relações entre sons e personagens e também das possíveis relações entre sons e espectador.

A partir dessa consciência do som o roteirista pode desenvolver uma partitura audiovisual em que a trilha sonora esteja contemplada; escrever um roteiro que contenha palavras e informações que indiquem a presença de som no espaço, nas ações, nos movimentos (seja esse som diegético ou extradiegético). Pode, além disso, escolher dar protagonismo a determinado 
componente dessa trilha, que além de participar do espaço passa a ter uma função parecida a de um personagem ou a de um acontecimento que pode mudar o rumo da ação, ou que pode ser indispensável para o entendimento do relato.

Nossa segunda pergunta é: Qual o espaço do som na forma do roteiro audiovisual?

Vimos, nas análises dos manuais de roteiros e de sequências de roteiros, que a presença do som pode ser descrita formalmente no roteiro. Além dos sons emitidos por vozes, indicados nos diálogos, os roteiristas podem descrever características sonoras do espaço, dos objetos e das ações. Podem, além disso, indicar a presença de sons extradiegéticos. Existe a possibilidade dessas descrições serem destacadas por maiúsculas, negritas ou qualificadas por adjetivos. Mas a forma física, gráfica de descrever o som não torna um roteiro mais ou menos sonoro. $\mathrm{O}$ uso de negritas ou maiúsculas, inclusive, pode encobrir o fato de que o som não foi concebido de forma a integrar o relato de modo expressivo ou dramático. Como vimos no Capítulo 2, o destaque do que soa pode apenas reforçar o som do que já estamos vendo, sem necessariamente contribuir para a composição de uma trilha sonora mais complexa. O importante é que o autor busque a escrita que estimule nos leitores do roteiro a levar em conta a trilha sonora. Os leitores do roteiro são diferentes membros da equipe que vai realizar o filme: diretor, atores; diretores de fotografia, de arte e de som; produtores; figurinistas, etc. São pessoas que participam do processo criativo, ou que "executam a partitura" e precisam ter as bases para traduzir palavras em diferentes aspectos audiovisuais, inclusive o som.

O som pode ser considerado como elemento potencialmente dramático. Os sons presentes no espaço podem afetar os personagens mesmo que não afetem diretamente a ação. É interessante que o roteirista se pergunte o que ouvem os personagens, como se relacionam com os sons do espaço em que vivem, e que se ponha, como citamos na introdução desta dissertação, a "pensar em como soa a nossa história, no que escutam os personagens e em como o som influi em suas ações e emoções, como na vida" (LABRADA, 2009, p. 52, tradução minha). Assim, os sons das sequências podem contribuir para a construção do perfil do personagem e de seu caráter. Podem, ademais, transmitir sentimentos e ideias.

A partir dessa tomada de consciência da presença do som, podemos responder a terceira pergunta: Existe um tipo de escrita que favoreça o som? Mais que uma forma favorável de 
"escrever" o som, o importante é que o autor leve em consideração a presença do som nos espaços, ações, personagens e imagens que descreve no relato audiovisual. No Capítulo 3, observamos diferentes formas de escrita de roteiro, mas não é possível afirmar que o desrespeito às "regras" necessariamente gere roteiros mais sonoros. O importante é que o som seja levado em conta, e que o roteirista busque a melhor forma de escrever o que quer expressar. Para isso, pesarão seus conhecimentos não só sobre o som, mas também sobre o(s) gênero(s) dramáticos(s) que está desenvolvendo, o tipo de relação que quer estabelecer com o espectador, o ponto de vista, o espaço e os personagens.

Até que ponto um som indispensável na compreensão de uma narrativa pode ou precisa ser pensado desde o roteiro? Se o som tem função dramática na trama, o mais provável é que tenha sido considerada desde a etapa do roteiro. Mas para que o som seja explorado em todas as suas possibilidades o roteirista precisa conhecer quais são elas. E os manuais de roteiro provavelmente não são a melhor base para este tipo de conhecimento: percebemos, na análise dos manuais de roteiro feita no Capítulo 1, que o som é um componente narrativo pouco explorado por aqueles que se dedicam a dar conselhos e sugestões sobre como escrever um roteiro. Por que isso acontece?

Comparado com o fluxo de contribuições centradas na imagem, o silêncio dos acadêmicos sobre o som nos meios audiovisuais foi muitas vezes ensurdecedor. Esta ênfase visual nos estudos do cinema pode ser produto da tendência visual da cultura ocidental. A primazia da imagem no meio audiovisual também pode ser decorrente da indefinição do som como objeto. Aparentemente faltam ferramentas para aspectos sonoros de filmes que não são a música, e mais ainda para descrever o som em si. Por sua difícil natureza (na vida cotidiana, frequentemente recorremos a metáforas visuais ou tácteis para descrever o som), o som é usualmente considerado pelo que significa ou pelo que representa do que por si mesmo. (LE FÈVREBERTHELOT, 2013, p. 2, tradução minha)

Assim, retomamos nossa principal pergunta: como é possível escrever uma trilha sonora narrativa e dramaticamente significativa a partir do desenvolvimento do roteiro audiovisual? Podemos afirmar que, primeiramente, um roteirista deve conhecer as possibilidades do som para poder empregá-lo como componente argumental em seus relatos, em uma relação dialética com a imagem. Por outro lado, é importante conhecer as possibilidades e limitações do relato escrito. O roteirista também deve levar em conta que um roteiro é uma relação, um pacto entre quem 
escreve e quem lê. E parte deste pacto consiste em sugerir, nem sempre de forma direta ou visível, sons e imagens, ritmo e cadência.

A técnica do roteiro é sobretudo fundada sobre essa colaboração por parte do leitor, e compreendemos que sua perfeição reside no cumprimento perfeito dessa função. Sua forma, seu estilo, são perfeitos e completos quando se compreende essa necessidade. A impressão de imperfeição e incompletude é, portanto, apenas aparente. Uma tal imperfeição, uma tal incompletude são elementos estilísticos. (PASOLINI, 1982, p. 78, tradução minha)

Nossa reflexão sobre a escrita do som nos leva a uma reflexão sobre a escrita de relatos audiovisuais em geral, no sentido de que nos ajuda a ter uma consciência de que tipo de roteiro se está escrevendo, de que filme estamos vislumbrando. A necessidade de escrever um roteiro, ou de tê-lo como ponto de partida de um projeto audiovisual, não é necessariamente uma limitação. A "obrigatoriedade" de escrever um roteiro e tê-lo como guia para um filme pode ser vista como a possibilidade não de "escrever o filme", mas como uma instância de reflexão, planejamento do filme, onde se incluem seu som e as relações entre trilha sonora, imagens e ações. 


\section{Bibliografia}

ABBATE, Carlos. Cómo hacer el sonido de una película. Buenos Aires: Libraria, 2014.

ALTMAN, Rick (Ed.). Sound theory/sound practice. New York: Routledge, 1992.

AUMONT, Jacques; MARIE, Michel. Dicionário teórico e crítico de cinema. São Paulo:

Papirus, 2003.

BARNES, Randall. Barton Fink: atmospheric sounds of the creative mind. Offscreen, v. 11, n. 89, p. 1-23, aug./sept. 2007.

BARRERAS, Eliseo Altunaga. Hoy se hacen novelas que se vendan, como se hace el cine que se vende. Entrevista a Marcela Mazzei. El Clarín, Buenos Aires, 25 set. 2013. Revista N.

Disponível em: <http://www.revistaenie.clarin.com/escenarios/cine/Entrevista-EliseoAltunaga_0_998900559.html> Acesso em 17 ago.2016

BELTON, John; WEIS, Elisabeth (Ed.). Film sound: theory and practice. Nova Iorque: Columbia University Press, 1985.

BORDWELL, David. La narración en el cine de ficción. Barcelona: Paidós, 1996.

BORDWELL, David; THOMPSON, Kristin. Fundamental aesthetics of sound in the cinema. In: BELTON, John; WEIS, Elisabeth (Ed.). Film sound: theory and practice. Nova Iorque: Columbia University Press, 1985. p. 181-199.

BORDWELL, David; THOMPSON, Kristin. Arte cinematográfico. Mexico-DF: McGraw Hill, 2003.

BURCH, Noel. Práxis do cinema. São Paulo: Perspectiva, 1992.

CAGE, John. Silence. Connecticut: Wesleyan University Press, 1961.

CAMPOS, Flavio de. Roteiro de Cinema e Televisão: A arte e a técnica de imaginar, perceber e narrar uma estória. Rio de Janeiro: Zahar, 2007. 
CANNITO, Nilton; SARAIVA, Leandro. Manual de roteiro. São Paulo: Conrad, 2004.

CARRIERE, J-C; BONITZER, P. Práctica del guión cinematográfico. Buenos Aires: Paidós, 1998.

CHION, Michel. L'audio-vision: son et image au cinéma. Paris: Editions Nathan, 1990.

CHION, Michel. Le son aucinéma. Paris: Cahiers du cinema, 1992.

CHION, Michel. La audiovisión. Barcelona: Paidós, 1993.

CHION, Michel. Audio-Vision: sound on screen. New York: Columbia University Press, 1994.

CHION, Michel. Como se escribe un guión. Tradução Dolores Jimenez. Madrid: Catedra, 2003.

Tradução de: Écrire un scenario, 1986.

CHION, Michel. David Lynch. Londres: The British Film Institute, 2006.

CHION, Michel. Film, a sound art. New York: Columbia University Press, 2009.

COEN, Joel; COEN, Ethan. Barton Fink. [S.1.] [199-?]. Disponível em:

<http://www.coenbrothers.net/scripts/bartonfink.pdf>. Acesso em 14 ago. 2016.

COMPARATO, Doc. Roteiro. Rio de Janeiro: Nórdica, 1983.

COSTA, Fernando Morais da; SÁ, Simone Pereira de (Org.). Som + imagem. Rio de Janeiro: 7 Letras, 2012.

DOANE, Mary Ann. A voz no cinema: a articulação de corpo e espaço. In: XAVIER, Ismail. A experiência do cinema. 2. ed. Rio de Janeiro: Graal, 1991. p. 457 -475.

DUBOIS, Philippe. Cinema, vídeo, Godard. São Paulo: CosacNaify, 2005.

EWALD FILHO, Rubens (Cord.). O Bandido da Luz Vermelha: argumento e roteiro de Rogério Sganzerla. São Paulo: Imprensa Oficial do Estado de São Paulo, 2008. 
EWALD FILHO, Rubens (Cord.). O céu de Suely: argumento de Simone Lima, Karim Aïnouz e Maurício Zacharias, Roteiro de Karim Aïnouz, Felipe Bragança e Maurício Zacharias. São Paulo: Imprensa Oficial do Estado de São Paulo, 2008.

FANO, Michel. Vers une dialectique du filmsonorein. Cahiers du Cinema, n. 152, p. 30-36, feb. 1964.

FANO, Michel . Le son, acteur de l'image. Nouveaux Dossiers de L'audio-Visuel, Nryr-surMarne, n. 3, jan./fev. 2005

FIELD, Syd. Manual do roteiro. Rio de Janeiro: Objetiva, 2001.

FLÔRES, Virgínia. O cinema: uma arte sonora. São Paulo, Annablume, 2013.

GORBMAN, Claudia (Ed.). Narrative film music. Indiana: Indiana University Graduate Theory Association, 1990.

HANEKE, Michael. Amour. [S.1.] [20--]. Diponível em: <http://www.sonyclassics.com/awardsinformation/amour_screenplay.pdf>. Acesso em: 14 ago. 2016.

KOZLOFF, Sarah. Invisible Storytellers: voice-over narration in American fiction film. Berkeley, CA: University of California Press, 1988.

LABRADA, Jeronimo. El Sentido del Sonido. Barcelona: Alba Editorial, 2008.

LABRADA, Jeronimo. Las películas siguen siendo mudas en una era sonora. Entrevista a Víctor Fowler Calzada e Dean Luis Reyes. Pausa, [Catalunha], n. 31, p. 103-121, [ 201-]. Disponível em: <http://www.salabeckett.cat/fitxers/pauses/pausa-31/entrevista-a-jeronimo-labrada> Acesso em: 18 ago. 2016.

LE FÈVRE-BERTHELOT, Anaïs. Audio-visual: disembodied voices in theory. InMedia [Online], n. 4, 2013. Disponível em: < http://inmedia.revues.org/697> Acesso em: 14 ago. 2016. LUMET, Sidney. Fazendo Filmes. Rio de Janeiro: Rocco, 1998.

MACHADO, Arlindo. Pré-cinema e pós-cinemas. Campinas: Papirus, 1997. 
MACHALSKI, Miguel. El guión cinematográfico: un viaje azaroso. Buenos Aires: Catálogo, 2006.

McKEE, Robert. Story. Curitiba: Arte e Letra, 2005.

MENDES, E. S. S. ; PINTO, I. Lucrecia Martel e o benefício da incerteza. Teorema-Crítica de Cinema, Porto Alegre, n. 8, p. 28-32, dez. 2005.

MENDES, E. S. S. Walter Murch: a revolução da trilha sonora cinematográfica. Significação: Revista de Cultura Audiovisual, v. 33, n. 26, p. 187-224, 2006.

MORAES, Ninho. Radiografia de um filme: São Paulo Sociedade Anônima. São Paulo: Imprensa Oficial, 2010.

MURCH, Walter. Entre la saturación y el silencio. In: CARRIERE. Jean-Claude et. al. Así de simple II . Madrid. Ollero \& Ramos, 1997. p. 185-211.

MURCH, Walter. Num piscar de olhos: a edição de filmes sob a ótica de um mestre. Rio de Janeiro: Jorge Zahar, 2004

NAGIB, Lucia. Going global: the Brazilian scripted film. In: HARVEY, S. (Ed.). Trading cultures: global traffic and local cultures in film and television. Eastleigh: John Libbey Publishing, 2007. p. 95-103.

ONDAATJE, Michel. The conversations: Walter Murch and the art of editing film. Nova York: Alfred A. Knopf, 2011

OPOLSKI, Débora. Introdução ao desenho de som: uma sistematização aplicada na análise do longa-metragem Ensaio sobre a cegueira. João Pessoa: Editora da UFPB, 2013.

PASOLINI, Pier Paolo. Le scénario comme structure tendant vers une autre structure. Paris, Cahiers du Cinéma, n. 185, p. 76-83, déc. 1966.

PASOLINI, Pier Paolo. Empirismo Herege. Tradução Miguel Serras Pereira. Lisboa: Assírio \& Alvim, 1982. 
PERCHERON, Daniel. Sound in Cinema and its relationship to image and diegesis. Yale French Studies, n. 60, . p16-23, 1980.

PLAZA, Julio. Tradução intersemiótica. São Paulo: Perspectiva, 2003.

ROJAS, Julio. Eliseo en 100 preguntas: el guión según Eliseo Altunaga. Ediciones Tripiofilms. Santiago, 2016.

ROSSIO, Terry. Script columns. California: Worldplay, 1997.

SAITTA, Carmelo. La banda sonora: apuntes para el diseño de la banda sonora en los lenguajes audiovisuales. La Fabrica Audiovisual: Universidade de Buenos Aires, 2002.

SANTAELLA, Lucia. Matrizes da linguagem e pensamento: sonora, visual, verbal. São Paulo: Fapesp/Iluminuras, 2001.

SCHAEFFER, Pierre. Le Contrepoint du son et de limage. Cahiers du Cinèma n. 108, p. 7-22, jun. 1960.

SEGER, Linda. Cómo convertir un buen guión en un guión excelente. Madri: Rialp, 1991.

SNIDER, Blake. Save the cat! The last book on screenwriting you'll ever need. California: Michael Wiese Productions, 2005.

THOM, Randy. Screenwriting for Sound. In: DEUTSCH, Stephen; POWER, Dominic; SIDER, Larry. (Ed.). The new soundtrack. Edimburgo: Edinburgh University Press, 2011.

TRAGTEMBERG, Livio. Contraponto: uma arte de compor. São Paulo: Edusp, 2002.

VALDÉS, Andrea. Lucrecia Martel: un pozo sin fundo. Elestadomental.com, Argentina.

Disponível em: < https://elestadomental.com/especiales/cavernicolas/lucrecia-martel-un-pozosin-fondo>. Acesso em 14 ago. 2016.

VALE, Eugène. Técnicas de guión para cine y televisión. Barcelona: Gedisa, 1996.

VANOYE, Francis. Guiones modelo y modelos de guión. Barcelona: Paidós, 1996. 
VIERS, Rick. The sound effects bible: how to create and record Hollywood style sound effects. California: Michael Wiese Productions, 2008. 